Pace University

DigitalCommons@Pace

2-6-2008

\title{
Perceptions of Fairness in Securities Arbitration: An Empirical Study
}

Jill I. Gross

Elisabeth Haub School of Law at Pace University

Follow this and additional works at: https://digitalcommons.pace.edu/lawfaculty

Part of the Dispute Resolution and Arbitration Commons, and the Securities Law Commons

\section{Recommended Citation}

Jill I. Gross \& Barbara Black, Perceptions of Fairness in Securities Arbitration: An Empirical Study (2008), http://digitalcommons.pace.edu/lawfaculty/478/.

This Article is brought to you for free and open access by the School of Law at DigitalCommons@Pace. It has been accepted for inclusion in Pace Law Faculty Publications by an authorized administrator of DigitalCommons@Pace. For more information, please contact dheller2@law.pace.edu. 


\title{
PerCePtions OF FAIRness OF
}

\section{SECURITIES ARBITRATION:}

\author{
AN EMPIRICAL STUDY
}

\section{REPORT TO THE SECURITIES INDUSTRY \\ CONFERENCE ON ARBITRATION}

\author{
February 6, 2008
}

\author{
JILL I. GROSS \\ Associate Professor of Law \\ Director, Investor Rights Clinic \\ Pace University School of Law \\ BARBARA BLACK \\ Charles Hartsock Professor of Law \\ Director, Corporate Law Center \\ University of Cincinnati College of Law
}




\title{
Perceptions of Fairness of Securities Arbitration: An EMPIrical Study ${ }^{1}$

\author{
FEBRUARY 6, 2008
} \\ REPORT TO THE SECURITIES INDUSTRY CONFERENCE ON ARBITRATION
}

\author{
Jill I. Gross ${ }^{2}$ \& Barbara Black $^{3}$
}

This Report to the Securities Industry Conference on Arbitration (SICA) documents the results of the authors' empirical study, through a one-time mailed survey, of survey participants' perceptions of fairness of securities Self-Regulatory Organization (SRO) arbitrations involving customers. ${ }^{4}$ The survey was designed to assess participants' perceptions of the: (1) fairness of the SRO arbitration process; (2) competence of arbitrators to resolve investors' disputes with their broker-dealers; (3) fairness of SRO arbitration as compared to their perceptions of fairness in securities litigation in similar disputes; and (4) fairness of the outcome of arbitrations.

\footnotetext{
${ }^{1}$ We would like to acknowledge Lisa DeBock, J.D., Pace '05, who provided invaluable research assistance for this study, Jared Ullman, J.D Candidate '09, Pace Law, and Nicklaus McKee, J.D. Candidate '09, Cincinnati Law, who assisted with data reports, and the administrative staff of Pace Law and the Investor Rights Clinic, who were enormously helpful to the authors in managing the survey mailing. We are grateful for the logistical assistance of Kenneth Andrichik, Senior Vice President and Director of Mediation and Business Strategies, FINRA Dispute Resolution, as well as his staff, for making this study possible.

${ }^{2}$ Associate Professor of Law and Director, Investor Rights Clinic (f/k/a/ Securities Arbitration Clinic), Pace University School of Law. A.B. Cornell; J.D. Harvard. Professor Gross has served as an NASD arbitrator, represented both customers and brokers in NASD and NYSE arbitrations, written and lectured extensively on securities arbitration, and been quoted in national media on the subject. A complete list of her publications related to securities arbitration is available at http://appserv.pace.edu/execute/page.cfm?doc_id=23171.

${ }^{3}$ Charles Hartsock Professor of Law and Director, Corporate Law Center, University of Cincinnati College of Law, B.A. Barnard; J.D. Columbia. Professor Black was the founder, and previously the Co-Director, of the Securities Arbitration Clinic at Pace University School of Law. She writes and lectures extensively on securities regulation, securities arbitration, and investors' rights; reports on current developments at Securities Law Prof Blog, http://lawprofessors.typepad.com/securities/; and is frequently quoted in the media. She also serves as a FINRA arbitrator. A complete list of her publications related to securities arbitration is available at http://www.law.uc.edu/faculty/black.shtml.

${ }^{4}$ For purposes of this study, SRO arbitrations include customer-initiated arbitrations at NASD Dispute Resolution and the New York Stock Exchange (NYSE) filed from January 1, 2002 through December 31, 2006 and closed between January 1, 2005 and December 31, 2006. See infra Part III. On July 30, 2007, National Association of Securities Dealers, Inc. (NASD) and NYSE Regulation, including their respective arbitration forums, consolidated, forming the Financial Industry Regulatory Authority (FINRA).
} 
Cornell University's Survey Research Institute (SRI), ${ }^{5}$ under the supervision of Director Yasamin Miller, processed 3,087 surveys, equaling a 13.0\% response rate. Thus, this survey gathered a large quantity of useful response data for analysis. ${ }^{6}$ We have confidence in our findings due to the following factors:

- We designed and administered the survey with a low error structure ${ }^{7}$

- A representative cross-section of target categories of arbitration participants responded to the survey; ${ }^{8}$

- Survey participants reflect a representative distribution of geographic regions; ${ }^{9}$ and

- Survey participants reflect a representative cross-section of arbitration participants based on the amount of the claim, the amount of damages awarded (if any), and the manner in which the case was resolved. ${ }^{10}$

Part I of this report provides an Executive Summary of our findings. Part II details the Background of the survey's development. Part III describes the Methodologies and Procedures we implemented to conduct the survey. Part IV identifies the Error Structure potentially contained in our methodologies. Part V contains our Findings as to each survey question, including, for many questions, breakdowns that isolate responses of customers only and compares them to all other categories of survey participants, as well as comparisons of regional differences among survey participants. We conclude in Part VI by noting the complexities of the findings. ${ }^{11}$

\footnotetext{
${ }^{5}$ Since 1996, SRI has been providing survey research, data collection, and analysis services to a wide-range of academic, non-profit, governmental, and corporate clientele. For more information on SRI, see http://www.cornellsurveyresearch.com/sri/index.cfm.

${ }^{6}$ See infra Part III.

${ }^{7}$ See infra Part IV.

${ }^{8}$ See infra Part V, Question 1.

${ }^{9}$ See infra Part V, Question 9.

${ }^{10}$ See infra Part V, Questions 10-12.

${ }^{11}$ This report provides some simple analyses of the data, but, due to time and resources, does not conduct the full range of multiple regression analysis that could be performed on the data.
} 


\section{I.}

\section{EXECUTIVE SUMMARY}

Survey participants have divided views about the fairness of securities arbitration, based on their most recent experience with the process. In general, when asked to focus on their most recent dispute filed for arbitration, participants overwhelmingly agreed that the arbitration panel listened to the parties, their representatives and the witnesses and gave the parties enough time to present their evidence and argue the merits of their cases. Participants also perceived that the arbitrators appeared competent to handle the dispute, to resolve pre-hearing issues, and to understand the issues and legal arguments in the case. They also believed that the discovery process allowed them to obtain the necessary information for a hearing.

In contrast, participants' perceptions as to other aspects of the panel's performance in their most recent dispute were more mixed; in particular, whether the panel was open-minded and impartial and whether the panel applied the law. Views were also divided on whether the hearings took too long and whether the arbitration process was too expensive. Survey participants were divided about whether they would recommend that others use arbitration to resolve their securities disputes; whether they had a favorable view of securities arbitration; and whether the outcome was very different from their initial expectations.

Furthermore, overall, participants were not satisfied with the outcome of their most recent dispute and would be more satisfied if they had an explanation of the award. Many survey participants with recent comparable experience in a civil court case perceived arbitration as unfair by comparison.

Finally, when asked about their overall perception of securities arbitration (as opposed to their perceptions derived from their most recent experience), survey participants were more negative. Although participants agreed that arbitration is conducted in a simple way, they were split as to whether the process is economical, and they disagreed with the statements that it is conducted without bias and conducted in a way that is fair to all parties.

For almost every question in the survey, statistical analysis reveals that customers have a more negative perception of the process than non-customers, as we detail throughout the report. 
II.

\section{BACKGROUND}

The Perino Report. The impetus for this study was Professor Michael Perino's

November 4, 2002 report to the Securities and Exchange Commission (SEC) regarding arbitrator disclosure requirements in securities arbitration. ${ }^{12}$ The SEC requested that Professor Perino investigate whether the current SRO arbitrator conflict disclosure rules undermined investors' perceptions about the fairness of securities arbitration. ${ }^{13}$ In the resulting report, Professor Perino wrote that he found that the disclosure rules appeared to be adequate and noted that any "lingering perceptions of pro-industry bias" relate to "panel composition, not the presence of undisclosed arbitrator conflicts." ${ }^{\prime 4}$ The Perino Report also noted that, while empirical evidence was limited, past surveys seemed to suggest that parties involved in SRO arbitrations find that arbitrators are fair and impartial. ${ }^{15}$ However, because of "lingering concerns about pro-industry bias" and the insufficient amount of empirical evidence addressing investors' perceptions of the securities arbitration process, Professor Perino recommended that the "SROs sponsor additional independent studies to further evaluate the impartiality of the SRO arbitration process." 16

Other Empirical Studies. Since the Perino Report, only a few researchers have conducted empirical studies of securities arbitration, and none of them focuses on perceptions of fairness. ${ }^{17}$

\footnotetext{
${ }^{12}$ See Michael Perino, Report to the Securities and Exchange Commission Regarding Arbitrator Conflict Disclosure Requirements in NASD and NYSE Securities Arbitration (Nov. 4, 2002), available at http://www.sec.gov/pdf/arbconflict.pdf [hereinafter Perino Report].

${ }^{13} I d$. at 3.

${ }^{14} I d$.

${ }^{15} I d$. at 30. The Perino Report primarily was referring to two GAO studies (see Securities Arbitration: How Investors Fare, GEN. ACCT. OFF., REP. NO. GGD-92-71 (1992) (finding that statistical results from industrysponsored and independent forums did not show any indication of a pro-industry bias in arbitration decisions at industry-sponsored forums); Securities Arbitration: Actions Needed to Address Problem of Unpaid Award, GEN. ACCT. OFF., REP. NO. GGD-00-115 (2000) (stating that there was no basis to make any conclusions about the fairness of SRO arbitration proceedings, because the small caseloads at alternative forums did not allow for meaningful comparisons)), and NASD's Tidwell Report (see Gary Tidwell, Kevin Foster \& Michael Hummel, Party Evaluations of Arbitrators: An Analysis of Data Collected from NASD Regulation Arbitrations (Aug. 5, 1999), available at http://www.finra.org/web/groups/med_arb/documents/mediation_arbitration/p009528.pdf (concluding that both parties to the arbitration process found arbitrators, and the process itself, to be fair and unbiased)).

${ }^{16} I d$. at 37.

${ }^{17}$ There are also empirical studies that focus on other forms of arbitration. One that deals specifically with perceptions is Harris Interactive Survey, Arbitration: Simpler, Cheaper, and Faster Than Litigation (Apr. 2005), at http://www.instituteforlegalreform.com/issues/docload.cfm?docld=489 (conducted on behalf of the U.S. Chamber of
} 
Three examine arbitration outcomes. First, Empirical Evidence of Worsening Conditions for the Investor in Securities Arbitration, ${ }^{18}$ a 2002 report, concluded that conditions have worsened over time for investors: their success rate has declined, brokers are more likely to prevail on their counterclaims, and repeat players have a competitive advantage. Second, a 2007 study entitled Mandatory Arbitration of Securities Disputes: A Statistical Analysis of How Claimants Fare 19 analyzed SRO awards from 1995-2004. Its findings include: (1) claimant win rates have declined since 1999, (2) claimant win rates are lower against larger brokerage firms, (3) awards as a percent of amount claimed have declined since 1998, and (4) the larger the case, the lower the award as a percent of the amount claimed. Third, in 2007, the Securities Arbitration Commentator completed a two-part survey of SRO awards, in which it compared results in 2005 to 2000-04 results. ${ }^{20}$ Its findings include: (1) a decline in customer win rates from 53\% in 2001 to $43 \%$ in 2005 and (2) a decline in customer median recovery rates (median award/median compensation claimed) from $47 \%$ in 2000 to $34 \%$ in 2005.

Two empirical studies focus on the arbitrators. Three law professors released in 2008 a working paper that examined the role of attorneys as arbitrators. Attorneys as Arbitrators ${ }^{21}$ examined a dataset of 422 randomly selected attorney-arbitrators and their 6724 awards from 1992-2006 and found that arbitrators who also represent brokerage firms or brokers in other arbitrations award significantly less compensation to investor-claimants than other arbitrators. In contrast, they found no significant effect for attorney-arbitrators who represent investors or both investors and brokerage firms. They also concluded that the 1998 NASD reforms to the selection process ameliorated, but did not eliminate, the effect of attorneys who represent the securities industry. Another academic working paper, Self-Regulation and Enforcement in

Commerce Institute for Legal Reform, this survey interviewed 609 individuals and found general satisfaction with arbitration).

1812 SeCURities ARbitration COMmentator 7 (June 2002). The study was conducted by Richard A. Voytas, Jr.

${ }^{19}$ The report was authored by Edward S. O’Neal, Securities Litigation and Consulting Group, and Daniel R. Solin, a securities arbitration attorney representing investors, and is available at http://www.smartestinvestmentbook.com/ or http://www.slcg.com/.

202006 Securities Arbitration Commentator 1, No. $7 \& 8$ (Feb. 2007), 2006 SeCURITIES Arbitration COMMENTATOR 1, No. 2 (Apr. 2006).

${ }^{21}$ The paper is authored by Stephen J. Choi, Jill E. Fisch, and A.C. Pritchard and is available at http://www.ssrn.com/abstract=1086372. 
Financial Markets: Evidence from Investor-Broker Disputes at the $N A S D,{ }^{22}$ examined data from January 1991 through December 2004 and found that arbitrators who are pro-industry or have more expertise are selected more often, particularly when the cases are important to the industry or are more complex, respectively. In addition, after NASD rules were amended to remove the organization's control over the selection process, the selection of pro-industry arbitrators increased, while the selection of arbitrators with more expertise decreased.

Finally, one paper examined several aspects of the arbitration process. In 2007, the Securities Industry and Financial Markets Association released a "white paper" that includes findings that arbitration is faster than litigation and that the presence of an industry arbitrator has no material impact on customer wins. ${ }^{23}$

The Importance of Perceptions of Fairness. Academic literature confirms the importance of surveying perceptions of fairness of a dispute resolution forum. ${ }^{24}$ These perceptions are important because the substantive (or distributive) fairness of a dispute resolution process ${ }^{25}$ can not readily be measured, especially when the process is confidential and outcomes are not transparent (as they are in securities arbitration when awards do not typically contain an explanation or reasons).

Dispute resolution scholars recently have focused on procedural justice as a more reliable predictor than substantive justice with respect to parties' assessment of the overall fairness of a process. $^{26}$ These scholars have found that perceptions of procedural fairness strongly impact

\footnotetext{
${ }^{22}$ The paper is authored by Jiro E. Kondo, a Ph.D candidate at MIT Sloan School of Management, bears the date of November 2006 and is available at http://web.mit.edu/jekondo/www/jobmkt_paper.pdf.

${ }^{23}$ Securities Industry and Financial Markets Association, White Paper on Arbitration in the Securities Industry (2007), available at http://www.sifma.org/regulatory/pdf/arbitration-white-paper.pdf.

${ }^{24}$ See, e.g., Jean R. Sternlight, ADR Is Here: Preliminary Reflections on Where It Fits In A System of Justice, 3 NEV. L. J. 289, 297-98 (2003) [hereinafter ADR Is Here] (stating that the "subjective perception of fairness is critical, because even assuming objective fairness, the system could not function well if it were perceived to be unfair or unjust").

${ }^{25}$ A process is substantively fair if equally situated disputants receive equal outcomes. See Jean R. Sternlight, Creeping Mandatory Arbitration: Is It Just?, 15 STAN. L. REV. 1637, 1666 (2005) [hereinafter, Creeping Mandatory Arbitration] (defining substantive, or distributive, justice and stating that "if a single party or group were to win all disputes, if equally situated persons received disparate results, or if the 'justice' system led to increasingly unequal division of resources, few if any of us would feel that justice had been served").

${ }^{26}$ See Lawrence B. Solum, Procedural Justice, 78 S.CAL. L. REV. 181 (2004) (theorizing importance of procedural justice for legitimacy of dispute resolution processes); Sternlight, ADR Is Here, supra note 24, at 297.
} 
perceptions of substantive fairness, which results in a greater willingness to comply with the outcome and greater trust in and respect for the decision-maker. ${ }^{27}$ Summarizing prior research by social psychologists, a leading scholar of procedural justice writes that "people who believe that they have been treated in a procedurally fair manner are more likely to conclude that the resulting outcome is substantively fair, even if that outcome is unfavorable." ${ }^{28}$ She posits that four key elements "reliably lead people to conclude that a dispute resolution process is procedurally fair": (1) the process provides an opportunity for disputants to voice their concerns to a third party; (2) the disputants perceive that the third party actually considered these concerns; (3) the disputants perceive that the third party treated them in an "even-handed" way; and (4) the disputants feel that they were treated in a dignified and respectful manner. ${ }^{29}$ Thus, by asking survey participants post hoc about their most recent experience with the SRO arbitration process, including their perceptions about whether the arbitrators listened to their case, the competence and impartiality of the arbitrators, as well as their satisfaction with the outcome, we gain valuable insights about procedural and substantive fairness in securities arbitration cases as experienced by the survey participants.

SICA Commissions the Study. In April 2003, SICA discussed Professor Perino's recommendation to sponsor an independent study. On October 5, 2003, SICA disseminated a Request for Proposal (RFP) seeking vendors interested in conducting the recommended study. We submitted a proposal in response to this RFP on November 3, 2003. At its January 2004

\footnotetext{
${ }^{27}$ Susan Franck, Integrating Investment Treaty Conflict and Dispute System Design, 92 MINN. L. REV. 161, 214-15 (2007) ("Empirical evidence suggests that when stakeholders believe a system is procedurally just, they are more likely to buy into the result and the process, comply with the outcome, comply with the law in the future, increase commitment to the organization, accord respect and loyalty to the institution, and perceive the system to be legitimate."); Nancy Welsh, Perceptions of Fairness, in THE NeGOTIATOR's FIELDBOOK 165, 170 (Andrea K. Schneider \& Christopher Honeyman eds., 2006); Deborah R. Hensler, Judging Arbitration: The Findings of Procedural Justice Research, in AAA HANDBOOK ON COMMERCIAL ARBITRATION 41-49 (Thomas E. Carbonneau \& Jeanette A. Jaeggi eds., 2006); Sternlight, Creeping Mandatory Arbitration, supra note 25, at 1666-67 (citing studies).

${ }^{28}$ Welsh, supra note 27, at 170; see also Hensler, supra note 27, at 48 (stating that "arbitration litigants will be satisfied with arbitration if they think the process is fair and will be dissatisfied if they think the process is unfair").

${ }^{29}$ Nancy A. Welsh, Remembering the Role of Justice in Resolution: Insights from Procedural and Social Justice Theories, 54 J. Legal ED. 49, 52 (2004) (citing Nancy A. Welsh, Making Deals in Court-Connected Mediation: What's Justice Got to Do With It?, 79 WASH. U. L. Q. 787 (2001)); see also Hensler, supra note 27, at 48 (concluding that "any assessments of the procedural fairness of arbitration by arbitration litigants will depend on several variables: whether they are allowed to participate in, or at least observe, the process firsthand; and whether they believe the arbitrator is unbiased, gave fair consideration to their evidence, treated all parties equally, and treated them in a dignified fashion").
} 
meeting, SICA convened a task force to review the proposals and make a recommendation on moving forward. That task force met several times and submitted its recommendation to SICA at its June 8, 2004 meeting.

On July 22, 2004, SICA issued a revised RFP to the vendors who had previously submitted proposals. We submitted a revised proposal on October 7, 2004. As suggested in the Perino Report, we proposed to design a survey to investigate the fairness of SRO arbitrations to the individual investor, focusing on an assessment of (1) investors' perceptions of fairness of the SRO arbitration process; (2) whether arbitrators appear competent to resolve investors' disputes with their broker-dealers; (3) investors' perceptions of fairness of SRO arbitration as compared to their perceptions of fairness in securities litigation in similar disputes; and (4) whether the outcome of arbitrations appears fair to the parties. SICA accepted this proposal via e-mail on November 24, 2004. We received the first payment confirming acceptance of the proposal in the spring of 2005. Following extensive discussions and negotiations among counsel for the respective parties, NASD and NYSE Group, as members of SICA, entered into an Agreement for Services with Pace University, effective as of August 22, 2005, formally retaining us to conduct the recommended study. 


\section{III.}

\section{Methodologies AND Procedures}

Survey Development and Design. Starting in November 2004, we began to identify areas in which to develop questions for the survey. We researched the regulatory oversight of securities arbitration to determine the aspects of the process that should be targeted in survey questions. We canvassed recent media coverage to identify concerns raised by the public. We reviewed prior survey instruments used by researchers studying securities and other forms of arbitration, as well as other fields. We also took into account the four elements of procedural fairness in the design of the survey questions.

In May 2005, we retained the services of SRI to provide us with survey design and implementation expertise. First, in consultation with SRI and SICA, we decided what type of survey to implement. We concluded that we would not be able to implement an internet-based survey, primarily because the two forums did not maintain a sufficiently complete database of email addresses to make this possible and because some parties, particularly elderly investors of modest means, might not have access to a computer. Additionally, the forums did not maintain a complete database of telephone numbers for a telephone survey. Thus, we concluded that the most effective way to gather comprehensive and scientifically accurate responses would be to develop and disseminate a paper survey by mail. Mail surveys also offer the following advantages: (1) they require fewer resources than telephone surveys; (2) they provide a sense of privacy to the survey participant; and (3) they are less sensitive to bias introduced by interviewers. We considered and weighted these advantages against some disadvantages: (1) risk of noncoverage error (i.e., the database of recipients is flawed); (2) risk of nonresponse error (i.e., those who respond are different from those who do not respond in a substantive way that affects the survey results); (3) lack of control over who within the household responds; and (4) risk that survey participants may not fill out the questionnaire completely.

Second, with SRI's input, we drafted questions for the mail survey. Our drafting goals included: designing a survey that could yield scientifically accurate and useful data, stripping any suggestion of bias from individual questions as well as from the survey as a whole, covering key issues surrounding securities arbitration, retaining the ability to survey multiple role players in securities arbitration and maintaining a logical flow embedded in the order of questions 
depending on the role of the participant. ${ }^{30}$ We included four types of questions: (1) questions requiring a binary response (e.g., "yes" or "no"), (2) categorical questions (requiring a response from a list of viable options), (3) Likert scale questions (statements that could be answered by a range of responses, such as strongly agree, agree, neither agree nor disagree, disagree, strongly disagree, don't know), and (4) one open-ended question - the state in which a hearing was scheduled to take place - to study any possible variations among geographic regions.

Within the statement section, we varied the orientation of the statements to include both negative and positive statements. For example, question 16 asked survey participants to agree or disagree with the statement: "The arbitration panel appeared competent to resolve the dispute." In contrast, question 17 asked survey participants to agree or disagree with the statement: "The arbitration panel did not understand the issues involved in the case." This type of contrast helps to ensure that the participants were paying attention to the statements and also maintains the neutrality of the survey. With respect to subjective questions, we instructed survey participants who had been involved in more than one customer dispute that was filed for arbitration to focus on the most recent one, to minimize survey participants' reliance on more generalized impressions that can yield unreliable data that is subject to recall bias. ${ }^{31}$

In July 2005, we generated a "beta" or test version of the survey to ensure that the survey flow was logical, the questions were worded in a comprehensible manner and there was no perceived bias. We administered the test version to approximately fifteen potential survey recipients, including investors who had participated in recent arbitration cases, lawyers who had represented both customers and brokers in recent arbitrations, and former law students who had participated in Pace Law's Securities Arbitration Clinic. The “testers" provided useful

\footnotetext{
${ }^{30}$ While our initial proposal contemplated surveying investors only, SICA instructed us to survey all process participants, including investors, securities industry representatives, and lawyers.

${ }^{31}$ Research around memory bias reveals that personal recall of retrospective questions is a function of past and present experiences. The typical finding is that people exaggerate the consistency between their present (new) attitudes and their past opinions. Furthermore, people tend to bias their memories of previously held attributes in ways that deny changes that have actually taken place or overstate them. The literature concludes that there are two forms of systematic bias in personal memories: 1) people will exaggerate their consistency over time and incorrectly recall events, tending to recall past events consistent with current events, or 2) people will overestimate the extent to which their past memories differ from current experiences (sometimes a prominent/extreme event occurred in the past overshadows all other events in the past). See J.M. Tanur, QuESTIONS ABOUT QuESTIONS (Russell Sage Foundation, 1991); see also LinChiat Chang \& Jon A. Krosnick, Measuring the Frequency of Regular Behaviors: Comparing the "Typical Week" to the "Past Week," 33 SociologiCAl Methodology 55 (2003); S. Sudman \& N.M. Bradburn, RESPONSE EFFECTS IN SURVEYS (Aldine 1974).
} 
comments and suggestions, and we further revised the questions. We submitted the beta-tested survey instrument to SICA in August 2005. Following a review and discussion period with SICA members, including our attendance at two SICA meetings in January and June 2006, we further revised the survey.

During this time period, SICA expressed a primary concern regarding our focus on gathering survey participants' answers based on their most recent experience in an SRO arbitration rather than their impressions based on numerous experiences. We explained to SICA that it was important to minimize "recall bias" (the ability of people to accurately recall details of events diminishes as the time since the event increases) by avoiding asking people about their impressions. ${ }^{32}$ Also, we wanted this study, to the extent possible, to gather "information" rather than "impressions," as impressions are influenced or confounded by other factors for which a survey instrument cannot accurately control. Moreover, the law of averages shows that a "terrible" recent experience reported by one survey participant will smooth out against a "great" recent experience reported by another survey participant. It was our view that survey data would be far more reliable and scientifically accurate if we directed survey participants to focus on their most recent experience. Thus, based on SRI's advice, we recommended designing the survey to ask participants to answer the questions based on their most recent experience, and SICA ultimately agreed with our recommendation.

At its June 2006 meeting, SICA decided that we would not conduct telephone interviews of those survey participants who indicated a willingness to be interviewed. ${ }^{33}$ SICA approved the survey content in July 2006. We then submitted the content to SRI, who designed and formatted the final document. We beta-tested this version of the designed survey on law student Fellows at the University of Cincinnati College of Law's Corporate Law Center. SICA subsequently approved the survey as designed, as well as the cover letter, outgoing and return envelope. ${ }^{34}$

Starting in February 2007, NASD and NYSE collated and packaged the cover letter, survey and a pre-addressed, postage-paid envelope for survey participants to return the survey to

\footnotetext{
${ }^{32}$ For a more detailed description of "recall bias," see supra note 31.

${ }^{33}$ Nevertheless, numerous survey recipients telephoned SRI and/or the Pace Investor Rights Clinic to voice their views about the subject matter of the survey. Callers were told that the surveyors could not accept comments over the phone, but that they could write comments on the surveys themselves if they so chose. We have reviewed and retained these written comments, but have not incorporated them into the report.

${ }^{34}$ See Appendix A for the final survey and accompanying cover letter.
} 
SRI. Pace mailed out the survey between March and July 2007. SRI received and processed results from April to August 2007. This report reflects data collected through August 31, 2007.

Survey Recipients. Simultaneously with survey development, we identified the parameters of the target survey recipients. After conversations with both NASD Dispute Resolution and NYSE Arbitration, we determined that those forums could generate a database of all parties and their representatives who had participated in a customer-member arbitration and had provided their contact information for a number of past years. Our objective was to generate contacts from two years of recently closed cases, which we estimated to be a manageable and representative population, but exclude cases that were filed earlier than five years ago and thus were administered before numerous rule changes went into effect.

After extensive discussions, and with the approval of SICA, we determined that we would send out surveys to the following subset of individuals:

Contacts listed for all customer arbitrations filed at NASD and NYSE not earlier than January 1, 2002 and closed between January 1, 2005 and December 31, 2006;

(1) Including contacts that were: on the case when it closed, removed due to a bankruptcy order or other court order, or dismissed by arbitrator(s); and

(2) Excluding contacts from cases in which the initial pleading was not served (e.g., cases that were closed before service because a deficiency was not cured).

NASD and NYSE generated a combined database of 29,993 contacts to participate in the survey. Of those contacts, 4,710 surveys were either returned to SRI or otherwise not deliverable due to insufficient address. Thus, we effectively mailed out a total of 25,283 surveys. We subsequently determined that at least 1500 of those contacts were duplicates. Thus, at most, 23,783 contacts had the opportunity to participate in the survey. Through August 31, 2007, when data collection closed, SRI received and processed 3,087 responses. This reflects a thirteen percent $(13.0 \%)$ response rate based on those surveys effectively mailed out to a contact, which is in line with typical response rates obtained from a one-time mailing of a survey (response rates for a one-time mailing range from eight to twelve percent). ${ }^{35}$ In mid-September 2007, we received a preliminary codebook from SRI, and on October 1, 2007, we received the final codebook containing all data processed by SRI from returned surveys.

\footnotetext{
${ }^{35}$ This range is derived from SRI's experience over twenty years as well as the experience of other prominent survey research organizations.
} 


\section{IV.}

\section{ERror STRUCTURE}

It is widely recognized that several sources of error can impact the quality of survey data. This survey is subject to two possible sources of error: coverage error and nonresponse error.

Coverage error. This survey is subject to some coverage error, or the risk that the results are not reliable because not all members of the population (NASD or NYSE arbitration participants during a five-year time period) have an equal chance of being surveyed.

At the outset, we designed parameters for selecting a population of cases that originated on or after January 1, 2002 (but eliminating arbitration participants in cases that had not yet closed). This ensured that the survey participants proceeded under substantially the same arbitration rules in their most recent dispute. The contacts database generated by our parameters was incomplete because the forums do not require the parties to provide an address if they have a representative. Therefore, many party addresses were missing or otherwise undeliverable. In addition, the database contained duplications for several reasons. First, entries for certain contacts appeared multiple times if the data entered was just slightly different. The difference could be something as simple as a period, space, or could be a completely different address. While the forums electronically reviewed the database to minimize the duplicates, they could not ensure that no contact received a duplicate survey. ${ }^{36}$ Second, if a firm and one of its subsidiaries were listed as parties, the forums could not limit the database to just the firm, resulting in certain firms with multiple listings. Third, in situations where there were multiple parties with similar names and the same address, there were multiple rows in the report. An example might be an individual, an IRA and a Trust all entered as separate parties. As a result, lawyers, firms and associated persons in the database were more likely to receive a survey than customers.

Nonresponse bias. Nonresponse bias is the risk that those who responded may be different in their answers to the survey questions from those who did not respond to the survey. Because $13.0 \%$ of those who received a survey actually responded, our findings are potentially limited by this nonresponse error.

The preferred method to test whether nonresponse bias exists in survey data is to conduct telephone interviews of a random sample of contacts who did not respond to measure whether their answers to the survey questions are statistically significantly different from the survey

\footnotetext{
${ }^{36}$ As noted above, there were at least 1500 duplicates.
} 
participants. While we recommended conducting such a follow-up study, due to time and resource constraints, SICA did not endorse that recommendation. As a result, we cannot state with certainty whether there is, in fact, any nonresponse bias in the survey data.

However, recent survey literature indicates that low response rates do not necessarily lead to high nonresponse bias. ${ }^{37}$ At a recent national workshop on nonresponse bias, Robert $\mathrm{M}$. Groves, Professor of Sociology and Director of the Survey Research Center at the University of Michigan and a leading scholar of survey research, argued that "a narrow focus on response rates has likely been leading researchers astray from the more fundamental driver of non-response bias - a relationship between the propensity of a household to respond and the value of that household on a given survey measure." 38 Groves used a meta-analysis of nonresponse studies to provide empirical support for this argument. Among his main conclusions are that (1) "response rate is a poor indicator of non-response bias," and (2) more variation in nonresponse bias exists within surveys (between different estimates) than exists between surveys with higher or lower response rates. $^{39}$

\footnotetext{
${ }^{37}$ See, e.g., Robert M. Groves, Nonresponse Rates and Nonresponse Bias in Household Surveys, PUBLIC OPINION QUARTERLY, Vol. 70, No. 5, Special Issue 2006, at 646-675 (stating that "there is little empirical support for the notion that low response rate surveys de facto produce estimates with high nonresponse bias"); John Rogers, Ph.D, Do Response Rates Matter in RDD Telephone Survey?, Public Research Institute, Theory and Method, at http://pri.sfsu.edu/corner.html (Nov. 13, 2006) ("The continued development of research on nonresponse bias provides comforting news in that RDD surveys can still provide surprisingly accurate and reliable estimates even in an era of declining response rates. But this same research also carries a warning that in some situations our estimates can be biased in important ways by nonresponse.").

${ }^{38}$ See American Association of Public Opinion Research, D.C. Chapter, Report on Workshop on Nonresponse Bias in Household Surveys (Mar. 30, 2007), at 8.

${ }^{39} I d$. (italics in original). At the workshop, Groves remarked: "I must admit for me this was a shocker the first time I saw it. This sort of rocks your belief system if you've been training students for the last 30 years that high response rates are really a good thing because it protects you from nonresponse bias." Id.
} 


\section{FINDINGS}

3087 survey participants mailed completed surveys back to SRI. Through text, pie charts and bar charts, we report below numerical results of the survey for all 38 questions and their subparts. The charts present data from SRI's codebook in an easily readable format and facilitate comparisons of data. Additionally, when we report a percentage of survey participants, this figure reflects the percentage of "valid" survey participants, or the percentage of those survey participants who answered that question.

With the assistance of SRI, we analyzed the data to identify any statistically significant differences (at the $5 \%$ level) ${ }^{40}$ in responses among categories of survey participant, sorted by both type of survey participant (Question 1 categories) and, for some questions, region of survey participant (Question 9 categories). Throughout this section, we note where analysis revealed a statistically significant difference between survey participant type (customers vs. everyone else) and among the regions of survey participants (Northeast, Southeast, Midwest and West).

\section{A. Survey participant type}

The first five questions and their subparts focused on categorizing the survey participants and quantifying the level of survey participants' involvement in securities arbitrations over the past five years. Question 1 asked survey participants to identify the nature of their involvement "in a dispute between a customer and a securities brokerage firm and/or its registered representative(s) ('associated person(s)') that was filed for arbitration before NASD or the NYSE." The survey participants identified themselves as follows:

\footnotetext{
${ }^{40}$ We used the Chi-square test of association, which tests the null hypothesis that there is no association between the row and column variables. A p-value of <.05 (less than 5\%) rejects the null hypothesis and supports the conclusion that there is an association between the row and column variables.
} 


\begin{tabular}{|l|l|l|}
\hline Q1: Nature of Involvement & $\begin{array}{l}\text { Number of survey } \\
\text { participants who } \\
\text { selected this response }\end{array}$ & $\begin{array}{l}\text { Percentage of survey participants } \\
\text { who answered this question }\end{array}$ \\
\hline $\begin{array}{l}\text { Customers } \\
\begin{array}{l}\text { Corporate representatives (of } \\
\text { member firms) }\end{array}\end{array}$ & 202 & 45.1 \\
\hline $\begin{array}{l}\text { Associated persons } \\
\begin{array}{l}\text { Lawyer/other party } \\
\text { representative }\end{array}\end{array}$ & 460 & 6.7 \\
\hline $\begin{array}{l}\text { Not involved in any such } \\
\text { dispute }\end{array}$ & 926 & 15.3 \\
\hline
\end{tabular}

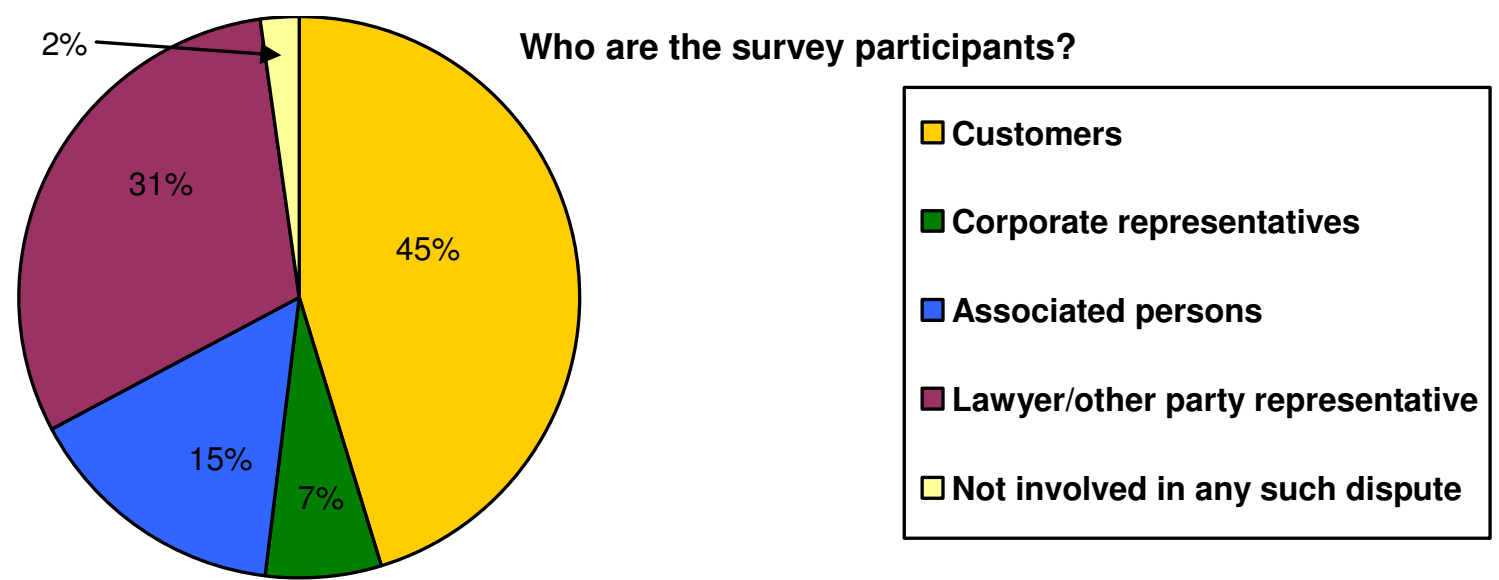

Thus, the largest number of survey participants were customers $(1359$, or $45.1 \%$ of those who identified their role), followed by lawyers/other party representatives (926, or 30.8\%).

This analysis of the distribution of type of survey participant led us to consider weighting the responses based on this distribution as compared to the distribution of type of contact in the mailing database. To ensure that a category of survey participants does not have the opportunity to have its opinion counted disproportionally, accepted practice for survey researchers is to apply post-stratified population weights to survey answers so as to adjust the impact of a participant category on the overall answer for each question. However, researchers apply these weights only

\footnotetext{
${ }^{41}$ These 63 survey participants who answered that they were not involved in a customer arbitration in the past five years were excluded from the remaining survey questions. Thus, totals of valid survey participants for other categories could be no more than 3024 (3087-63).
} 
if they have accurate classifications of both the contacts in the mailing database and survey participants. $^{42}$

Thus, we attempted to compare the classification distributions of survey participants to the classification distributions of contacts in the mailing database: ${ }^{43}$

\begin{tabular}{|c|c|c||}
\hline $\begin{array}{c}\text { CATEGORY OF } \\
\text { CONTACT }\end{array}$ & $\begin{array}{c}\text { PERCENTAGE OF } \\
\text { CONTACTS IN } \\
\text { DATABASE }\end{array}$ & $\begin{array}{c}\text { PERCENTAGE OF } \\
\text { SURVEY } \\
\text { PARTICIPANTS }\end{array}$ \\
\hline Customers & $33 \%$ & $45 \%$ \\
\hline Lawyers/representatives & $37 \%$ & $31 \%$ \\
\hline Associated persons & $23 \%$ & $15 \%$ \\
\hline $\begin{array}{c}\text { Corporate representatives } \\
\text { of member firms) }\end{array}$ & $5 \%$ & $7 \%$ \\
\hline
\end{tabular}

We concluded that we do not have sufficient confidence in the accuracy of these classification percentages to justify weighting. We do not have confidence because:

- FINRA has provided us with classifications for $97.5 \%$ of the contacts in the database (756 records, or $2.5 \%$ of the 29,850 total contacts, could not be classified according to the categories we used). Thus, we cannot classify $2.5 \%$ of the contacts.

- We examined the detail of 1,570 NYSE records (99.6\% of which were lawyers) and 9445 NASD records (100\% of which were lawyers) in the contacts database. Of those combined records, at least 1500 are duplicates. Experience shows that participants do not fill out more than one survey, so lawyers as a classification are over-represented in the contacts database percentage by at least $5 \%$.

- 77 survey participants, representing $2.5 \%$ of the 3024 valid survey participants, did not answer question one, but did answer other survey questions. Thus, we cannot classify $2.5 \%$ of the survey participants.

Despite our lack of confidence in the weighting percentages to be applied, we tested the weights by assuming the percentages as provided are accurate. We applied those weights to six questions $(19,34,38 \mathrm{a}, 38 \mathrm{~b}, 38 \mathrm{c}$, and 38d). With respect to the overall data, the weighted results showed only a marginal difference in the responses [slightly more positive perceptions], and no trends or observations would be changed. With respect to the analysis of customer vs. everyone

\footnotetext{
${ }^{42}$ See, e.g., Weighting for Unequal $\mathrm{P}_{\mathrm{i}}, 8$ Journal OF OfFicial Statistics 183 (1992).

${ }^{43}$ FINRA, the entity that maintained the mailing database, categorized the contacts database.
} 
else data, the customer numbers are unchanged; the "everyone else" numbers are changed less than half of one-percent in every case except one. In sum, even if we were to apply the most extreme weights we could envision applying, there would be no substantial change in the overall results. $^{44}$

Question 2 asked parties to a dispute whether they were represented by a lawyer in that dispute. $81.7 \%(1,650)$ of those who identified themselves as a party to an arbitration proceeding and who chose to answer the question reported that they were represented by a lawyer. Of the remaining parties who chose to answer:

○ $0.3 \%$ (6) were represented by a lawyer through a law school clinic;

○ $1.7 \%$ (35) were represented by a non-lawyer; and

○ $16.2 \%$ (328) represented themselves, either because:

- $\quad$ they did not want to be represented [5.4\%],

- $\quad$ they could not afford a lawyer [8.6\%], or

- $\quad$ they could not find a lawyer [2.2\%].

The survey directed only lawyers or party representatives to answer questions 3 and 4, which asked about the nature of their representation in the past five years. Of the 902 lawyers/representatives who answered question 3, $14.3 \%$ (129) reported being involved in only one dispute. In that one dispute, 94 represented the customer, 27 represented the brokerage firm and 24 represented the associated person. ${ }^{45}$ In contrast, $85.7 \%$ (773) of the 902 lawyers/representatives who answered were involved in more than one dispute. Of the 732 responses to question 4a, which asked whom the lawyer primarily represented in the past five years, $48.1 \%$ (352) primarily represented customers, $46.6 \%$ (341) primarily represented firms, and 4.6\% (34) primarily represented associated persons. ${ }^{46}$ Question $\mathbf{4 b}$ asked whom they represented in the most recent dispute: $44.4 \%$ (354) represented the customer; $44.2 \%$ (352) represented the firm; and $22.8 \%$ (182) represented the associated person. ${ }^{47}$

\footnotetext{
${ }^{44}$ The results from the test run of weighted survey participant classifications for questions $19,34,38 \mathrm{a}, 38 \mathrm{~b}, 38 \mathrm{c}$, and 38d is Appendix B to this report.

${ }^{45}$ The question instructed survey participants to select all that applied, so the total exceeds the number of survey participants.

${ }^{46}$ Five answered "do not know/do not recall."

${ }^{47}$ The sum of these percentages is more than $100 \%$ because some lawyers answered this question that they represented both the firm and the associated person.
} 
Question 5 asked all parties as well as lawyers/representatives involved in more than one dispute to provide the number of disputes in which they have been involved in the past five years. $58.8 \%(1,510)$ of these survey participants $(2,570)$ have been involved in only one dispute. $75 \%$ of the survey participants who were involved in only one dispute who also answered question one identified themselves as customers (1115 out of 1495). The breakdowns are as follows:

\begin{tabular}{|c|c|c|}
\hline $\begin{array}{c}\text { Q5: Number of disputes } \\
\text { involved in - past five years }\end{array}$ & $\begin{array}{c}\text { Number of survey } \\
\text { participants who } \\
\text { selected this response }\end{array}$ & $\begin{array}{c}\text { Percentage of survey } \\
\text { participants who } \\
\text { answered this } \\
\text { question }\end{array}$ \\
\hline One & 1,510 & 58.8 \\
\hline $2-5$ & 392 & 15.3 \\
$6-10$ & 119 & 4.6 \\
\hline More than 10 & 546 & 21.2 \\
Do not know & 3 & 0.1 \\
\hline
\end{tabular}

\section{B. Pre-dispute arbitration clause}

Questions 6 through 11 asked all survey participants a series of questions about their most recent dispute. Question 6 focused on the pre-dispute arbitration clause (PDAA). Of the 2,841 responses, $79.3 \%$ of survey participants $(2,252)$ answered question $6(\mathbf{a})$ that the customer agreement in the most recent dispute contained a PDAA. $7.3 \%$ of survey participants (208) answered that the customer agreement did not contain a PDAA, suggesting that PDAAs in brokerage firm agreements are prevalent, but not universal. 13.4\% (381) of survey participants did not know or could not recall whether the customer agreement contained such a clause.

Question 6(b) focused on the participants' awareness of the PDAA before the dispute arose. Of the 2,187 responses, $78.9 \%$ of survey participants $(1,726)$ were aware that the customer agreement contained a PDAA; 16\% (351) were not aware; 5\% (110) did not know. When broken down by type of survey participant, the percentages shift in a statistically significant manner. Thus, $63.29 \%$ of survey participants who answered this question and identified themselves as customers were aware that the customer agreement contained a PDAA before the dispute arose; $36.71 \%$ of customers were not aware. ${ }^{48}$

\footnotetext{
${ }^{48}$ To ensure enough observations for a response choice in order to run a valid chi-square test, for this analysis and all subsequent statistical analyses, we did not include the "do not know" response as a category if the response rate for that choice was less than $5 \%$ or less than 150 responses. Thus, because fewer than $5 \%$ of customers answered "do not know" to question 6(b), we eliminated that response from the "customer only" analysis.
} 
Question 7 asked the survey participants to provide the primary reason the dispute was filed in an arbitration forum. As shown below, of the 2,790 responses, the largest number of survey participants answered that the dispute was filed in an arbitration forum because it was required. ${ }^{49}$ The final column reports the distribution of answers just for those survey participants who identified themselves in response to question one as customers. This distribution is different in a statistically significant manner from the distribution for all survey participants.

\begin{tabular}{|c|c|c|c|}
\hline $\begin{array}{l}\text { Q7: Primary reason for filing the } \\
\text { dispute in arbitration }\end{array}$ & $\begin{array}{l}\text { Number of } \\
\text { survey } \\
\text { participants } \\
\text { who selected } \\
\text { this response }\end{array}$ & $\begin{array}{l}\text { Percentage of } \\
\text { survey } \\
\text { participants } \\
\text { who answered } \\
\text { this question }\end{array}$ & $\begin{array}{l}\text { Percentage of } \\
\text { customer survey } \\
\text { participants who } \\
\text { answered this } \\
\text { question }\end{array}$ \\
\hline Believed arbitration was required & 1,169 & 41.9 & 41.6 \\
\hline Did not initiate the claim & 709 & 25.4 & 3.84 \\
\hline A lawyer recommended it & 362 & 13.0 & 27.23 \\
\hline $\begin{array}{l}\text { Believed arbitration would be less } \\
\text { expensive than court }\end{array}$ & 204 & 7.3 & 13.45 \\
\hline $\begin{array}{l}\text { Believed arbitration would be faster } \\
\text { than court }\end{array}$ & 108 & 3.9 & 6.93 \\
\hline Do not know/do not recall & 110 & 3.9 & $\mathrm{~N} / \mathrm{A}$ \\
\hline $\begin{array}{l}\text { Believed arbitration would be more fair } \\
\text { than court }\end{array}$ & 75 & 2.7 & 3.59 \\
\hline Preferred arbitration for other reasons & 32 & 1.1 & 2.01 \\
\hline $\begin{array}{l}\text { Believed arbitration would provide a } \\
\text { larger recovery than court }\end{array}$ & 21 & 0.8 & 1.34 \\
\hline
\end{tabular}

\footnotetext{
${ }^{49}$ When recalculated to exclude those survey participants who indicated that they did not initiate the claim, those who filed in an arbitration forum because it was required totals $56.2 \%$.
} 


\section{Concerns about arbitration before filing}

When asked in question 8 about their concerns before the dispute was filed in arbitration, survey participants indicated as follows: ${ }^{50}$

\begin{tabular}{|c|c|c|c|}
\hline $\begin{array}{l}\text { Q8: Concerns } \\
\text { before arbitration } \\
\text { filed }\end{array}$ & $\begin{array}{l}\text { Number of survey } \\
\text { participants who } \\
\text { selected this } \\
\text { response }\end{array}$ & $\begin{array}{l}\text { Percentage of } \\
\text { survey participants } \\
\text { who answered this } \\
\text { question }\end{array}$ & $\begin{array}{l}\text { Percentage of } \\
\text { customer survey } \\
\text { participants who } \\
\text { answered this } \\
\text { question }\end{array}$ \\
\hline $\begin{array}{l}\text { I was concerned that } \\
\text { it would not be a fair } \\
\text { process }\end{array}$ & 1,178 & 39.0 & 39.07 \\
\hline I had no concerns & 965 & 31.9 & 28.04 \\
\hline $\begin{array}{l}\text { I was concerned that } \\
\text { the arbitrators would } \\
\text { be biased }\end{array}$ & 951 & 31.4 & 33.55 \\
\hline $\begin{array}{l}\text { I was concerned } \\
\text { about the } \\
\text { composition of the } \\
\text { arbitration panel }\end{array}$ & 847 & 28.0 & 25.02 \\
\hline $\begin{array}{l}\text { I was concerned that } \\
\text { it would be } \\
\text { expensive }\end{array}$ & 508 & 16.8 & 17.51 \\
\hline $\begin{array}{l}\text { I was concerned that } \\
\text { it would be a slow } \\
\text { process }\end{array}$ & 423 & 14.0 & 16.56 \\
\hline I had other concerns & 410 & 13.6 & 9.79 \\
\hline $\begin{array}{l}\text { I don't recall if I had } \\
\text { any concerns }\end{array}$ & 170 & 5.6 & 8.68 \\
\hline
\end{tabular}

\footnotetext{
${ }^{50}$ The question instructed survey participants to select all that applied. We asked about parties' pre-filing concerns because we believe it is useful to compare the parties' concerns before filing with the perception of the process after the case closed.

${ }^{51}$ The difference between the answers for all survey participants and customers only was not statistically significant for most of the choices.
} 


\section{Geographic distribution}

Question 9 asked survey participants to write the state in which the hearing was scheduled to take place in their most recent dispute. If the dispute was a Simplified Arbitration, the survey directed participants to write "paper case." We then coded the 2,523 responses by region, according to FINRA Dispute Resolution's four regions - Northeast, Southeast, Midwest and West. The responses demonstrate that the survey participants represent a fairly even crosssection of the four regions in the country: ${ }^{52}$

\begin{tabular}{|l|l|l|} 
Q9: Region & $\begin{array}{l}\text { Number of } \\
\text { survey participants whose } \\
\text { hearing was scheduled to } \\
\text { take place in this region }\end{array}$ & $\begin{array}{l}\text { Percentage of survey participants } \\
\text { who answered this question }\end{array}$ \\
\hline Northeast & 559 & 22.16 \\
\hline Southeast & 586 & 23.23 \\
\hline Midwest & 526 & 20.85 \\
\hline West & 644 & 25.53 \\
\hline Paper case & 208 & 8.24 \\
\hline
\end{tabular}

\section{E. Nature of most recent arbitration dispute}

Questions 10-12 asked survey participants to identify certain parameters about the dispute. Question 10 (2,947 responses) asked about the amount of damages claimed (excluding punitive damages, attorneys' fees, interest and costs) in the most recent dispute:

\section{Q10: Amount of damages claimed in most recent dispute}

Not exceeding $\$ 25,000$

$\$ 25,001-\$ 50,000$
$\$ 50,001-\$ 100,000$
$\$ 100,001-\$ 250,000$
$\$ 250,001-\$ 1,000,000$
More than $\$ 1,000,000$

Don't know

\section{Number of survey participants who selected this response}

\section{8}

\section{0}

351

642

861

425

100
Percentage of survey participants who answered this question

12.1

\section{1}

11.9

21.8

29.2

\section{4}

3.4

\footnotetext{
52 In 2006, NASD Dispute Resolution closed its Mid-Atlantic region, and realigned the regional office assignments for several of its 68 hearing locations. Since not all hearing locations were reassigned to the same region, it is not possible to compare the regional distributions of survey participants' hearing location with the regional distribution of the NASD and NYSE dockets during the same time period.
} 
Question 11 (2,885 responses) asked how the dispute was resolved:

\begin{tabular}{|c|c|c|c|}
\hline $\begin{array}{l}\text { Q11: How the } \\
\text { most recent } \\
\text { dispute was } \\
\text { resolved }\end{array}$ & $\begin{array}{l}\text { Number of survey } \\
\text { participants who } \\
\text { selected this } \\
\text { response }\end{array}$ & $\begin{array}{l}\text { Percentage of } \\
\text { survey participants } \\
\text { who answered this } \\
\text { question }\end{array}$ & $\begin{array}{l}\text { Percentage of customer } \\
\text { survey participants who } \\
\text { answered this question } \\
(\mathrm{N}=1237)\end{array}$ \\
\hline $\begin{array}{l}\text { Award to } \\
\text { customer after } \\
\text { hearing }\end{array}$ & 676 & 23.4 & 24.41 \\
\hline $\begin{array}{l}\text { Award to } \\
\text { customer based } \\
\text { on papers }\end{array}$ & 129 & 4.5 & 8.25 \\
\hline $\begin{array}{l}\text { Claimant } \\
\text { withdrew the } \\
\text { claim }\end{array}$ & 63 & 2.2 & 1.86 \\
\hline $\begin{array}{l}\text { Parties settled on } \\
\text { their own }\end{array}$ & 682 & 23.6 & 22.47 \\
\hline $\begin{array}{l}\text { Parties settled } \\
\text { with aid of } \\
\text { mediator }\end{array}$ & 456 & 15.8 & 16.41 \\
\hline $\begin{array}{l}\text { No award to } \\
\text { customer based } \\
\text { on papers }\end{array}$ & 95 & 3.3 & 6.22 \\
\hline $\begin{array}{l}\text { Dismissed before } \\
\text { hearing }\end{array}$ & 62 & 2.1 & 1.94 \\
\hline $\begin{array}{l}\text { No award to } \\
\text { customer after } \\
\text { hearing }\end{array}$ & 630 & 21.8 & 18.43 \\
\hline Do not know & 92 & 3.2 & $\mathrm{~N} / \mathrm{A}$ \\
\hline
\end{tabular}

Only survey participants involved in a dispute that resulted in an award for the customer answered question 12. Question 12a (789 responses) asked the amount of the total award (excluding punitive damages, attorneys' fees, interest and costs):

\begin{tabular}{|c|c|c|}
$\begin{array}{c}\text { Q12a: Amount of damages } \\
\text { awarded in most recent } \\
\text { dispute }\end{array}$ & $\begin{array}{c}\text { Number of survey } \\
\text { participants who selected } \\
\text { this response }\end{array}$ & $\begin{array}{c}\text { Percentage of survey } \\
\text { participants who answered } \\
\text { this question }\end{array}$ \\
\hline$\$ 1.00-\$ 10,000$ & 108 & 13.7 \\
$\$ 10,001-\$ 50,000$ & 239 & 30.3 \\
\hline$\$ 50,001-\$ 250,000$ & 290 & 36.8 \\
\hline$\$ 250,001-\$ 1,000,000$ & 102 & 12.9 \\
\hline More than $\$ 1,000,000$ & 38 & 4.8 \\
\hline Don't know & 12 & 1.5 \\
\hline
\end{tabular}


Question 12b (786 responses) asked what percentage of damages originally claimed (excluding punitive damages, attorneys' fees, interest and costs) the award represents:

\begin{tabular}{|c|c|c|}
\hline $\begin{array}{c}\text { Q12b: For awards, } \\
\text { percentage of damages } \\
\text { originally claimed } \\
\text { Less than 1\% }\end{array}$ & $\begin{array}{c}\text { Number of survey } \\
\text { participants who selected } \\
\text { this response }\end{array}$ & $\begin{array}{c}\text { Percentage of survey } \\
\text { participants who answered } \\
\text { this question }\end{array}$ \\
\hline $1-10 \%$ & 42 & 5.3 \\
\hline $11-25 \%$ & 134 & 17.0 \\
\hline $26-49 \%$ & 148 & 18.8 \\
\hline $50-74 \%$ & 158 & 20.1 \\
$75-99 \%$ & 99 & 12.6 \\
\hline $100 \%$ & 57 & 7.3 \\
\hline Don't know & 66 & 8.4 \\
\hline
\end{tabular}

These responses demonstrate that the survey participants represent a cross-section of arbitration participants based on the amount of the claim, the amount of damages awarded (if any), and the manner in which the case was resolved. ${ }^{53}$ No one type of arbitration participant dominated the survey participants.

\section{F. Composition of arbitration panel}

Questions 13-15 focused on the composition of the arbitration panel and any perceived differences between public and industry arbitrators. Question 13 (2,898 responses) asked all survey participants how many arbitrators were appointed to decide the dispute. $66.2 \%$ of survey participants $(1,919)$ reported that three arbitrators were appointed to decide the dispute; $16.1 \%$ (466) reported that one arbitrator was appointed. In addition, 6.8\% (197) answered that no arbitrators were appointed; another 10.9\% (316) did not know.

The survey directed those who responded that three arbitrators were appointed to answer questions 14a-14e.

Q14a (1,896 responses): $77.8 \%(1,475)$ knew, prior to the filing of the arbitration, that one arbitrator would be an "industry arbitrator." In contrast, 18.9\% (359) reported that they did not know this fact, and another 3.3\% (62) did not recall. When broken out by type of survey participant, $47 \%$ of customer-survey participants knew this fact, compared to $94 \%$ of all other types of survey participants.

\footnotetext{
${ }^{53}$ Although it would be instructive to compare the distribution of survey participants by how the dispute was resolved to FINRA's statistics on how its cases closed, comparisons are not possible because the categories FINRA tracks are different from those tracked in this survey.
} 
* Q14b (1,895 responses): 71.6\% of survey participants $(1,356) \mathrm{knew}$, at some time during the dispute, which arbitrators were "public" and which arbitrator was "industry." $22.1 \%$ (418) did not know; 6.4\% (121) did not recall. When broken out by type of survey participant, $48 \%$ of customer-survey participants knew this information compared to $88 \%$ of all other types of survey participants.

Q Q14c (1,885 responses): $35.7 \%$ (673) said there was no difference between the performance of the public arbitrators and the industry arbitrator; $32.8 \%$ (618) had no opportunity to assess the arbitrators' performance; $24.4 \%$ (459) answered that there was a difference; and $7.2 \%$ (135) did not know or recall. When broken out by type of survey participant, the distribution of responses is a bit different: $21.5 \%$ of customers did not perceive a difference; $42.8 \%$ of customers had no opportunity to assess; and $24 \%$ of customers perceived a difference in performance between the industry and public arbitrator.

Q14d (1,888 responses): $39.1 \%$ (739) disagreed with the statement that the industry arbitrator favored one side over the other at any time during the dispute; $19.9 \%$ (375) said the industry arbitrator favored at least one securities party; 5.5\% (104) answered that the industry arbitrator favored the customer; $28.9 \%$ (545) had no opportunity to assess; and $6.6 \%$ (125) did not know or recall. In contrast, for customer-survey participants only: $22 \%$ of customers disagreed that the industry arbitrator favored one side or the other at any time during the dispute; $36.5 \%$ perceived that the industry arbitrator favored at least one securities party; $1.8 \%$ perceived that the industry arbitrator favored the customer; and $39.8 \%$ of customers had no opportunity to assess the performance of the industry arbitrator.

Q14e (1,571 responses): ${ }^{54} 53.7 \%$ (844 responses) answered that the award was unanimous; $5.7 \%$ (90 responses) said it was not; and 40.5\% (637 responses) did not know. For customer survey participants only, 29.3\% stated that the award was unanimous, $9.6 \%$ answered that it was not, and $61.2 \%$ did not know.

Notably, the differences in customer-only vs. all survey participant types for responses to questions $14 \mathrm{a}-14 \mathrm{e}$ were statistically significant.

Question 15 (2,271 responses) asked whether any public arbitrator favored one side over the other at any time during the dispute. $39.3 \%$ (892) said no while $15.8 \%$ (359) said the public arbitrator favored at least one securities party, 8.9\% (201) said that the public arbitrator favored the customer, $27.9 \%$ (634) said there was no opportunity to assess; and 8.1\% (185) did not know or recall. For customers, the answers to question 15 reveal different perceptions: $24.2 \%$ of customers responded that the public arbitrator did not favor one side over the other at any time

\footnotetext{
${ }^{54}$ The sub-question's assumption that there was an award likely explains the lower response to this question than the other sub-questions in 14.
} 
during the dispute; $28.7 \%$ said the public arbitrator favored at least one securities party; $2.2 \%$ of customers said that the public arbitrator favored the customer; $33.37 \%$ said there was no opportunity to assess; and $11.58 \%$ did not know or recall.

\section{G. Statements seeking range of responses (Likert scale questions)}

Questions 16-34 reflect "Likert scale" questions, which are statements asking for a range of responses and are commonly used in survey research. These questions directed survey participants to read a statement and then indicate their response to that question as "strongly agree, agree, neither agree nor disagree, disagree, or strongly disagree." Each statement also supplied a "not applicable" as well as a "don't know" option. For each question, we have produced two charts. The first chart provides the statement and the range of responses distributed by percentage of all valid survey participants (excluding "not applicable" responses). The second chart provides the same information with respect to two categories of survey participants, those who identified themselves as customers and those who identified themselves as non-customers, in order to determine whether customers' responses were different from the responses of the other survey participants as a group. ${ }^{55}$ In general, customers had more negative perceptions of the arbitration process. In addition, in some questions, the customers expressed a greater lack of knowledge about the process than other survey participants. For all questions, the differences were statistically significant.

\footnotetext{
${ }^{55}$ Because not everyone who answered these questions had previously identified the nature of their involvement in the process, the total number of responses for the second set of charts is less than the total number of responses for the first set. In addition, for some questions the first chart includes “don't know" responses, while the second chart does not. In a few instances, where the discrepancy between the two amounts is large, it results in anomalous comparisons between the two charts.
} 

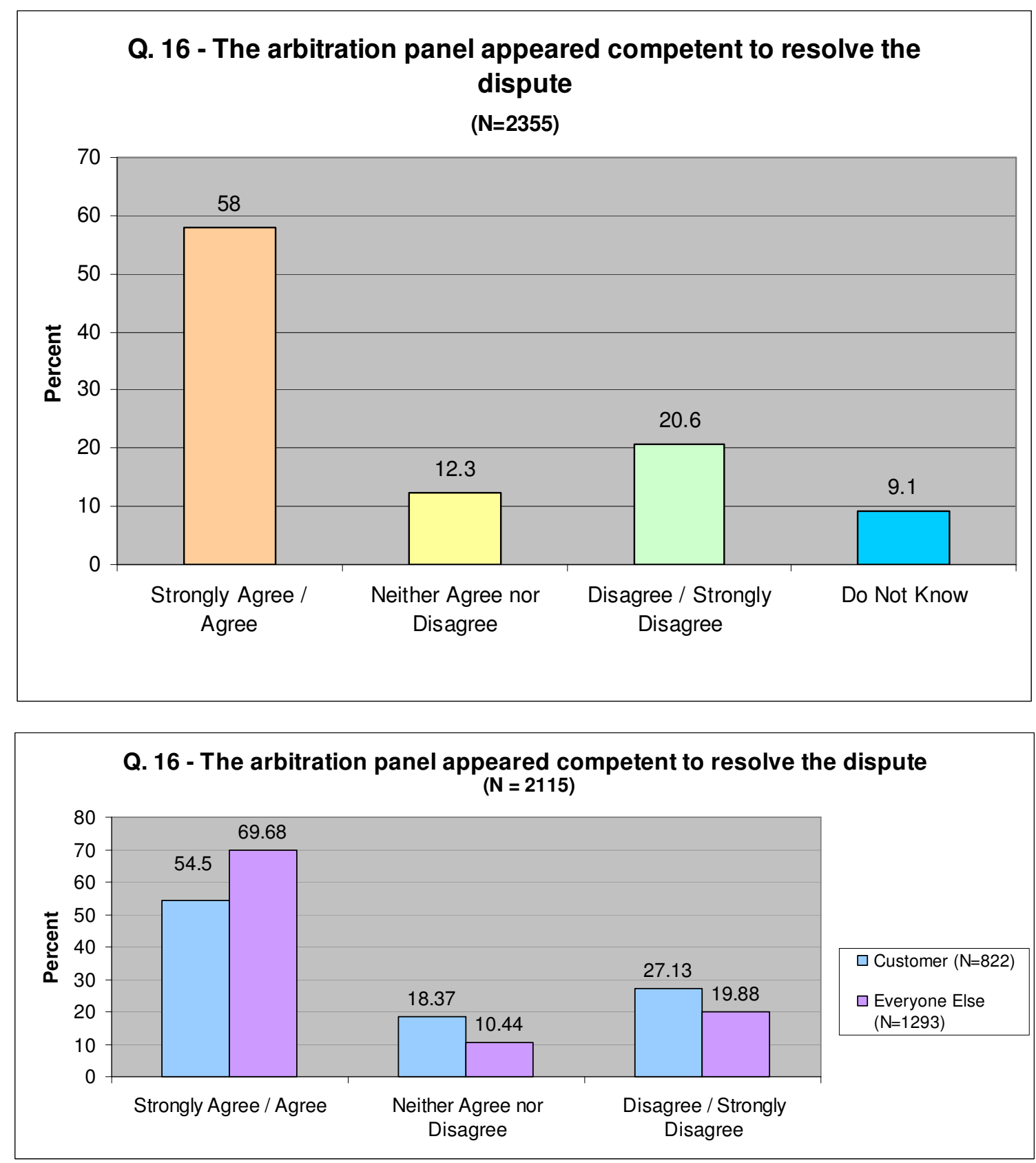

While $58 \%$ of all survey participants agreed with the statement that "the arbitration panel appeared competent to resolve the dispute," $54.5 \%$ of customers agreed with it. $20.6 \%$ of all survey participants disagreed with the statement, compared with $27.13 \%$ of customers. 

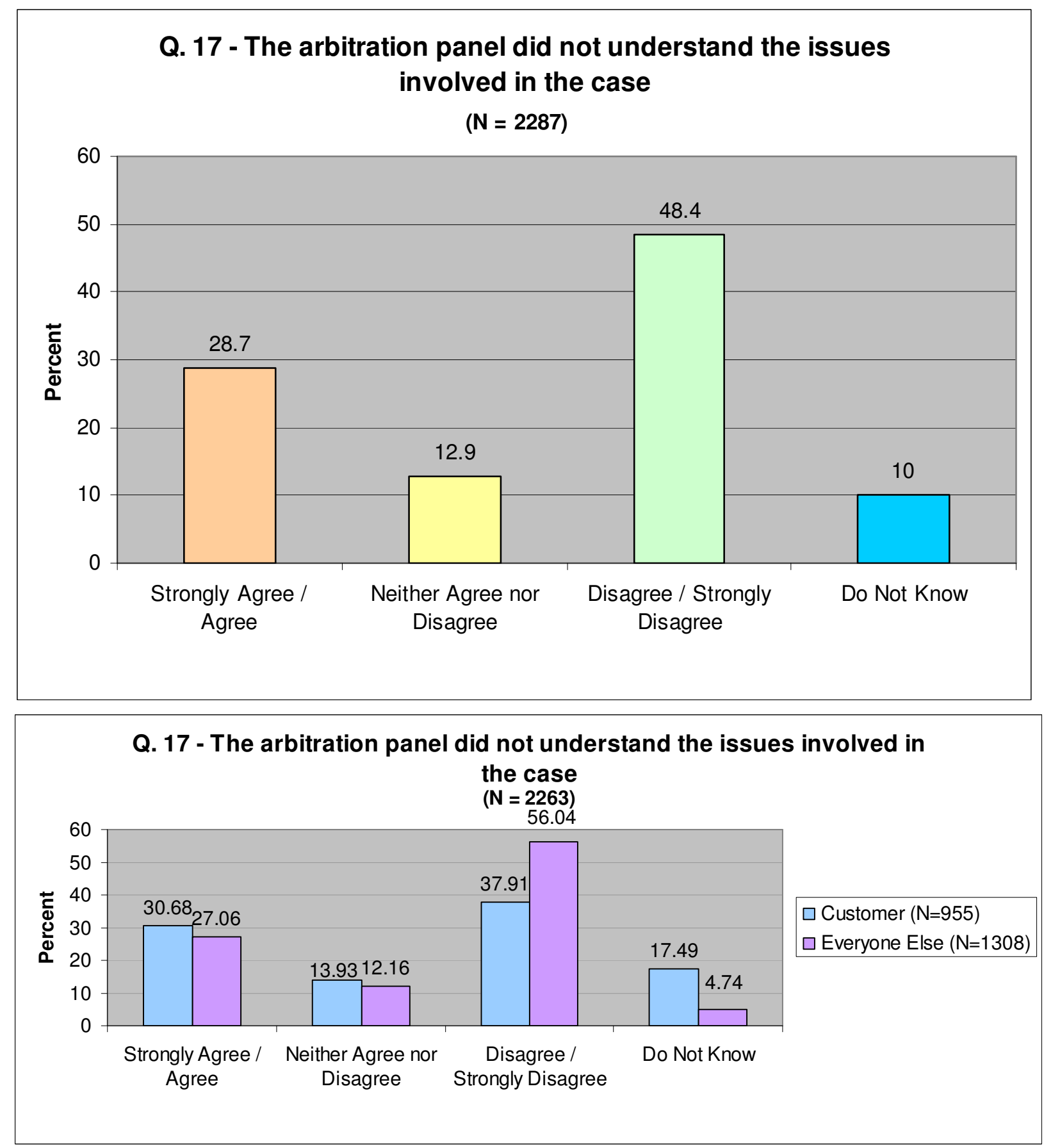

While $48.4 \%$ of all survey participants disagreed with the statement that "the arbitration panel did not understand the issues involved in the case," $37.91 \%$ of customers disagreed with it. $28.7 \%$ of all survey participants agreed with the statement, compared with $30.68 \%$ of customers. $10 \%$ of all survey participants "did not know," compared with $17.49 \%$ of all customers. 

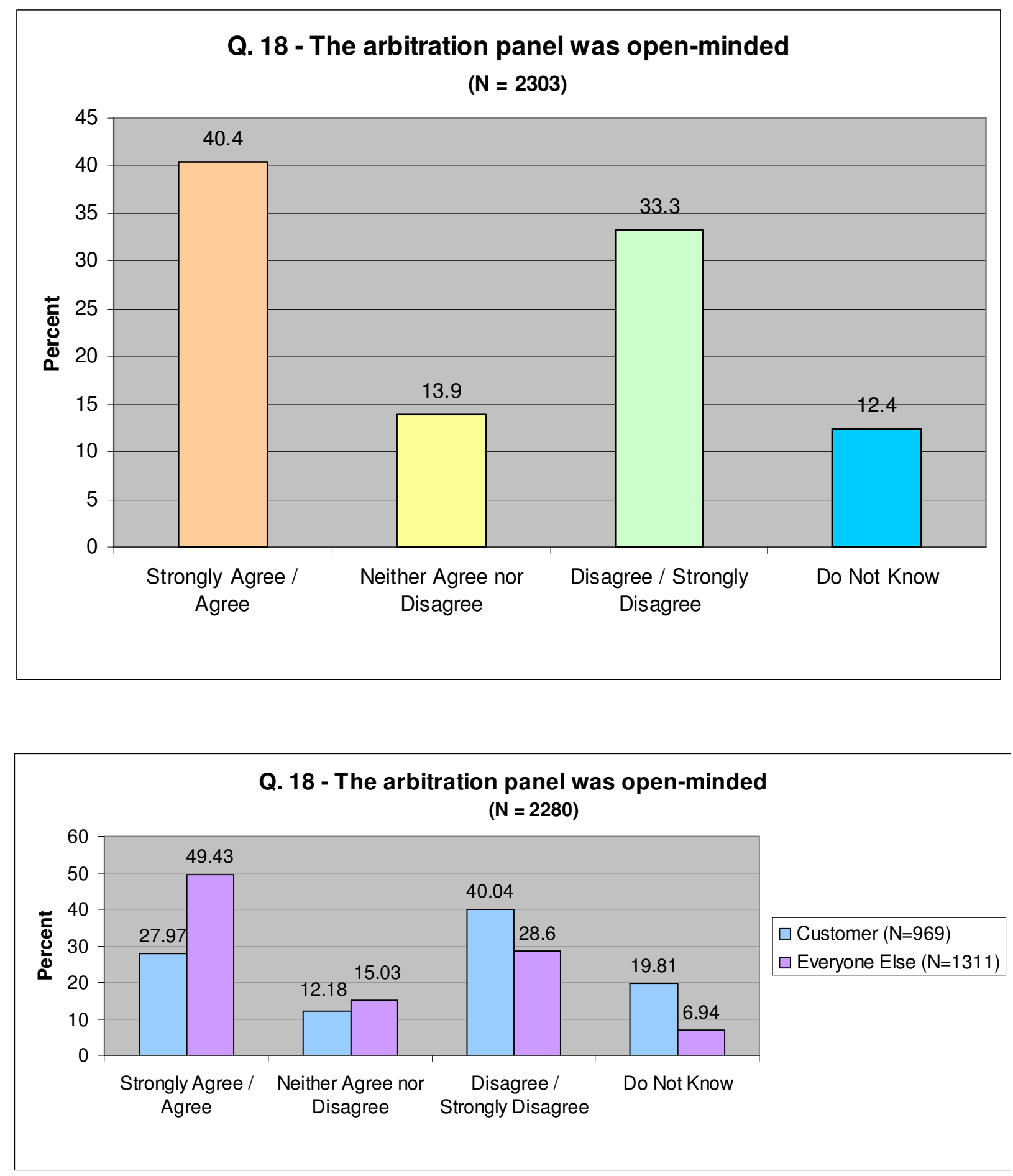

While $40.4 \%$ of all survey participants agreed with the statement that "the arbitration panel was open-minded," $27.97 \%$ of customers agreed with it. $33.3 \%$ of all survey participants disagreed with the statement, compared with $40.04 \%$ of customers. Another $12.4 \%$ of all survey participants did not know, compared with $19.81 \%$ of customers. 

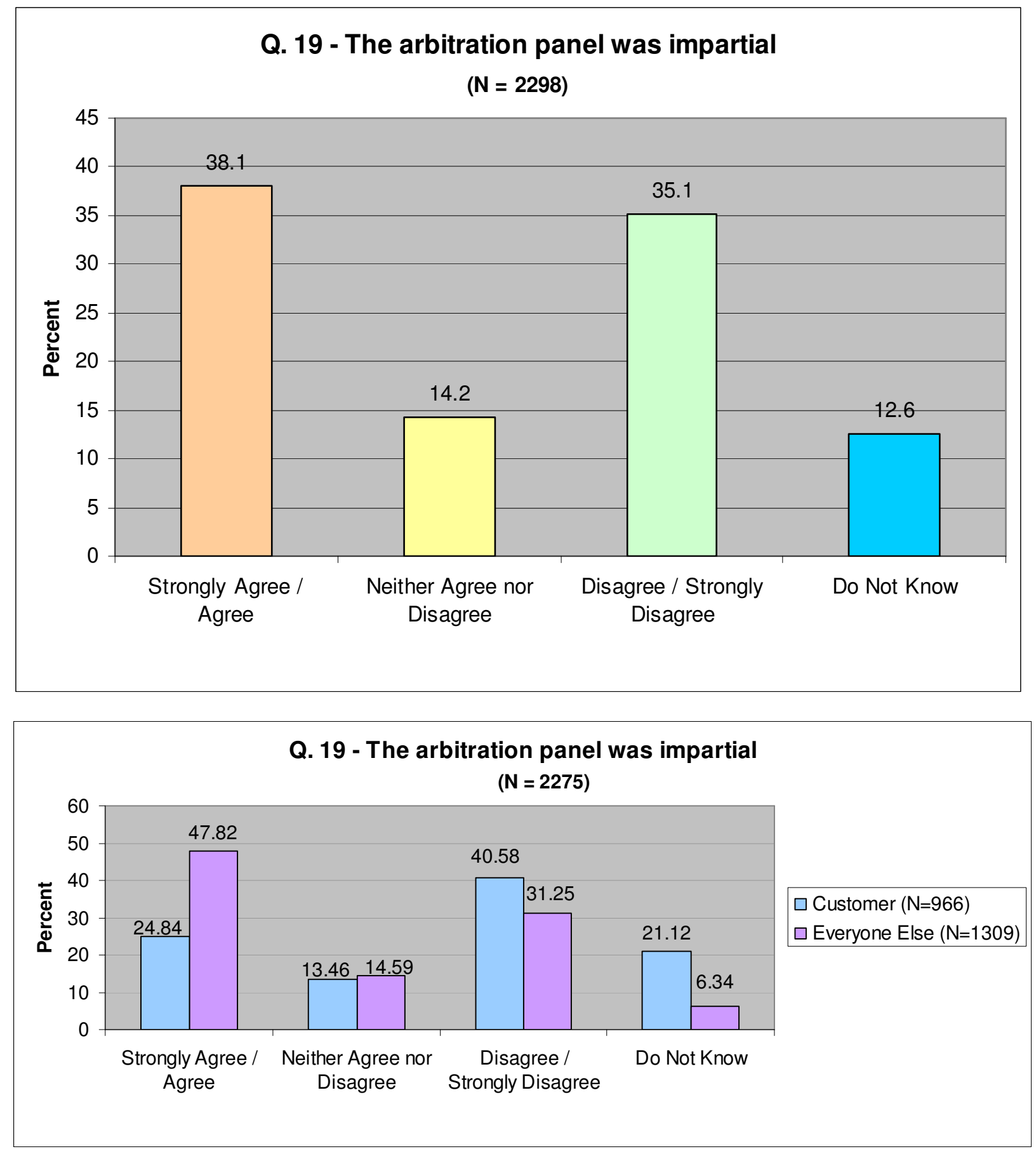

While $38.1 \%$ of all survey participants agreed with the statement that "the arbitration panel was impartial," $24.84 \%$ of customers agreed with it. $35.1 \%$ of all survey participants disagreed with the statement, compared to $40.58 \%$ of customers. Another $12.6 \%$ of all survey participants did not know, compared with $21.12 \%$ of customers. ${ }^{56}$

\footnotetext{
${ }^{56}$ A small number of survey participants answered this question while indicating in response to question 11 that their most recent dispute did not progress to a hearing. Thus, a small number of responses to this question appear to
} 

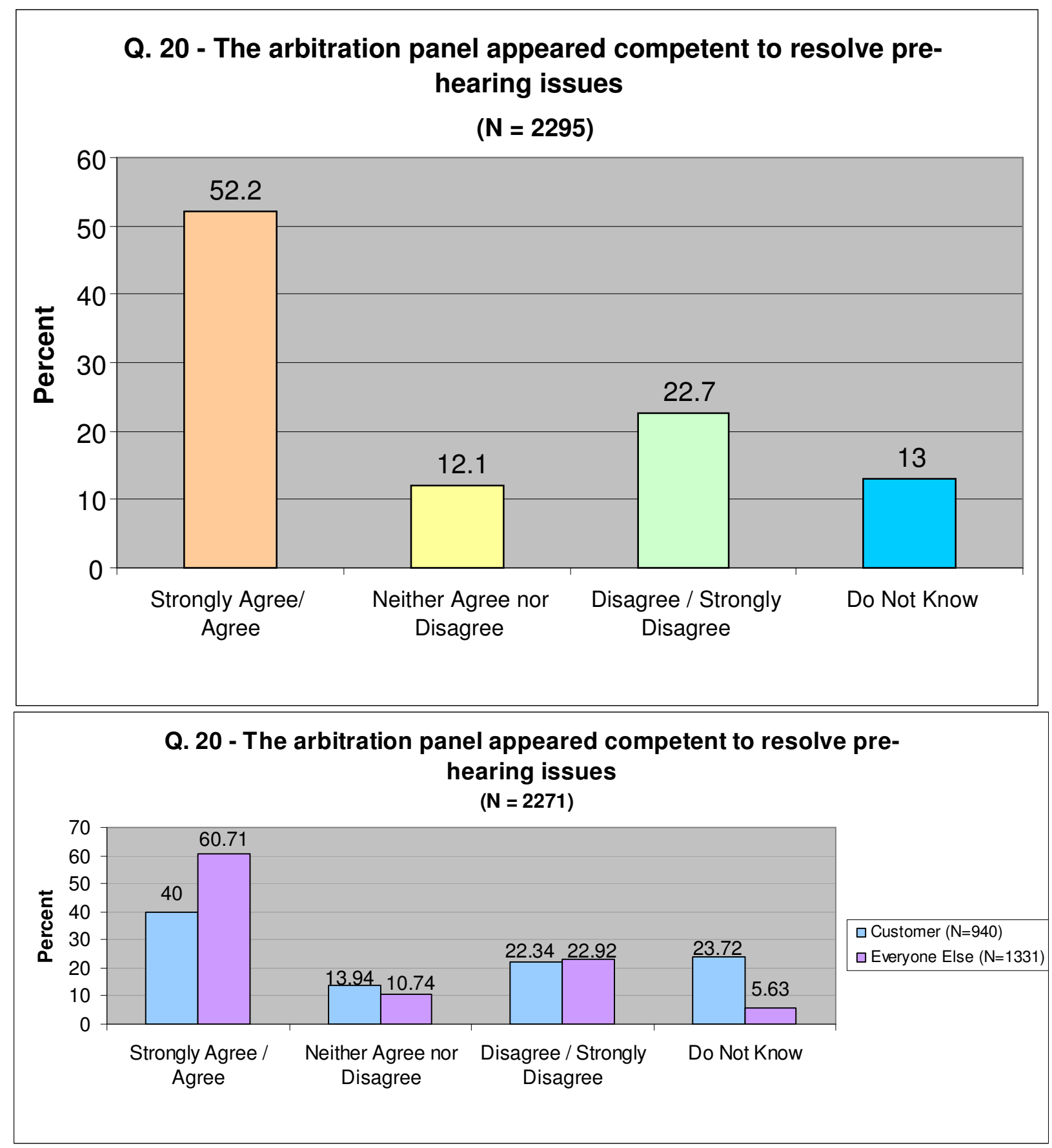

While $52.2 \%$ of survey participants agreed with the statement that "the arbitration panel appeared competent to resolve pre-hearing issues," $40 \%$ of customers agreed with it. $22.7 \%$ of survey participants disagreed with the statement, roughly comparable to the $22.34 \%$ of all customers. Another $13 \%$ of all survey participants did not know, compared with $23.72 \%$ of customers.

be based on perceptions derived from something other than those participants' experiences at a hearing in their most recent dispute that was filed for arbitration. This observation also applies to the data for questions 22 through 26 . 

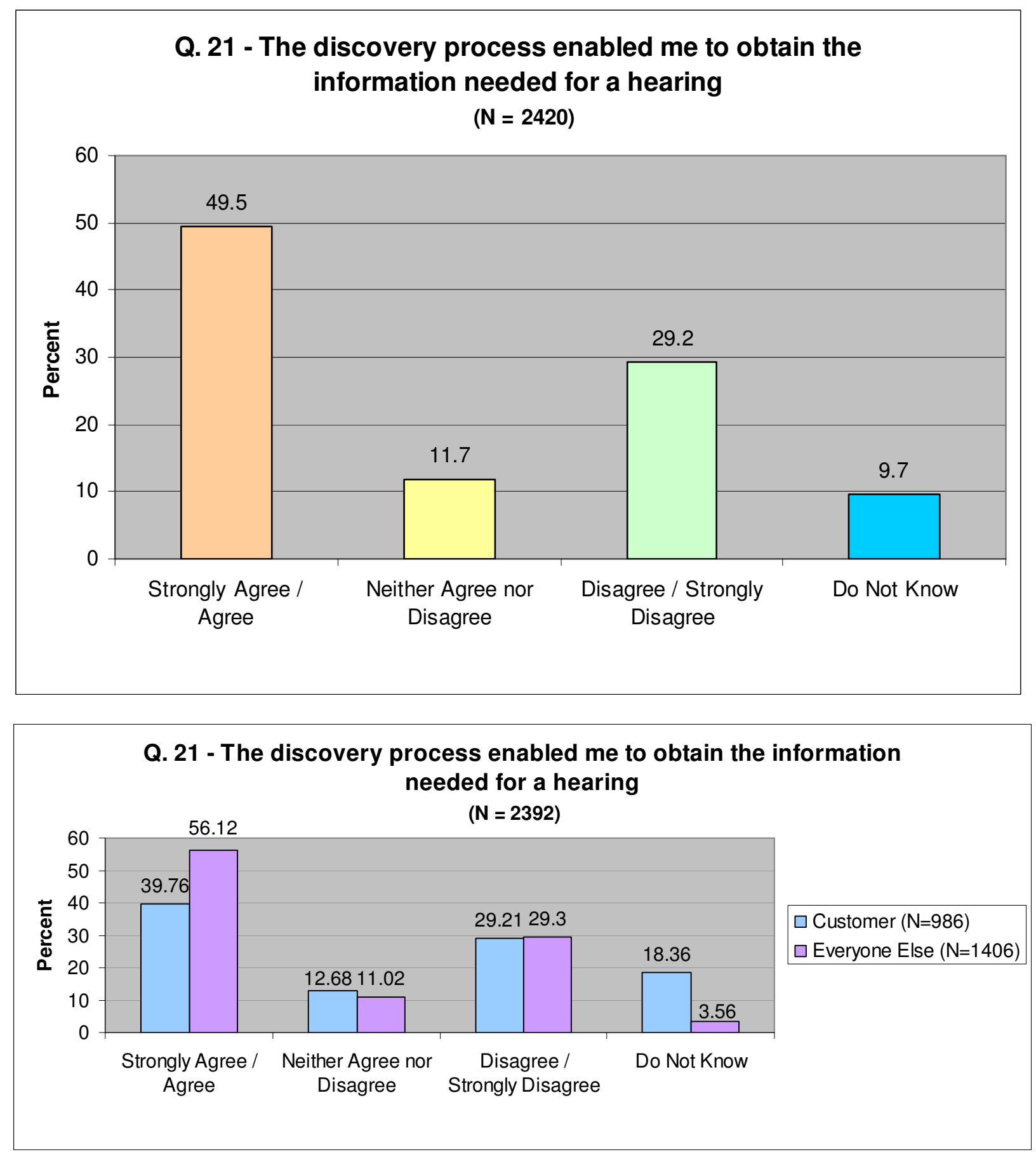

While $49.5 \%$ of all survey participants agreed with the statement that "the discovery process enabled me to obtain the information necessary for a hearing," $39.76 \%$ of customers agreed with it. The percentages of those who disagreed with the statement are virtually identical $-29.2 \%$ of all survey participants and $29.21 \%$ of customers. Another $9.7 \%$ of all survey participants did not know, compared with $18.36 \%$ of customers. 

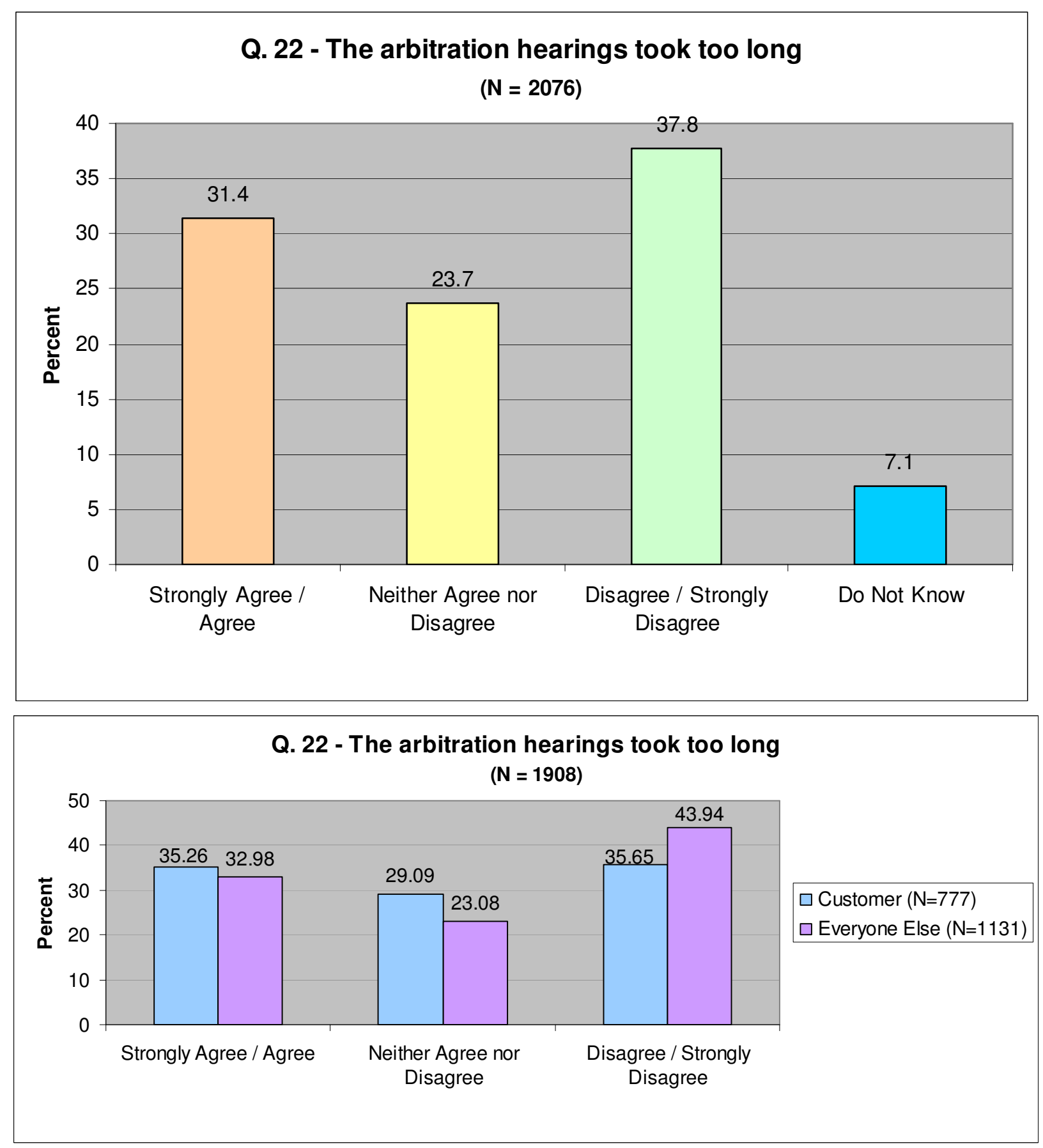

While $37.8 \%$ of all survey participants disagreed with the statement that "the arbitration hearings took too long," $35.65 \%$ of customers disagreed with it. $31.4 \%$ of all survey participants agreed with the statement, compared to $35.26 \%$ of customers. 

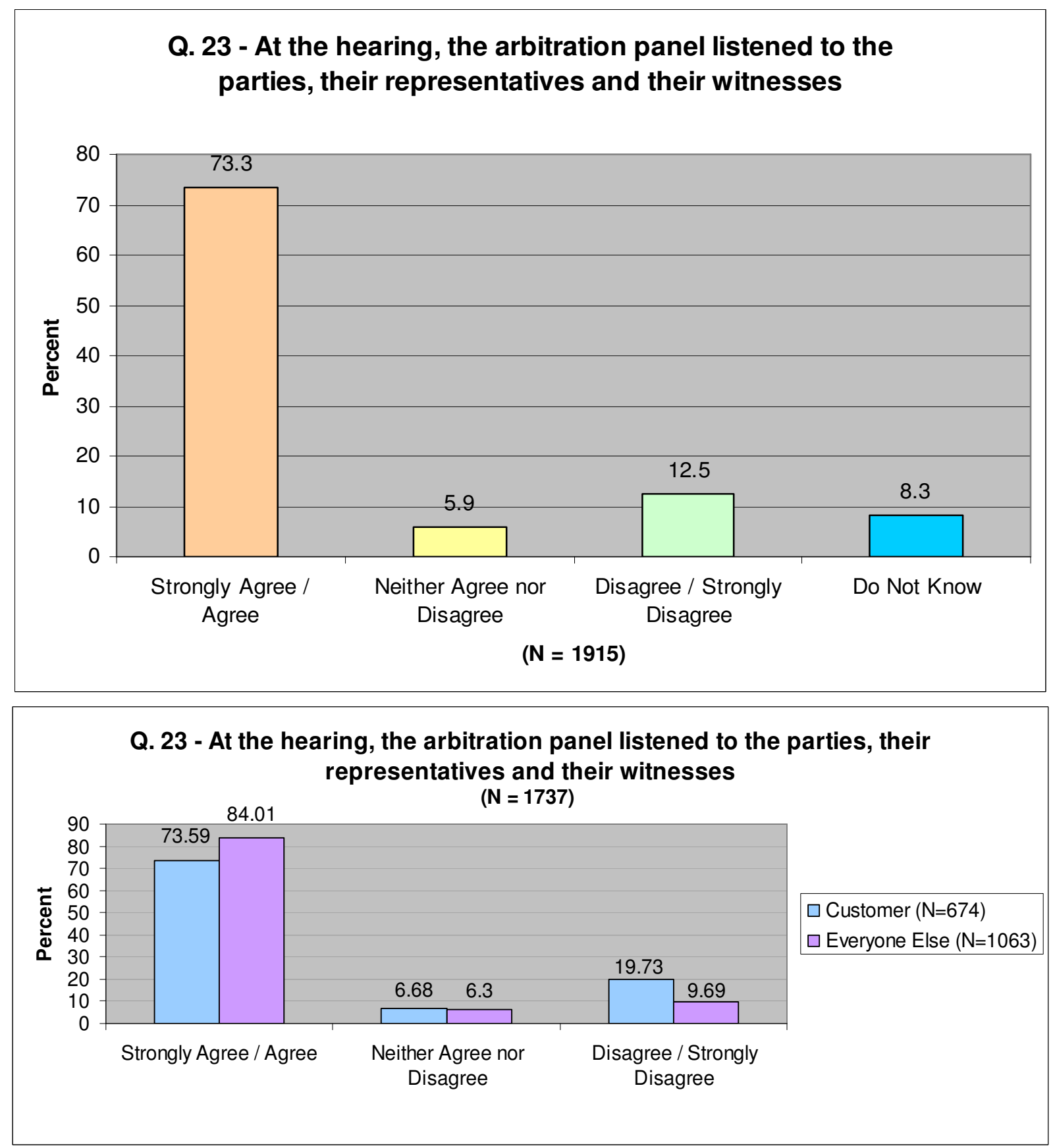

$73.3 \%$ of survey participants agreed with the statement that "at the hearing, the arbitration panel listened to the parties, their representatives and their witnesses," roughly comparable to the $73.59 \%$ of customers, but less than the $84.01 \%$ of non-customers. While $12.5 \%$ of survey participants disagreed with the statement, $19.73 \%$ of customers disagreed with it. $^{57}$

\footnotetext{
${ }^{57}$ The number of customer survey participants who answered this question is far lower than the total number of survey participants who answered this question, thus making the comparisons between the two less meaningful.
} 

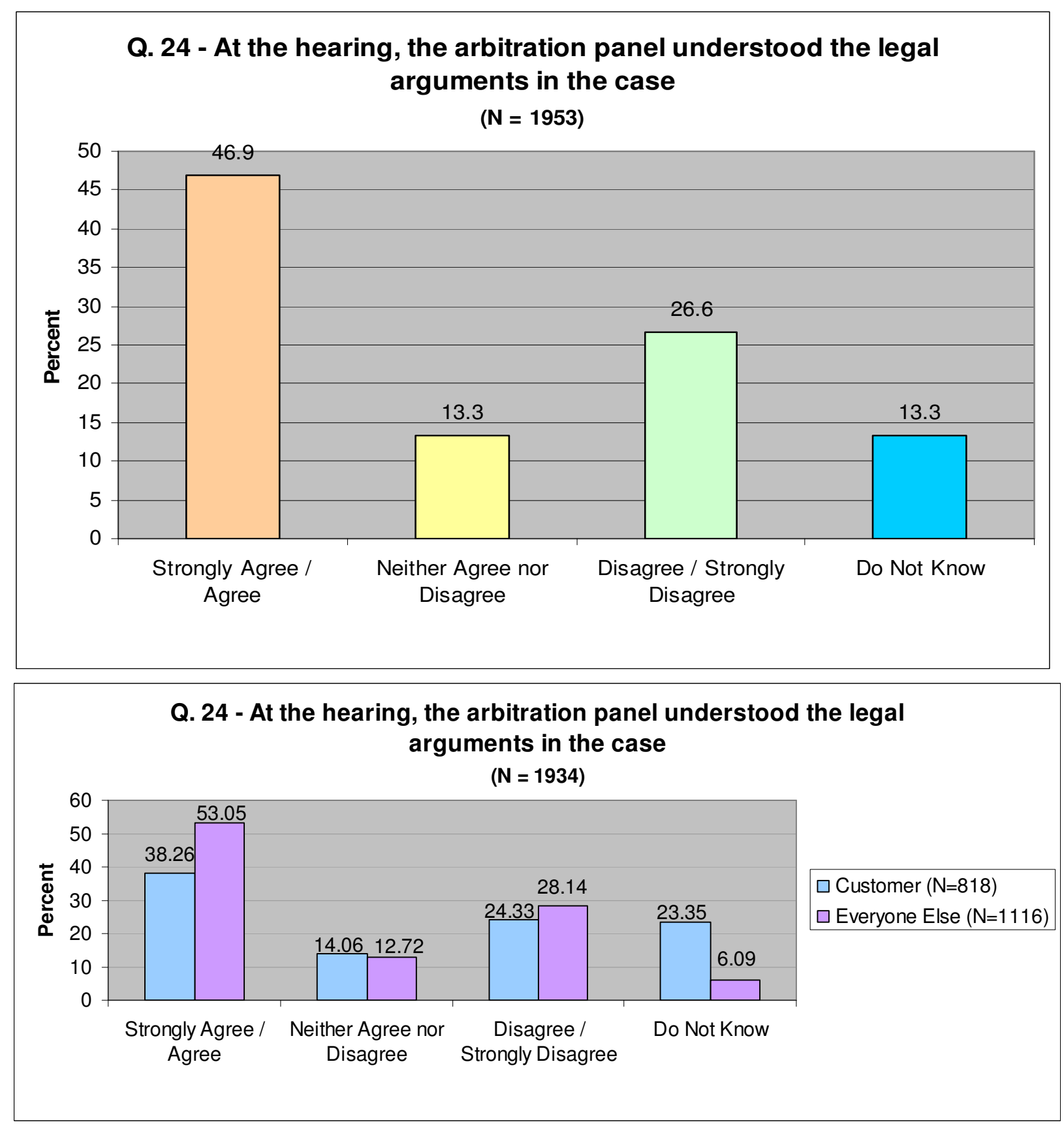

While $46.9 \%$ of all survey participants agreed with the statement that "at the hearing, the arbitration panel understood the legal arguments in the case," $38.26 \%$ of customers agreed with it. $26.6 \%$ of all survey participants disagreed with the statement, compared with $24.33 \%$ of customers. $13.3 \%$ of all survey participants said they did not know, compared with $23.35 \%$ of customers. 

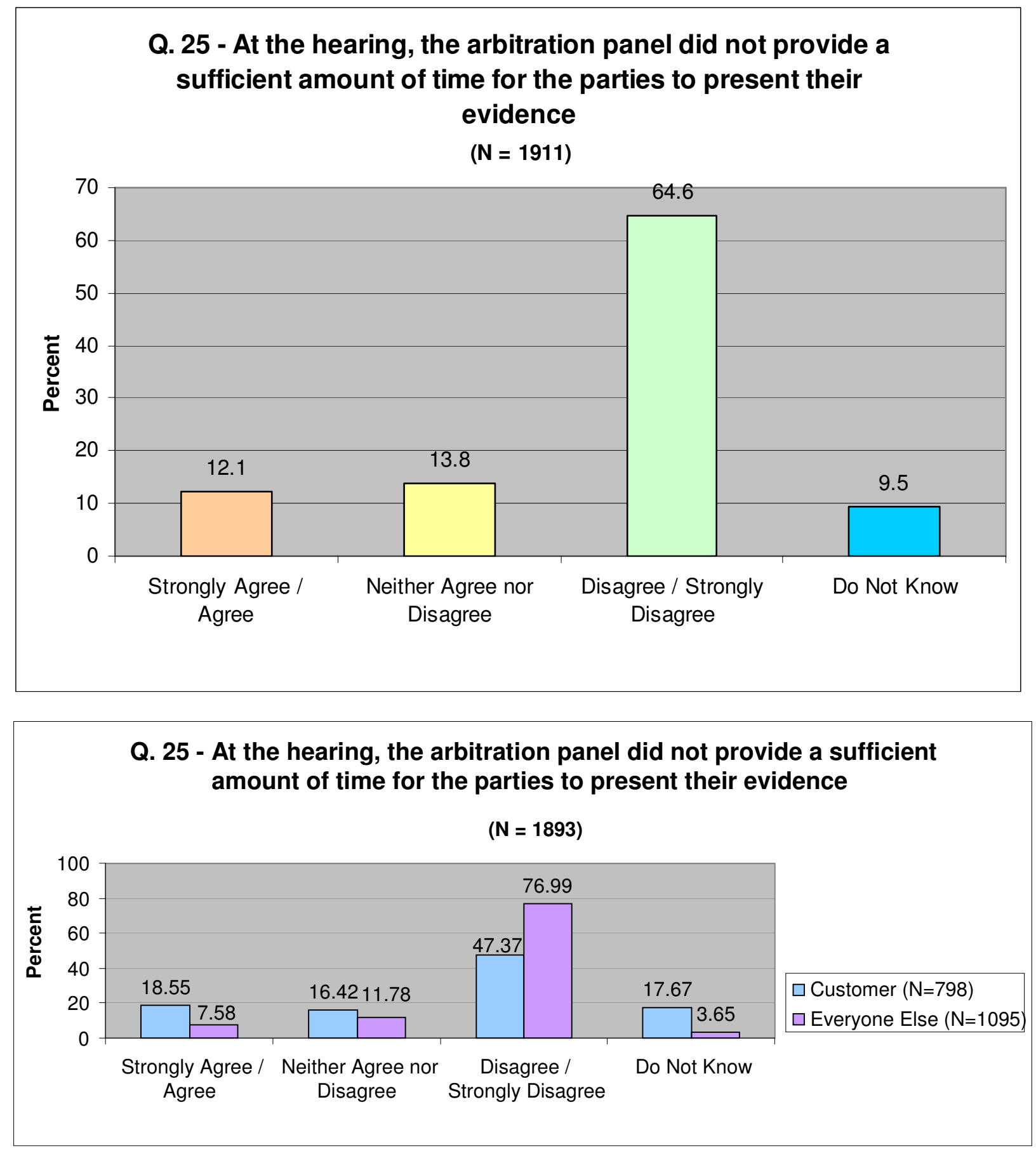

While $64.6 \%$ of all survey participants disagreed with the statement that "at the hearing, the arbitration panel did not provide a sufficient amount of time for the parties to present their evidence," $47.37 \%$ of customers agreed with it. $12.1 \%$ of all survey participants agreed with the statement, compared with $18.55 \%$ of customers. Another $9.5 \%$ of all survey participants said they did not know, compared with $17.67 \%$ of customers. 

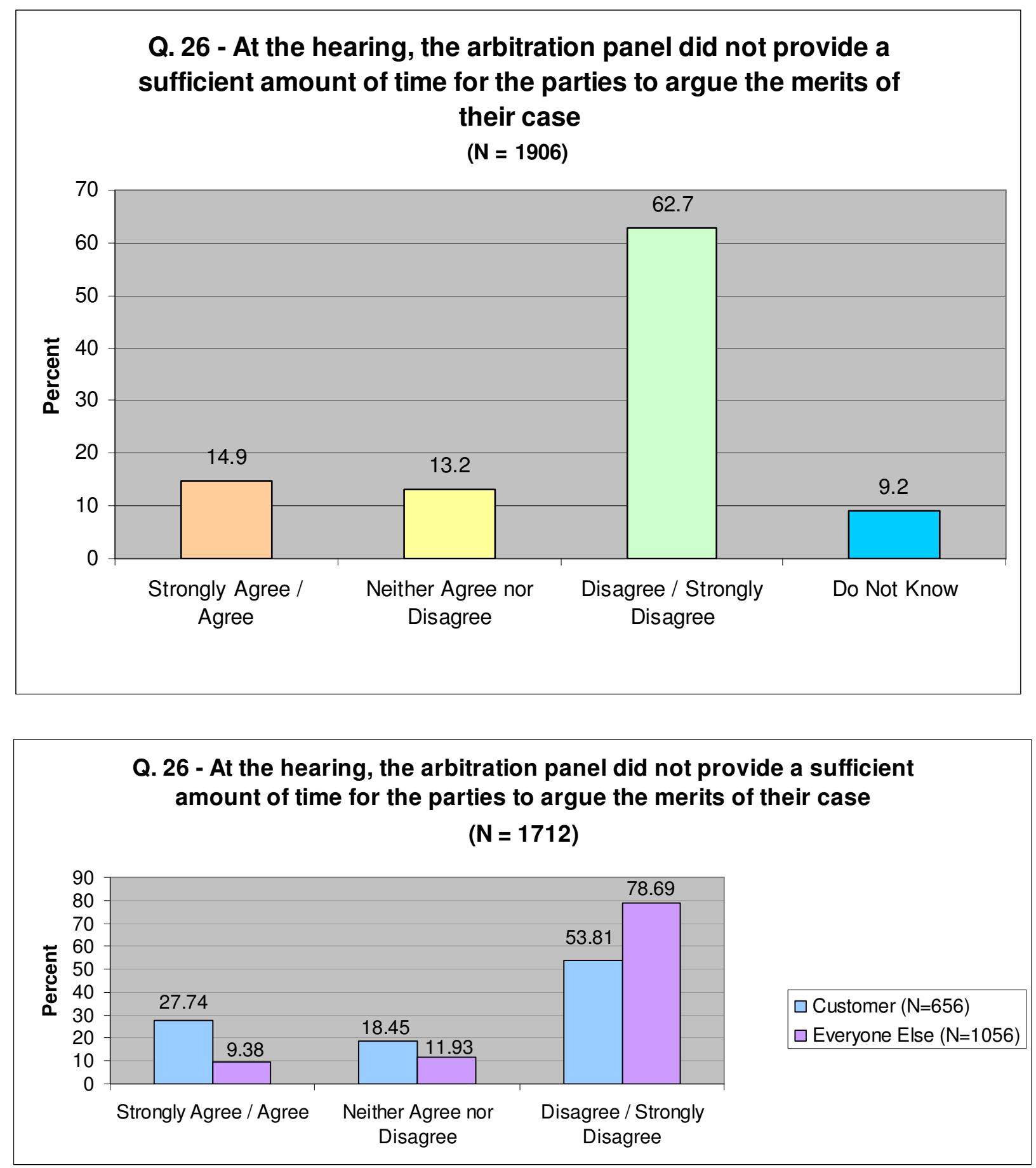

While $62.7 \%$ of all survey participants disagreed with the statement that "at the hearing, the arbitration panel did not provide a sufficient amount of time for the parties to argue the merits of their case," $53.81 \%$ of customers disagreed with it. $14.9 \%$ of all survey participants agreed with the statement, compared with $27.74 \%$ of customers. 

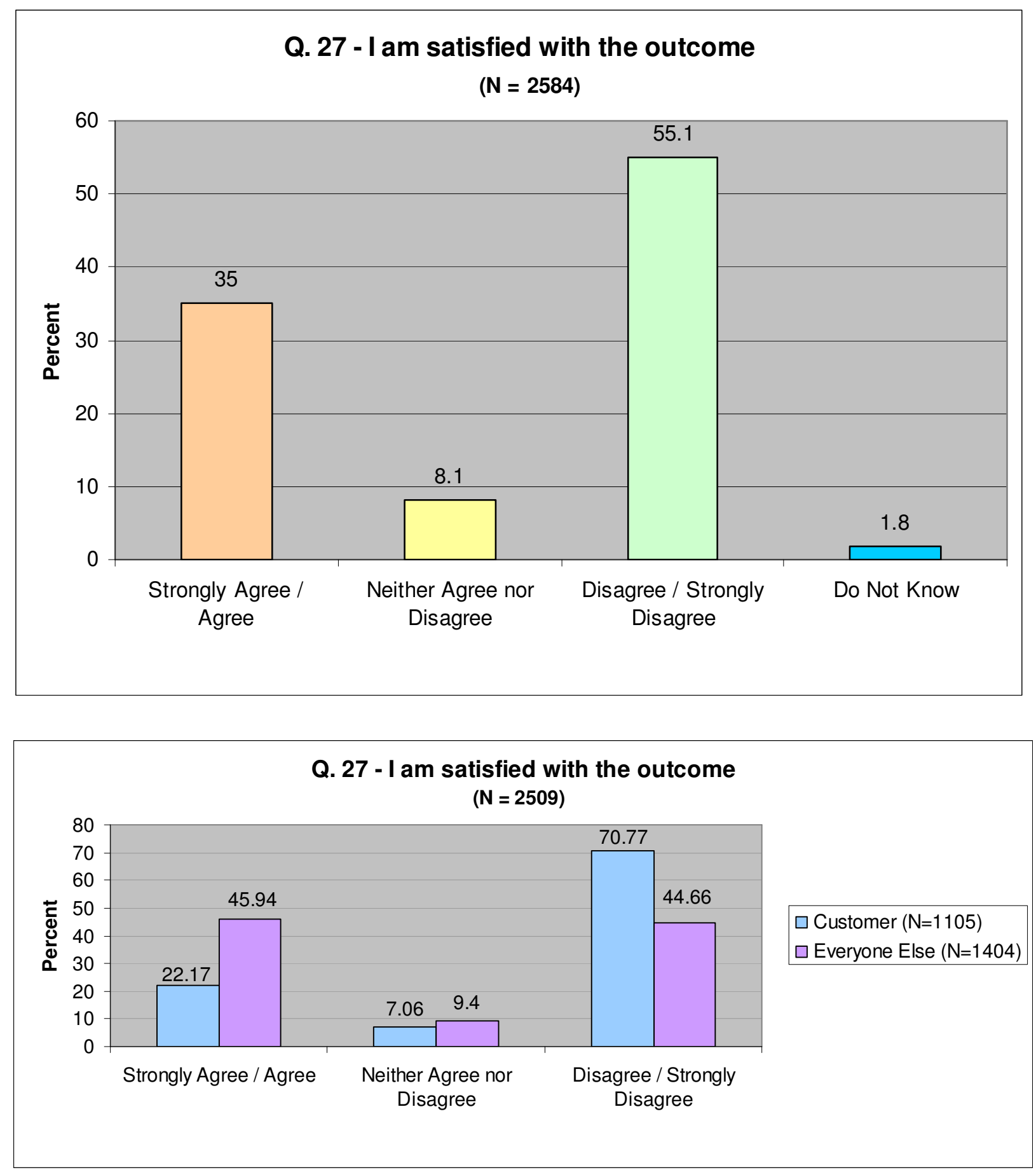

While 35\% of all survey participants agreed with the statement that "I am satisfied with the outcome," $22.17 \%$ of customers agreed with it. $55.1 \%$ of all survey participants disagreed with the statement, compared with $70.77 \%$ of all customers. ${ }^{58}$

\footnotetext{
${ }^{58}$ As expected, upon closer examination, a party's satisfaction rates tended to decrease in direct correlation to that party's degree of success in his/her most recent dispute as measured by his/her response to questions 11 (manner of resolution) and $12 \mathrm{~b}$ (percentage of damages originally claimed that were actually awarded).
} 

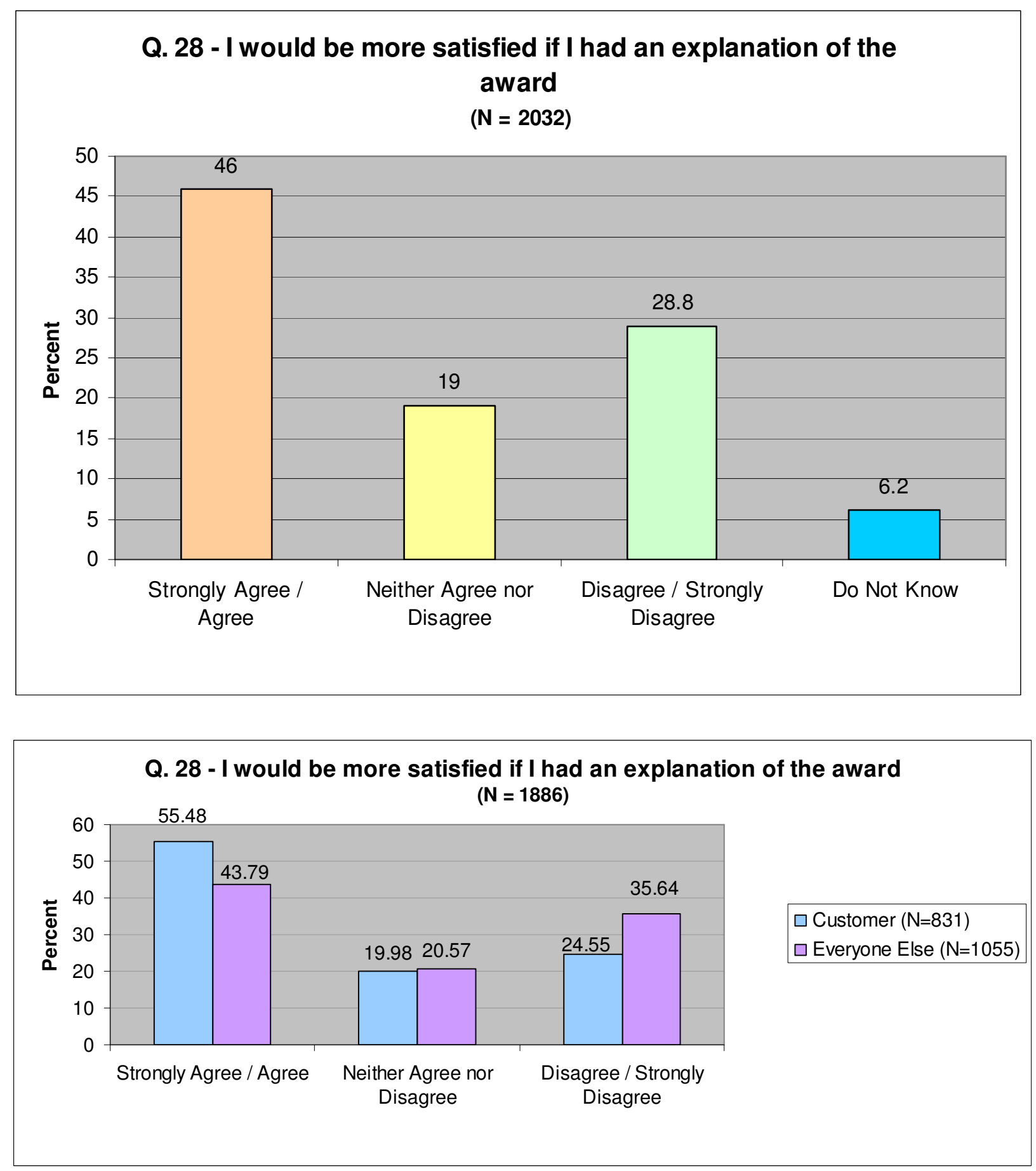

While $28.8 \%$ of all survey participants disagreed with the statement that "I would be more satisfied if I had an explanation of the award," $24.55 \%$ of customers disagreed with it. $46 \%$ of all survey participants agreed with the statement, compared to $55.48 \%$ of all customers. 

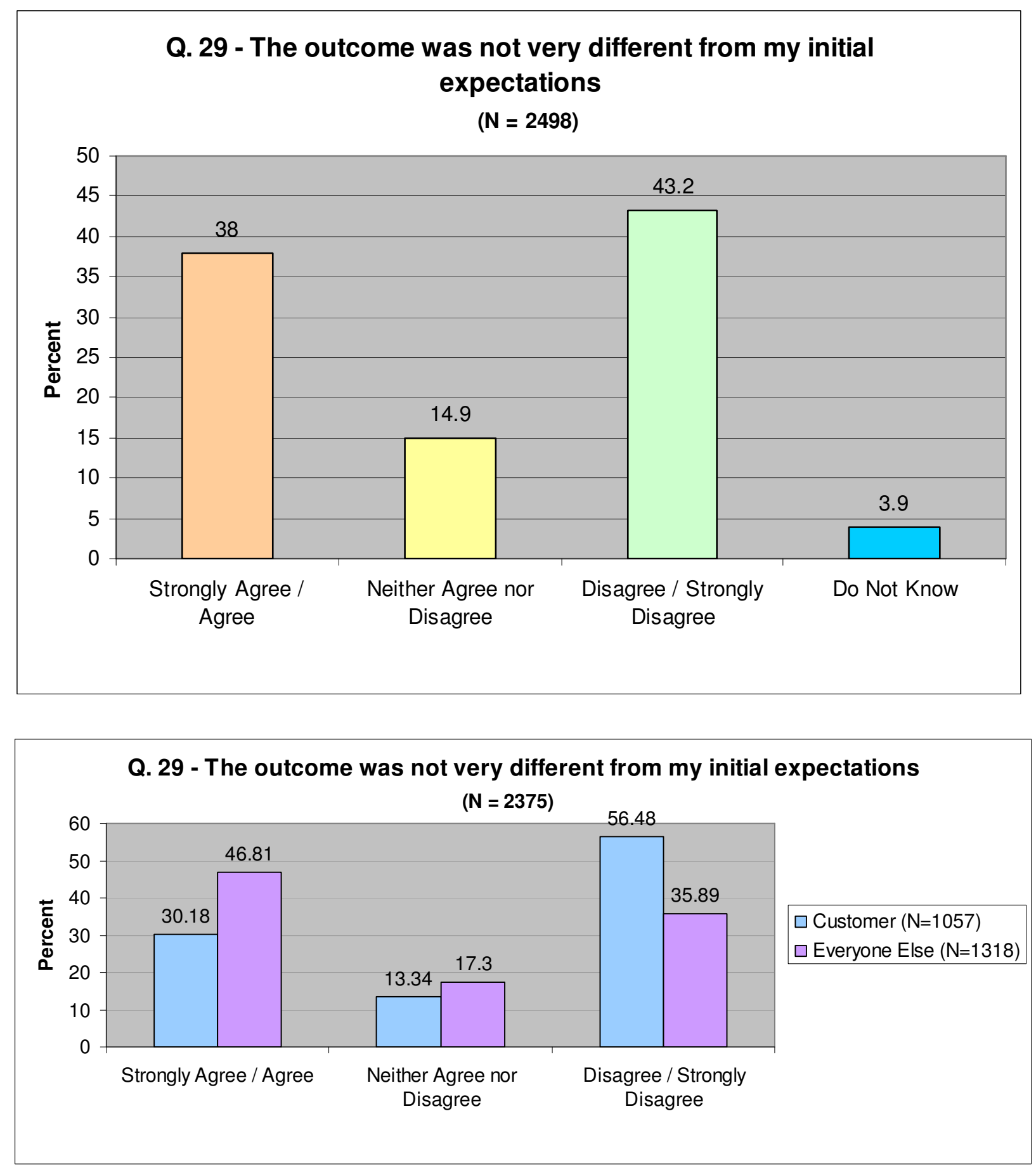

While $38 \%$ of all survey participants agreed with the statement that "the outcome was not very different from my initial expectation," $30.18 \%$ of customers agreed with it. $43.2 \%$ of all survey participants disagreed with the statement, compared with $56.48 \%$ of customers. 

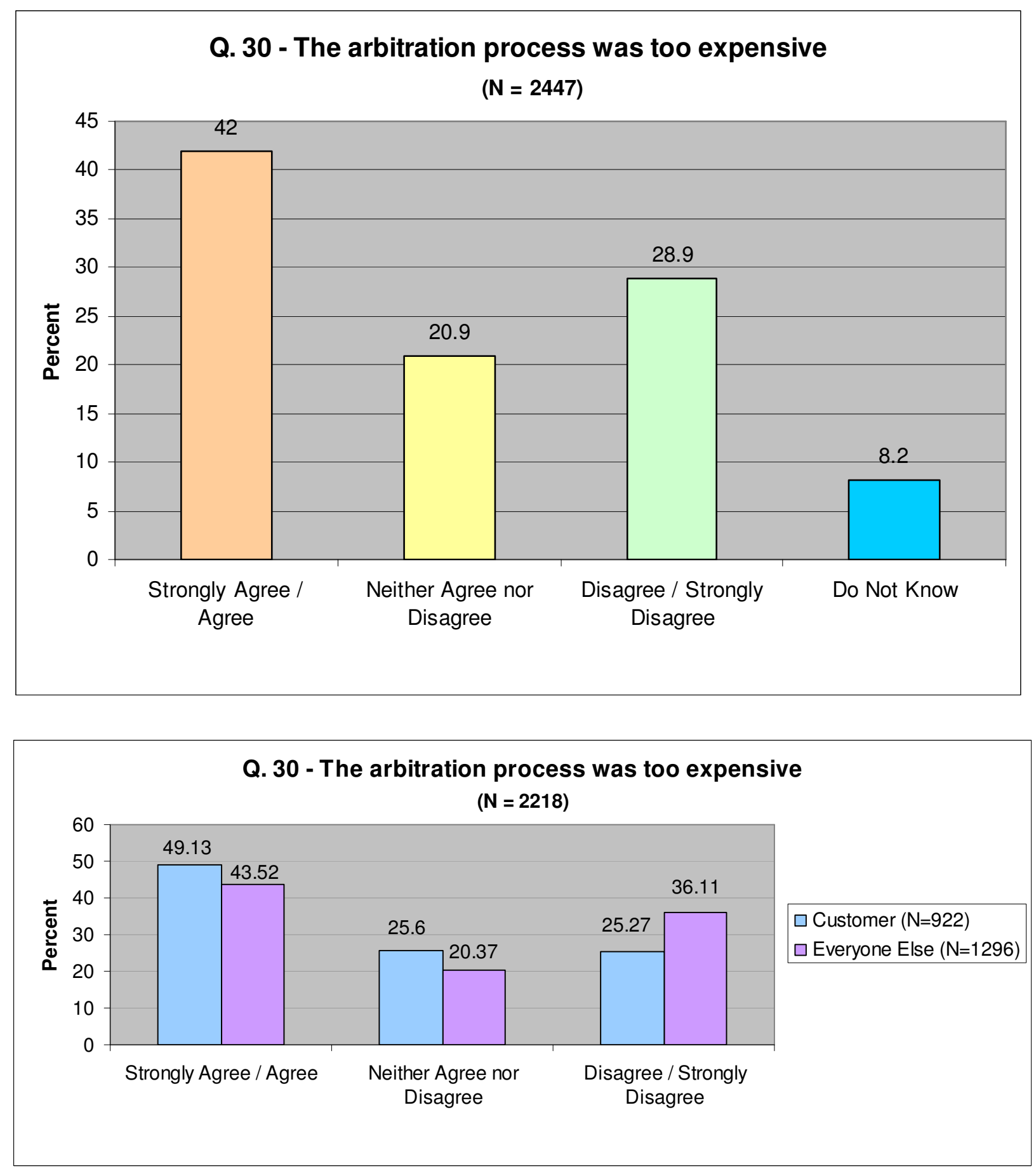

$28.9 \%$ of all survey participants disagreed with the statement that "the arbitration process was too expensive," and $25.27 \%$ of customers also disagreed with it. $42 \%$ of all survey participants agreed with the statement, compared to $49.13 \%$ of customers. 

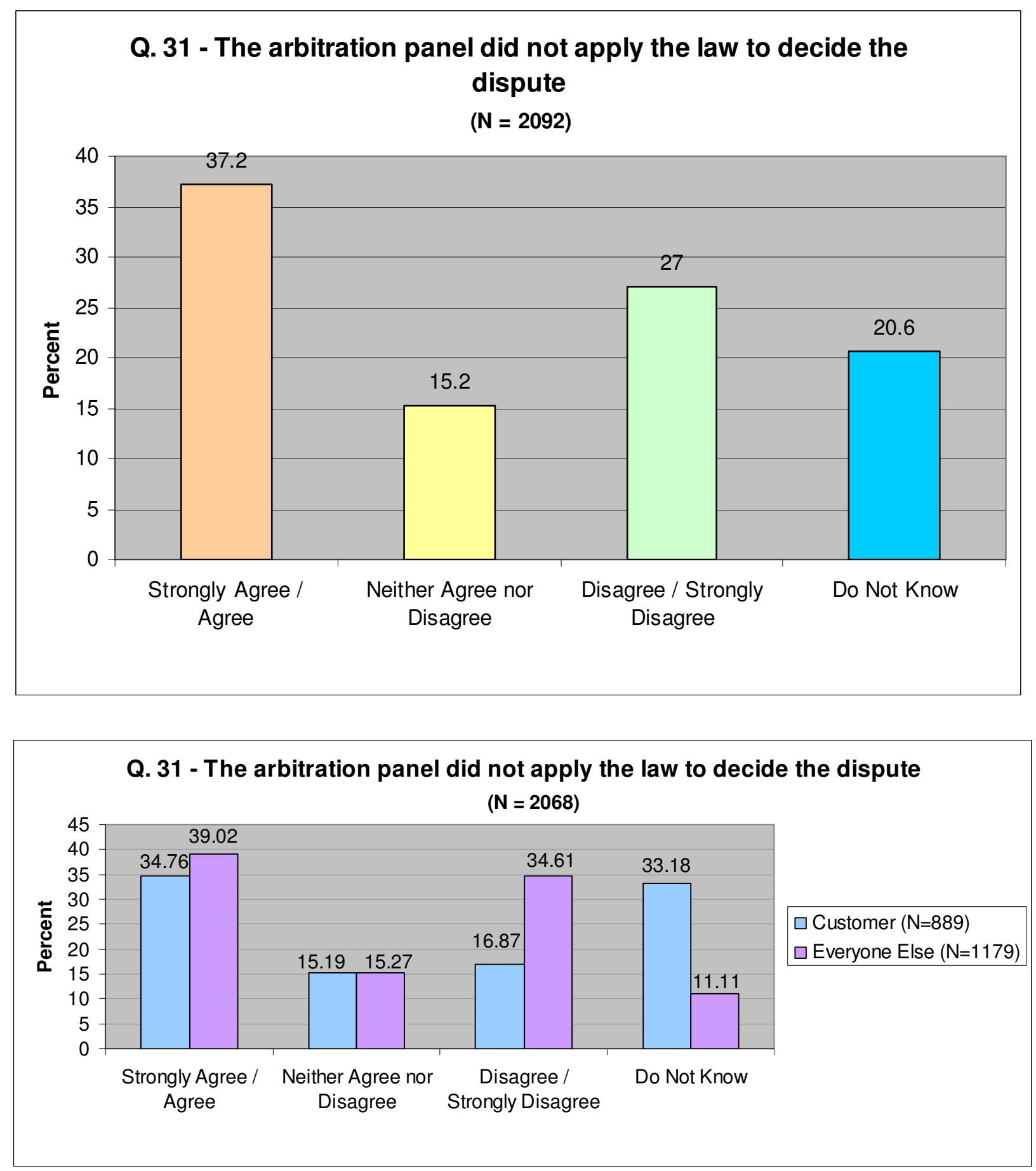

$27 \%$ of all survey participants disagreed with the statement that "the arbitration panel did not apply the law to decide the dispute," compared to $16.87 \%$ of customers. $37.2 \%$ of all survey participants agreed with the statement, compared with $34.76 \%$ of customers. Another $20.6 \%$ of survey participants said they did not know, compared with $33.18 \%$ of customers. 

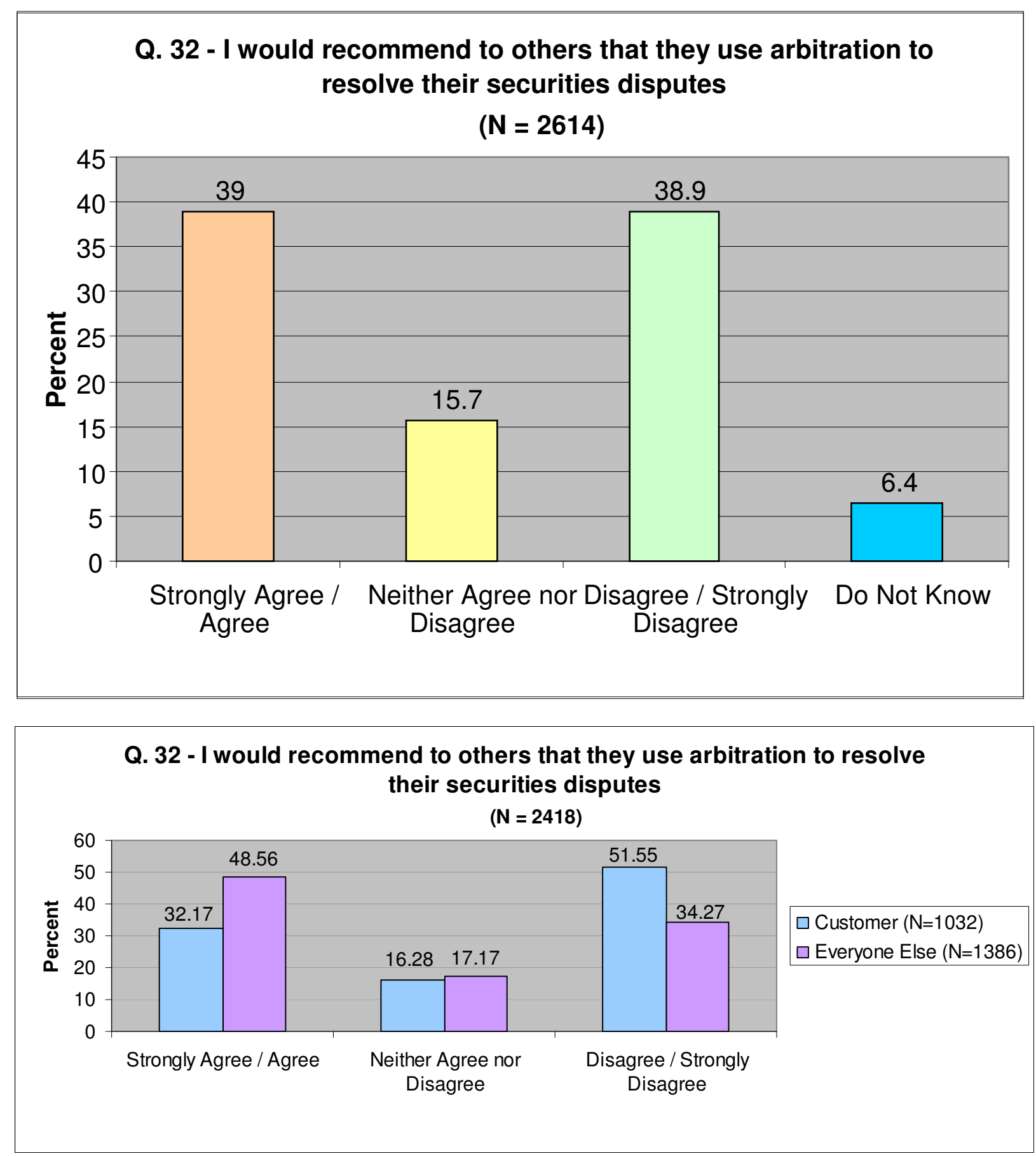

While $39 \%$ of all survey participants agreed with the statement that "I would recommend to others that they use arbitration to resolve their securities disputes," $32.17 \%$ of customers agreed with it. $38.9 \%$ of all survey participants disagreed with the statement, compared with $51.55 \%$ of customers. 

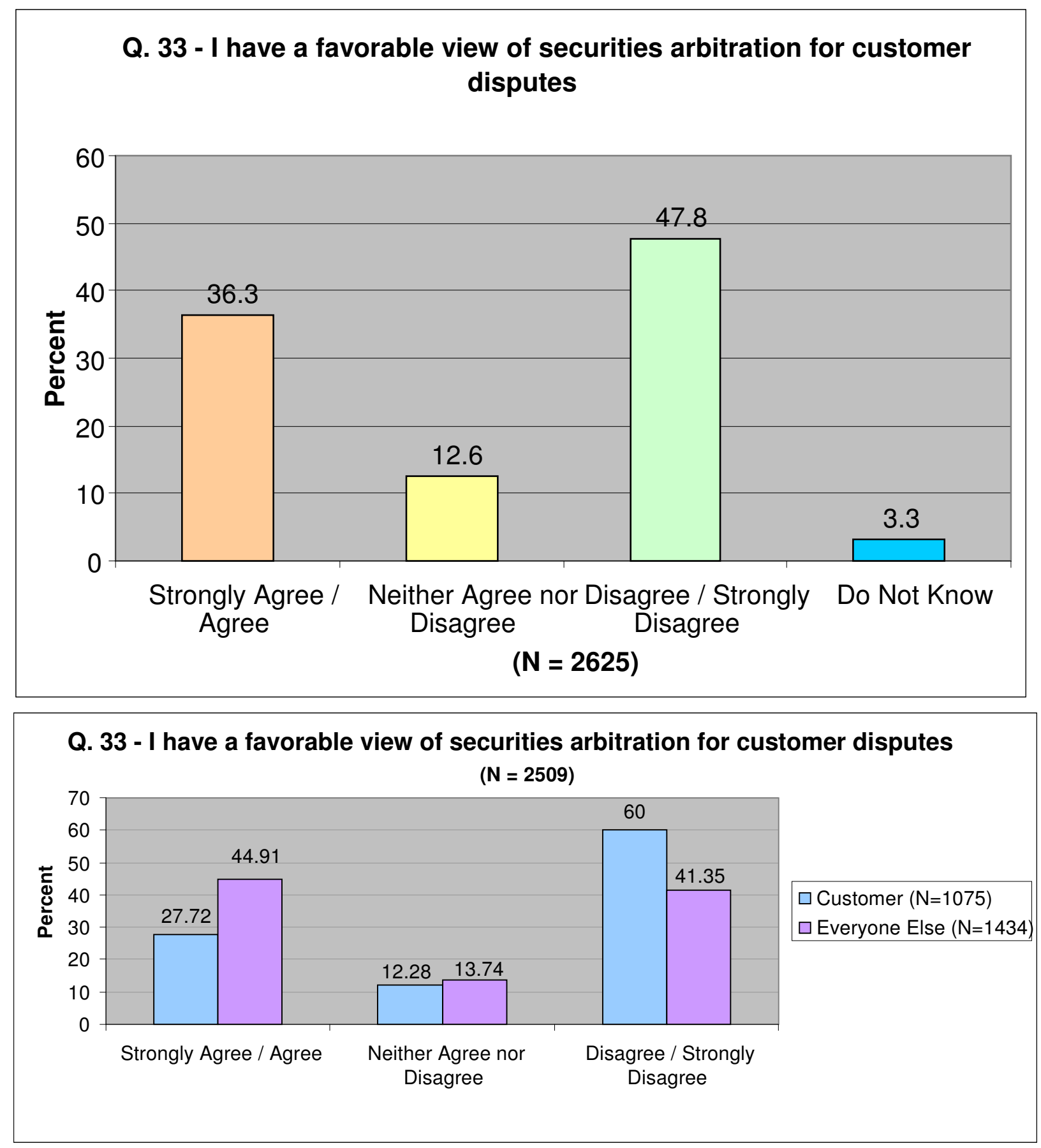

While $36.3 \%$ of all survey participants agreed with the statement that "I have a favorable view of securities arbitration for customer disputes," $27.72 \%$ of customers agreed with it. $47.8 \%$ of all survey participants disagreed with the statement; $60 \%$ of customers disagreed with it. 

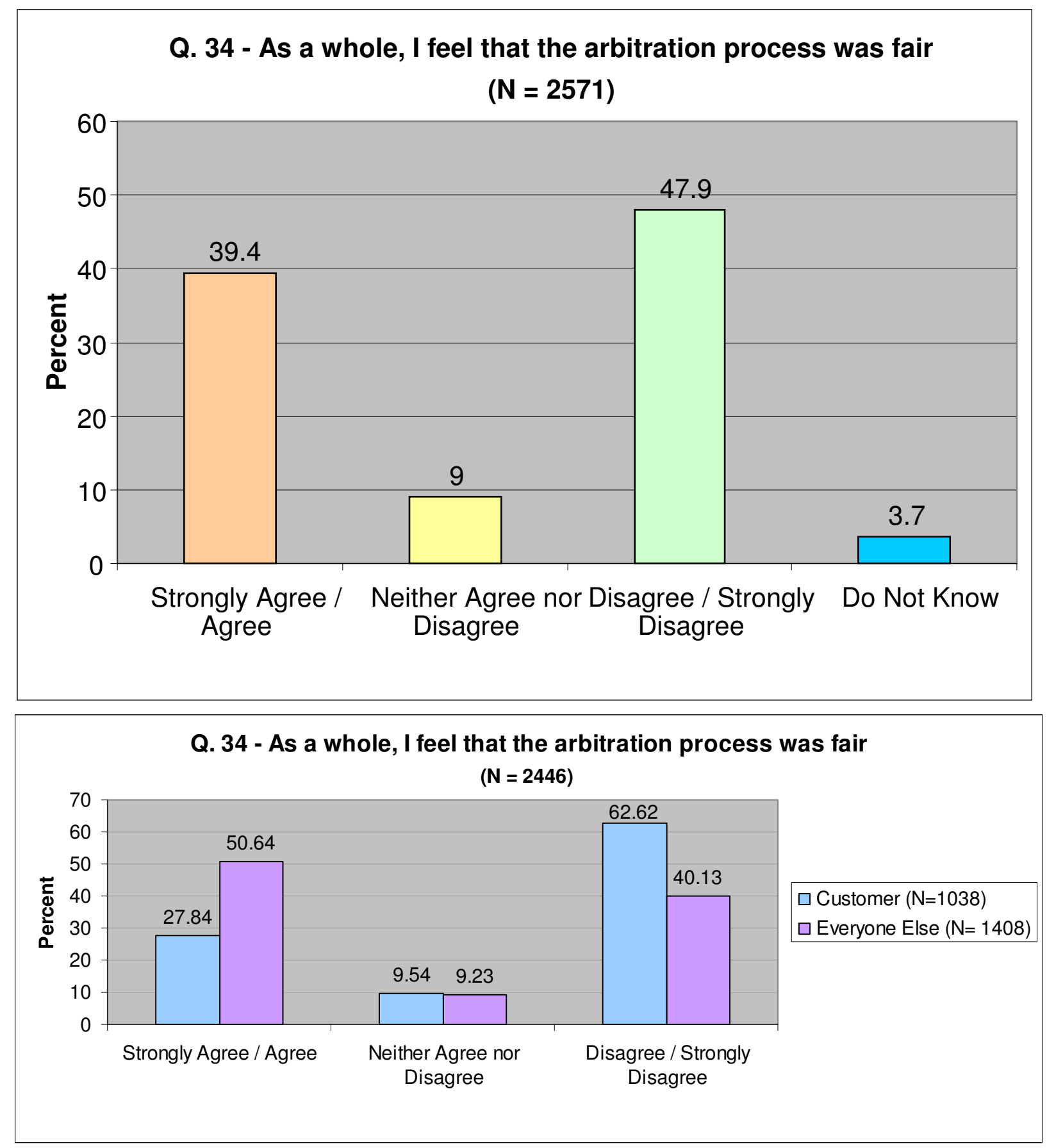

While $39.4 \%$ of all survey participants agreed with the statement that "as a whole, I feel the arbitration process was fair," $27.84 \%$ of customers agreed with it. $47.9 \%$ of all survey participants disagreed with the statement, compared to $62.62 \%$ of customers. 


\section{H. Arbitration vs. litigation}

Question 35 asked survey participants if, in the last five years, they had been a party or represented a party in at least one civil court case (not involving a criminal, matrimonial or custodial matter and excluding class action lawsuits). Of the total responses (3024), 59.6\% (1,802 responses) said no. The others (1,222 responses) stated their involvement as follows: ${ }^{59}$

\begin{tabular}{|l|l|l|}
$\begin{array}{l}\text { Q35: Nature of } \\
\text { involvement in a civil } \\
\text { case }\end{array}$ & $\begin{array}{l}\text { Number of survey } \\
\text { participants who selected this } \\
\text { response }\end{array}$ & $\begin{array}{l}\text { Percentage of survey } \\
\text { participants who answered this } \\
\text { question }\end{array}$ \\
\hline $\begin{array}{l}\text { None } \\
1,802\end{array}$ & 59.6 \\
\hline $\begin{array}{l}\text { Plaintiff in civil case } \\
\begin{array}{l}\text { Represented plaintiff in } \\
\text { civil case }\end{array}\end{array}$ & 195 & 6.4 \\
\hline $\begin{array}{l}\text { Defendant in civil case } \\
\text { Represented defendant } \\
\text { in civil case }\end{array}$ & 140 & 18.6 \\
\hline $\begin{array}{l}\text { Do not know/do not } \\
\text { recall }\end{array}$ & 585 & 4.6 \\
\hline
\end{tabular}

The survey directed those survey participants who indicated they were involved in a civil case in the last five years to answer questions $35 \mathrm{a}$ and $35 \mathrm{~b}$, which asked them to compare their experiences in court and arbitration. Question 35a (1,084 responses) instructed survey participants to focus on their most recent experience in a civil court case and asked how different they thought the result from the arbitration would have been had it proceeded in court.

\begin{tabular}{|l|l|l|l|}
$\begin{array}{l}\text { Q35a: How } \\
\text { different in court }\end{array}$ & $\begin{array}{l}\text { Number of survey } \\
\text { participants who } \\
\text { selected this } \\
\text { response }\end{array}$ & $\begin{array}{l}\text { Percentage of survey } \\
\text { participants who } \\
\text { answered this question } \\
(\mathbf{N}=1,084)\end{array}$ & $\begin{array}{l}\text { Percentage of } \\
\text { customer survey } \\
\text { participants who } \\
\text { answered this } \\
\text { question } \\
\text { (N=168) }\end{array}$ \\
\hline Very different & 539 & 49.7 & 51.8 \\
\hline A little different & 236 & 21.8 & 14.29 \\
\hline Exactly the same & 131 & 12.1 & 4.17 \\
\hline Do not know & 178 & 16.4 & 29.8 \\
\hline
\end{tabular}

\footnotetext{
${ }^{59}$ The totals add up to more than 1,222 because this question directed survey participants to select all that applied.
} 
Question 35b (1,088 responses) asked those same survey participants about the fairness of securities arbitration as compared to their most recent experience in a civil court case. While $30.9 \%$ found arbitration "very fair" or "somewhat fair," another $48.9 \%$ found arbitration "very unfair" or "somewhat unfair." In contrast, only $17 \%$ of customer-survey participants found arbitration "very fair" or "somewhat fair," and a striking $75.55 \%$ of customers found arbitration "very unfair" or "somewhat unfair."

\begin{tabular}{|l|l|l|l|}
$\begin{array}{l}\text { Q35b: How fair is } \\
\text { securities arbitration } \\
\text { as compared to } \\
\text { court? }\end{array}$ & $\begin{array}{l}\text { Number of survey } \\
\text { participants who } \\
\text { selected this } \\
\text { response }\end{array}$ & $\begin{array}{l}\text { Percentage of } \\
\text { survey } \\
\text { participants } \\
\text { who answered } \\
\text { this question } \\
\text { (N=1,088) }\end{array}$ & $\begin{array}{l}\text { Percentage of } \\
\text { customer survey } \\
\text { participants who } \\
\text { answered this question } \\
\text { (N=135) }\end{array}$ \\
\hline Very fair & 196 & 18.0 & 9.63 \\
\hline Somewhat fair & 140 & 12.9 & 7.41 \\
\hline Equally fair & 149 & 13.7 & 7.41 \\
\hline Somewhat unfair & 197 & 18.1 & 12.59 \\
\hline Very unfair & 335 & 30.8 & 62.96 \\
\hline Do not know & 71 & 6.5 & N/A \\
\hline
\end{tabular}

Question 36 asked all survey participants if, based on their experiences in one or more customer arbitrations, given the choice, they would choose arbitration to resolve a customer dispute in the future. $35.6 \%(1,077)$ said they would. In contrast, $29 \%$ (877) said they would not because arbitration is unfair. The breakdown of all responses, as well as by customer-survey participants, is as follows: ${ }^{62}$

\footnotetext{
${ }^{60}$ The number of customer survey participants who answered this question is far lower than the total number of survey participants who answered this question, thus making the comparisons between the two less meaningful.

${ }^{61}$ The number of customer survey participants who answered this question is far lower than the total number of survey participants who answered this question, thus making the comparisons between the two less meaningful.

${ }^{62}$ The question directed survey participants to select all that applied.
} 


\begin{tabular}{|c|c|c|c|}
\hline $\begin{array}{l}\text { Q36: Would you choose } \\
\text { arbitration in the future? }\end{array}$ & $\begin{array}{l}\text { Number of survey } \\
\text { participants who } \\
\text { selected this } \\
\text { response }\end{array}$ & $\begin{array}{l}\text { Percentage of } \\
\text { survey } \\
\text { participants } \\
\text { who answered } \\
\text { this question }\end{array}$ & $\begin{array}{l}\text { Percentage of } \\
\text { customer survey } \\
\text { participants who } \\
\text { answered this } \\
\text { question } \\
(\mathrm{N}=1359)\end{array}$ \\
\hline $\begin{array}{l}\text { I would choose arbitration } \\
\text { over court }\end{array}$ & 1,077 & 35.6 & 24.65 \\
\hline $\begin{array}{l}\text { I would not choose arbitration } \\
\text { because it is not fair }\end{array}$ & 877 & 29.0 & 34.81 \\
\hline Not sure & 606 & 20.0 & 25.75 \\
\hline $\begin{array}{l}\text { I would not choose arbitration } \\
\text { because the arbitrators are } \\
\text { not competent to resolve } \\
\text { customer-broker disputes }\end{array}$ & 476 & 15.7 & 16.19 \\
\hline $\begin{array}{l}\text { I would not choose arbitration } \\
\text { because it is more expensive }\end{array}$ & 220 & 7.3 & 6.18 \\
\hline None of the above & 153 & 5.1 & $\mathrm{~N} / \mathrm{A}$ \\
\hline $\begin{array}{l}\text { I would not choose arbitration } \\
\text { because it takes more time }\end{array}$ & 134 & 4.4 & 4.5 \\
\hline
\end{tabular}

We then asked, in question 37 (2,888 responses), all survey participants whether they were familiar with procedural rule changes made by the forums in the past five years. $64.3 \%$ $(1,858)$ were not familiar with the changes. Of those who indicated familiarity with the changes (1,030), $30.6 \%$ said that the changes have made the process fairer; $51.7 \%$ said the changes have not made a difference; and $17.7 \%$ said the changes made the process less fair. ${ }^{63}$

\footnotetext{
${ }^{63}$ For this question, we did not provide the responses for customers only because there were so few customers who were familiar with the rule changes.
} 


Q37: Are you familiar with
forum rule changes in past 5
years?
No, I am not familiar with the
changes
Yes, I think the changes have not
made a difference
Yes, I think the changes have
made the process fairer
Yes, I think the changes have
made the process less fair

Number of survey participants who selected this response $(\mathrm{N}=2,888)$

1858

533

315

182
Percentage of total survey participants who answered this question

64.3

18.5

10.9

6.3

\section{Overall perceptions of arbitration}

Finally, question 38 asked all survey participants the extent to which they agreed or disagreed with four statements regarding the securities arbitration process.

\section{Question 38}

In your opinion, do you believe that the securities arbitration process is conducted by the arbitrators in a way that is:

(number of survey participants who selected this response/percentage of survey participants who answered this question)

\begin{tabular}{|l|l|l|l|l|l|l|}
\hline & $\begin{array}{l}\text { Q38 } \\
\text { agree }\end{array}$ & Agree & $\begin{array}{l}\text { Neither } \\
\text { agree nor } \\
\text { disagree }\end{array}$ & Disagree & $\begin{array}{l}\text { Strongly } \\
\text { disagree }\end{array}$ & $\begin{array}{l}\text { Don't } \\
\text { know }\end{array}$ \\
\hline $\begin{array}{l}\text { a. Simple for all } \\
\text { parties involved } \\
\text { (2,861 responses) }\end{array}$ & $267 / 9.3$ & $961 / 33.6$ & $467 / 16.3$ & $562 / 19.6$ & $386 / 13.5$ & $218 / 7.6$ \\
\hline $\begin{array}{l}\text { b. Fair to all parties } \\
\text { involved } \\
\text { (2,870 responses) }\end{array}$ & $281 / 9.8$ & $681 / 23.7$ & $323 / 11.3$ & $573 / 20.0$ & $781 / 27.2$ & $231 / 8.0$ \\
\hline $\begin{array}{l}\text { c. Economical } \\
\text { (2,854 responses) }\end{array}$ & $216 / 7.6$ & $800 / 28.0$ & $538 / 18.9$ & $595 / 20.8$ & $422 / 14.8$ & $283 / 9.9$ \\
\hline $\begin{array}{l}\text { d. Without bias } \\
\text { (2,856 responses) }\end{array}$ & $279 / 9.8$ & $594 / 20.8$ & $377 / 13.2$ & $534 / 18.7$ & $740 / 25.9$ & $332 / 11.6$ \\
\hline
\end{tabular}


When we combine the "strongly agree" and "agree" categories, as well as the "strongly disagree" and "disagree" categories, the distribution of responses is as follows:

\section{Arbitration is conducted by the arbitrators in a way that is:}

Simple

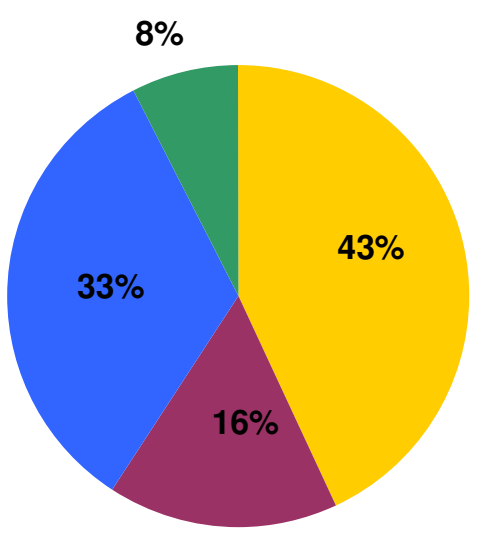

Economical for all parties involved

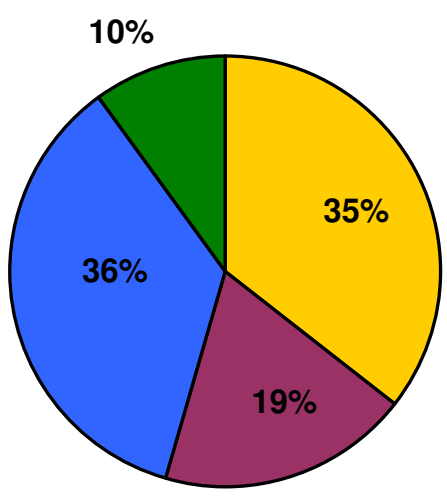

Fair to all parties
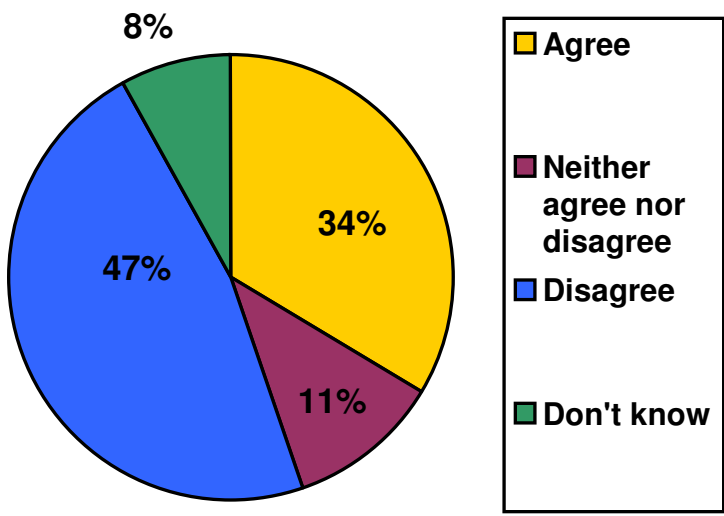

Don't know

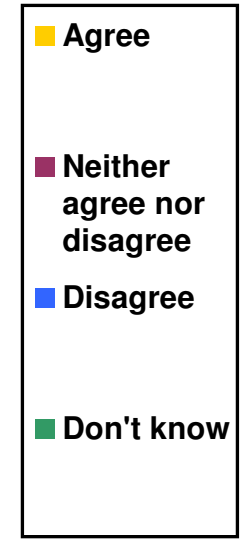

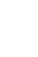


The next-fewest number of survey participants neither agreed nor disagreed with that statement (13\%), and more survey participants disagreed (44\%) than agreed (31\%) with that statement.

In contrast, $19 \%$ neither agreed nor disagreed with the statement that the process is economical, and the responses were just about equally divided (35-36\%) between the "agree" and "disagree" categories. $16 \%$ neither agreed nor disagreed with the statement that the process is simple, and more survey participants agreed (43\%) than disagreed (33\%) with the statement. We then isolated the customer-survey participants' answers to the four statements in the subparts of question 38 as compared to the answers of all other survey participant types. For all four questions, the customers' responses were different from the responses of all other survey participants to a statistically significant degree. 

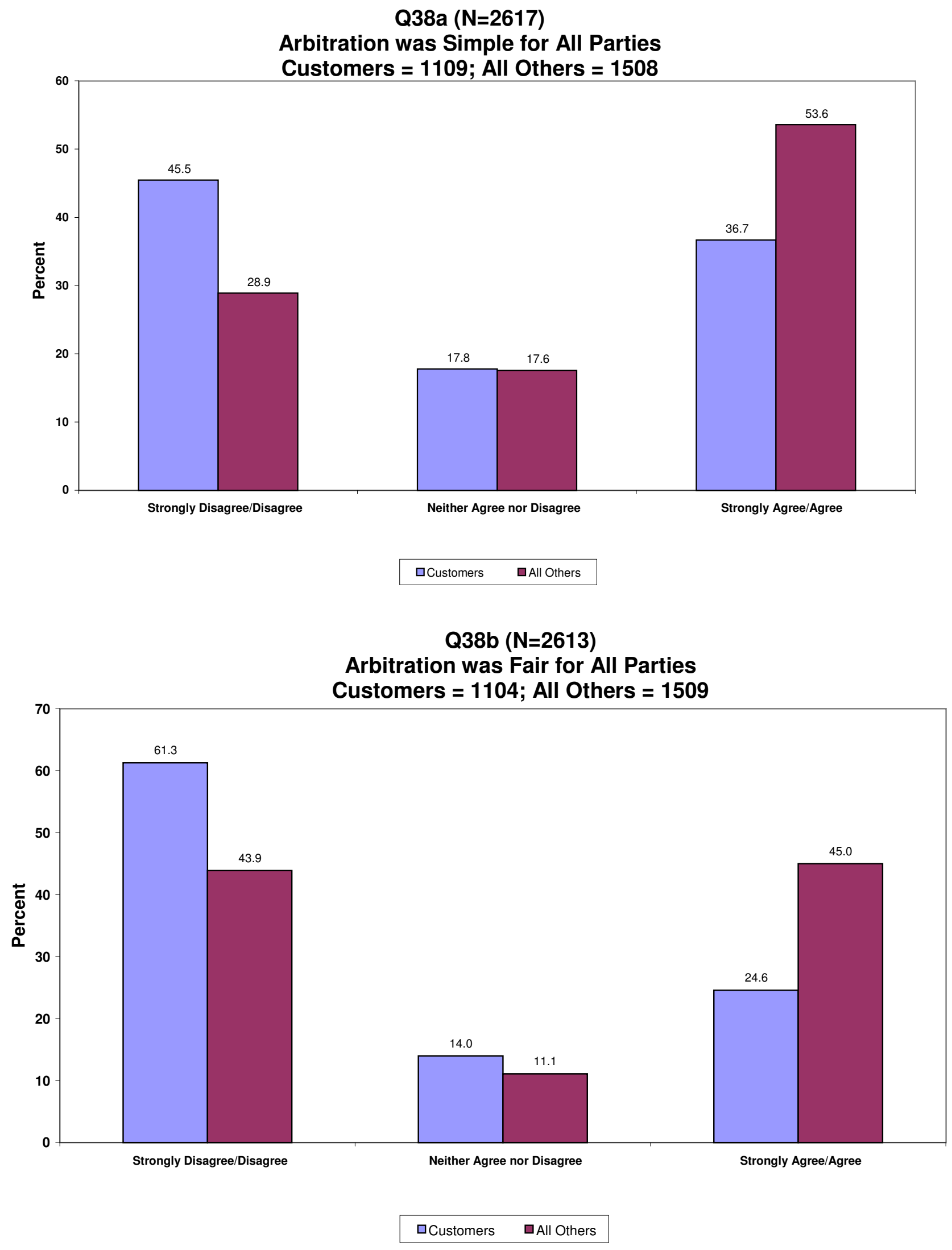
Q38c ( $\mathrm{N}=2824)$

Arbitration was Economical for All Parties

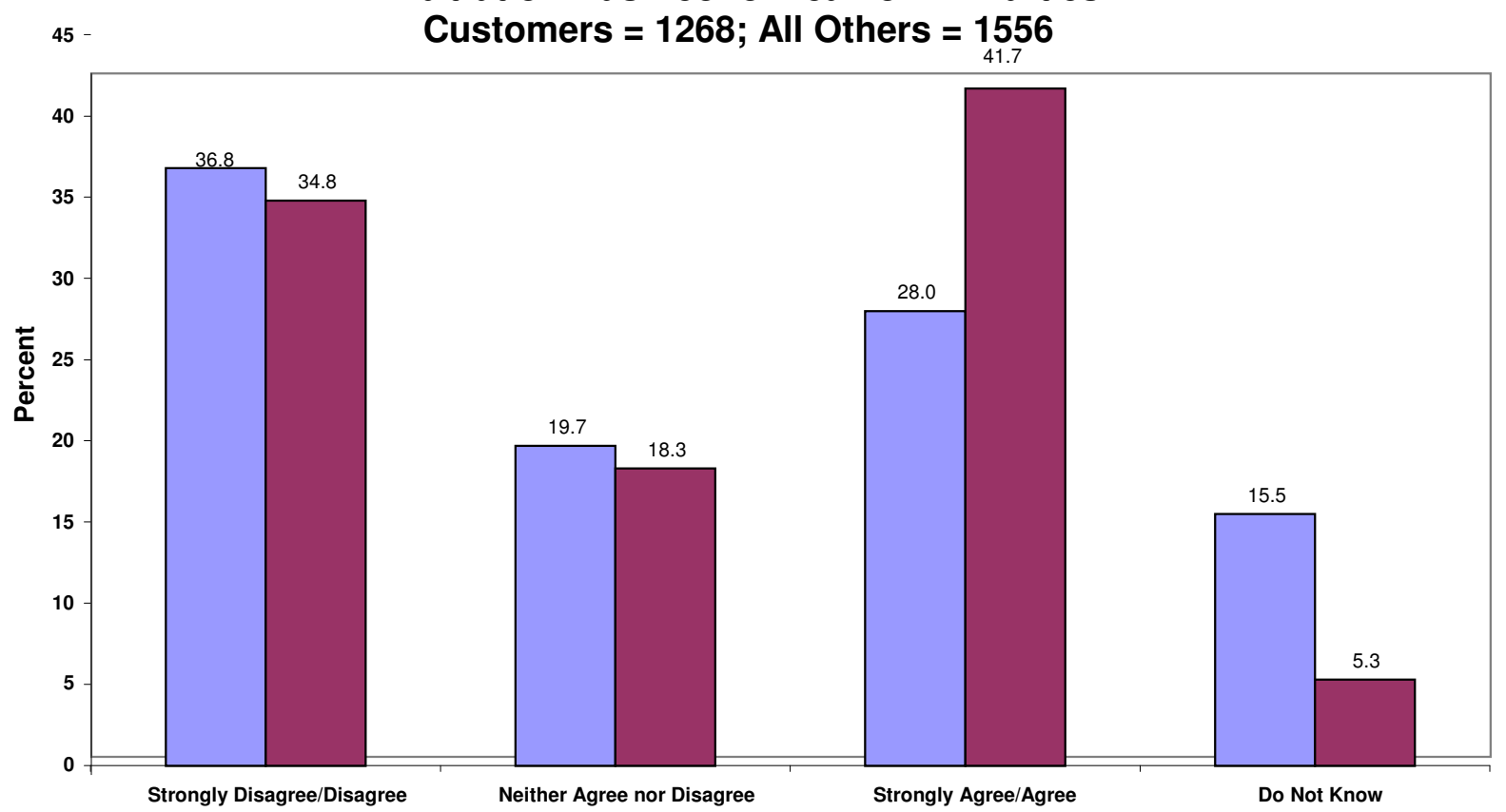

口Customers $\quad$ AAll Others

Q38d ( $\mathrm{N}=2826)$

Arbitration was Without Bias for All Parties

Customers = 1273; All Others = 1553

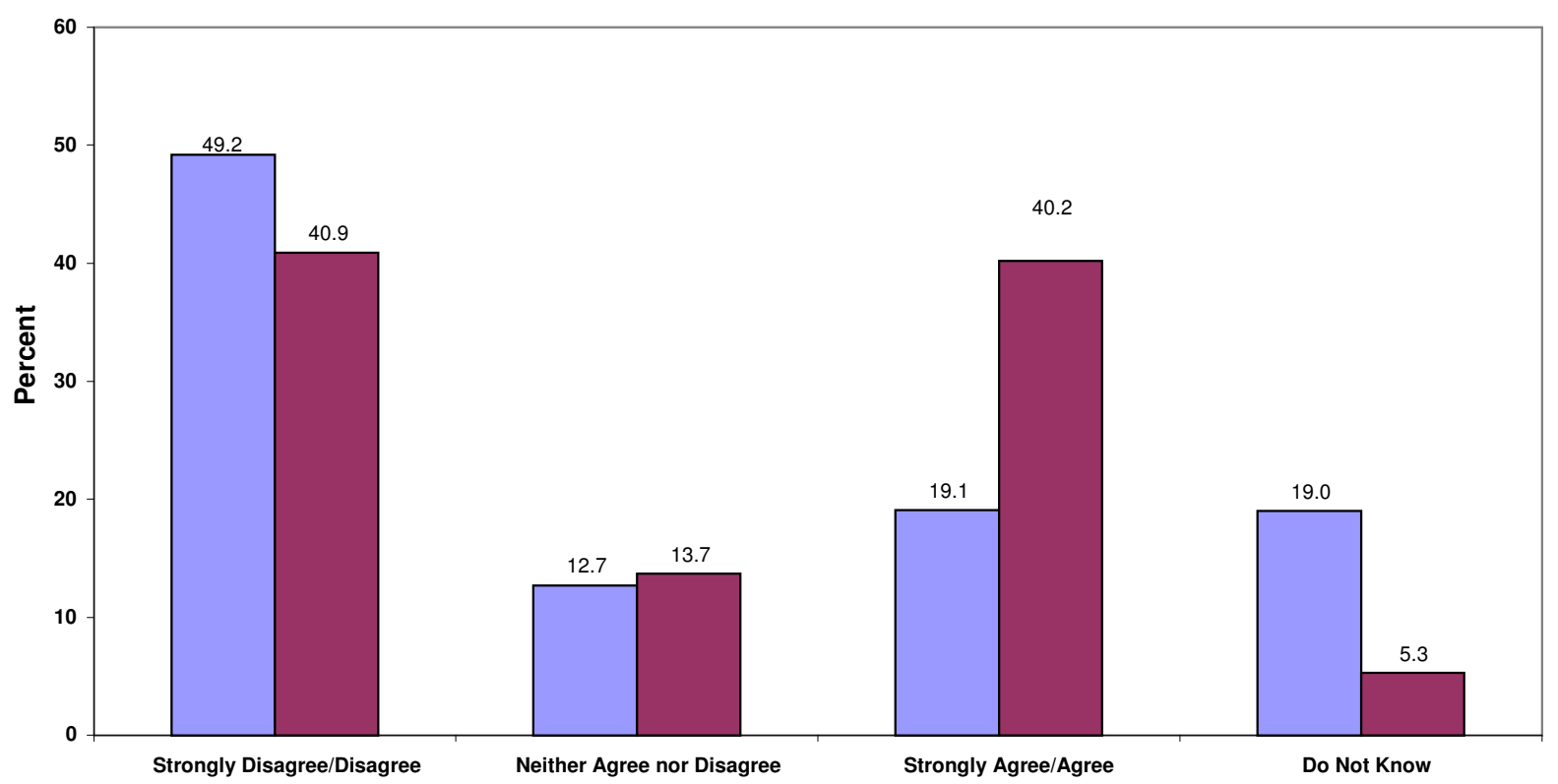

口Customers $\square$ All Others 


\section{J. Analysis of regional differences}

Finally, we analyzed the responses to various survey questions, sorted by region (specifically, the region of the hearing location of the survey participant's most recent arbitration). ${ }^{64}$ We report below our findings as to questions that yielded results that varied by region in a statistically significant way.

Q11-Analysis of Outcomes by Region. Overall, there was an award to the customer in $27.97 \%$ of responses, there was no award to the customer in $29.74 \%$ of responses, and the parties settled with or without a mediator in $42.29 \%$ of the responses. The Midwest was the only region with a higher "customer award" percentage (33.6\%); it had a correspondingly lower "no customer award" percentage (23.36\%) and a somewhat higher settlement percentage (43.14\%). The Northeast had the lowest "customer award" percentage (23.89\%); its "no award" percentage (30.19\%) was only slightly higher than the overall, and its settlement percentage (45.92\%) was the highest of any of the regions. The West had the highest "no customer award" percentage (34.08\%); its "customer award" percentage (27.14\%) was somewhat lower than the overall, and its settlement percentage (38.77\%) was lower than the overall. Finally, the Southeast had a $27.79 \%$ "customer award" percentage; a $30.33 \%$ "no customer award" percentage, and a $41.88 \%$ settlement percentage.

A chart of the percentages by region shows:

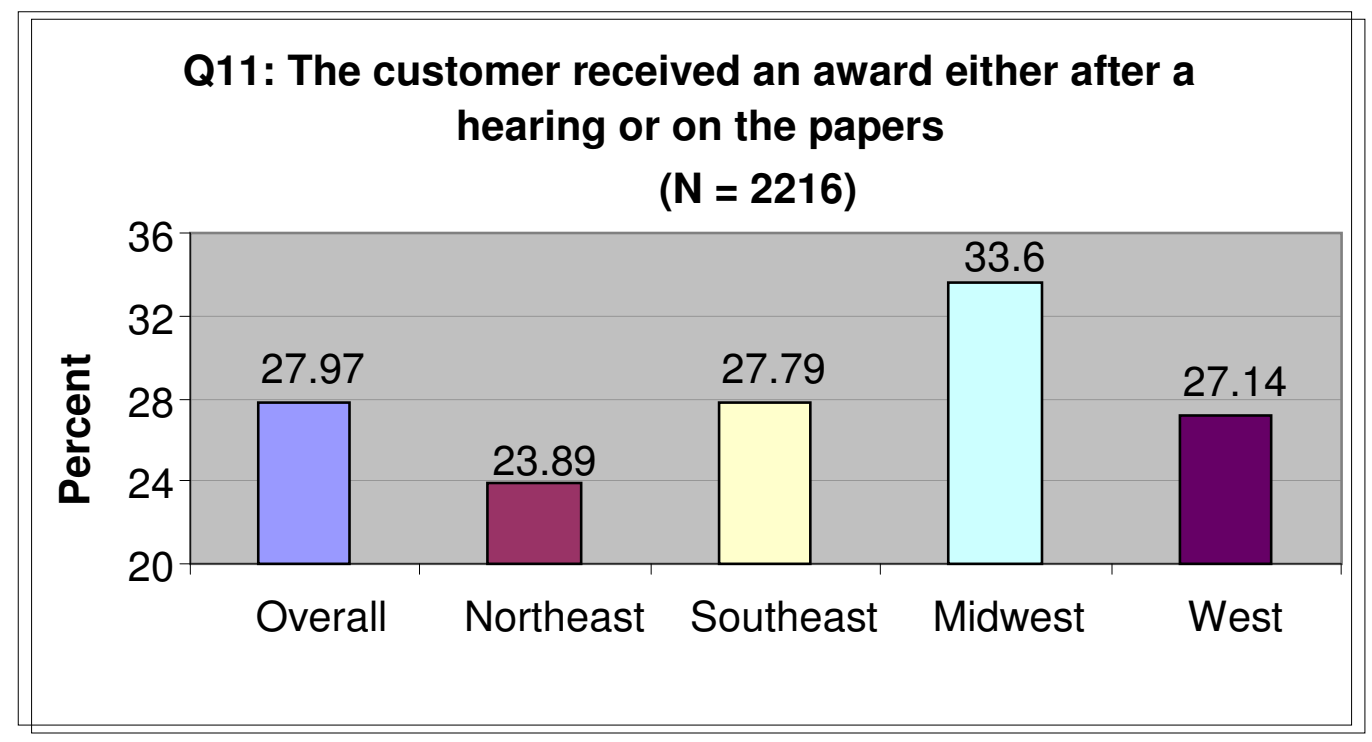

\footnotetext{
${ }^{64}$ The following analysis excludes the 208 responses indicating the most recent dispute was resolved in a Simplified Arbitration ("paper case").
} 

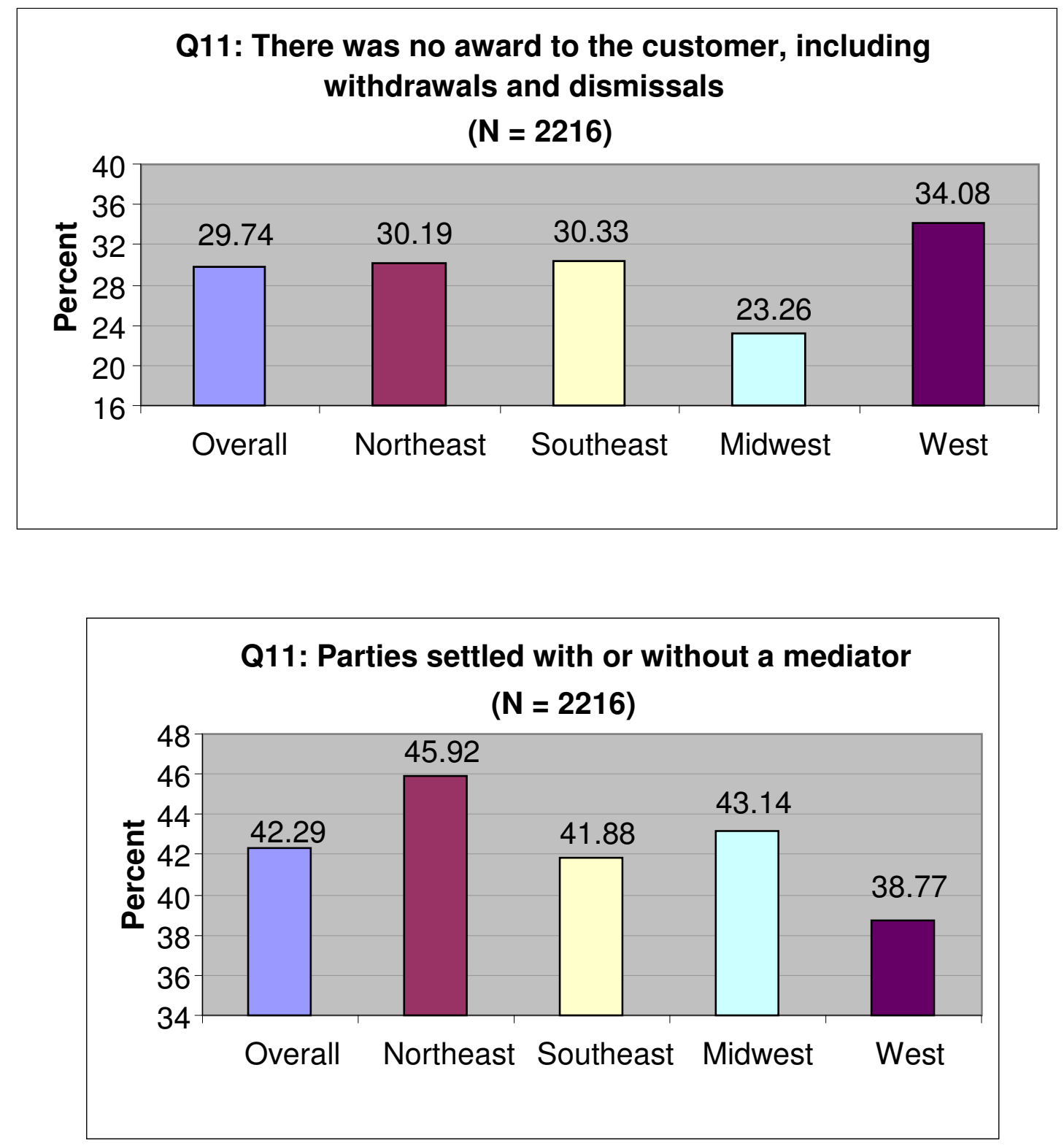
Q12a-Analysis of the amount of award by regions. The amount of the award overall and by region is as follows $(\mathrm{N}=600)$ :

\begin{tabular}{|l|l|l|l|l|l|}
\hline $\begin{array}{l}\text { Amount of } \\
\text { award }\end{array}$ & $\begin{array}{l}\text { Percentage of } \\
\text { survey } \\
\text { participants } \\
\text { who } \\
\text { answered this } \\
\text { question }\end{array}$ & $\begin{array}{l}\text { Percentage of } \\
\text { survey } \\
\text { participants - } \\
\text { Northeast }\end{array}$ & $\begin{array}{l}\text { Percentage of } \\
\text { survey } \\
\text { participants - } \\
\text { Southeast }\end{array}$ & $\begin{array}{l}\text { Percentage of } \\
\text { survey } \\
\text { participants - } \\
\text { Midwest }\end{array}$ & $\begin{array}{l}\text { Percentage of } \\
\text { survey } \\
\text { participants - } \\
\text { West }\end{array}$ \\
\hline $\begin{array}{l}\$ 1-10,000 \\
10 \%\end{array}$ & 14.96 & 10.27 & 8.54 & 7.36 \\
\hline $\begin{array}{l}\$ 10,001- \\
50,000\end{array}$ & $28.5 \%$ & 33.86 & 30.14 & 31.1 & 20.25 \\
\hline $\begin{array}{l}\$ 50,001- \\
250,000\end{array}$ & $40.17 \%$ & 37.8 & 34.25 & 42.68 & 44.79 \\
\hline $\begin{array}{l}\$ 250,001- \\
1,000,000\end{array}$ & $15.67 \%$ & 9.45 & 17.12 & 15.24 & 19.63 \\
\hline $\begin{array}{l}\text { More than } \\
\$ 1,000,000\end{array}$ & $5.67 \%$ & 3.94 & 8.22 & 2.44 & 7.98 \\
\hline
\end{tabular}

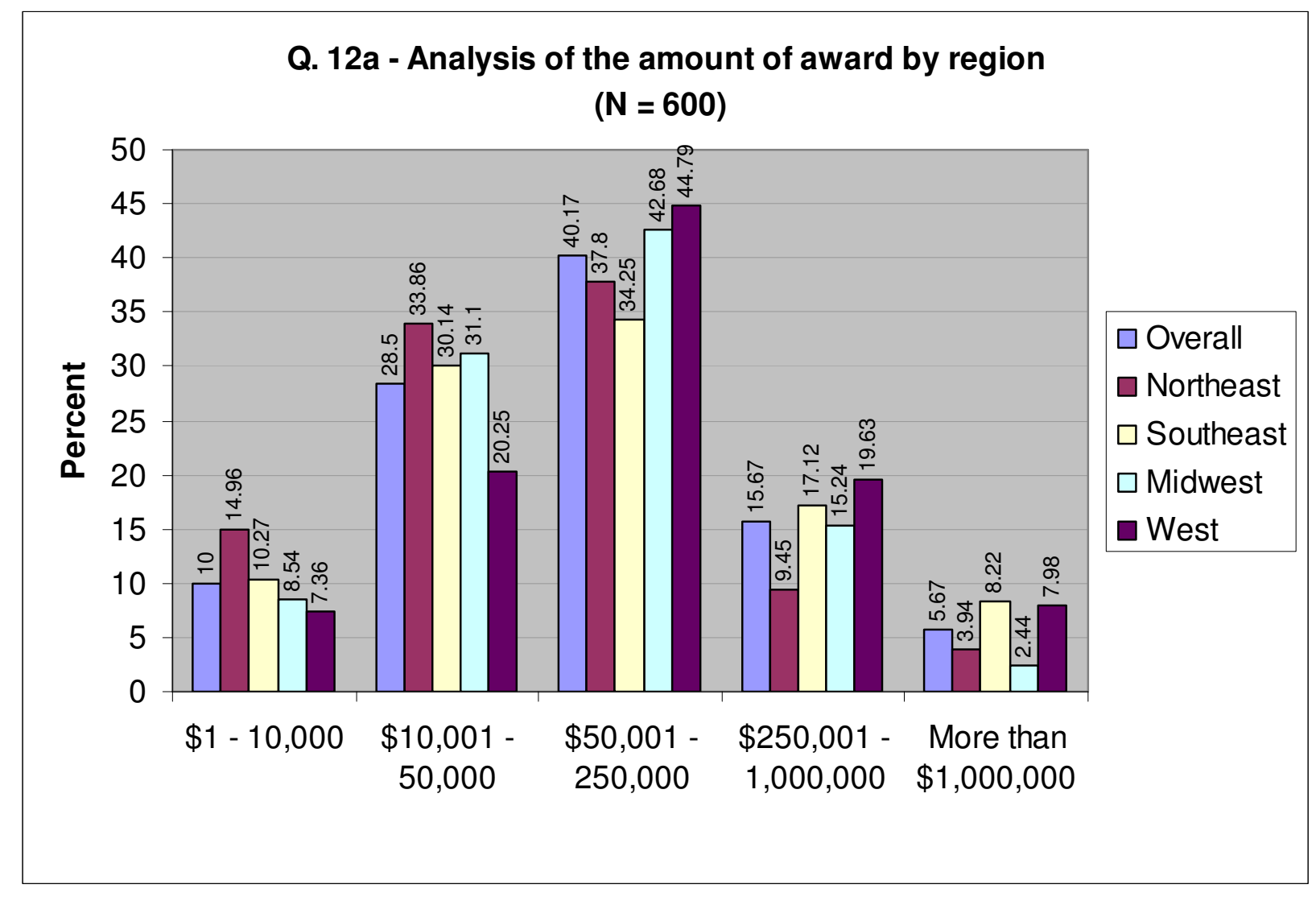




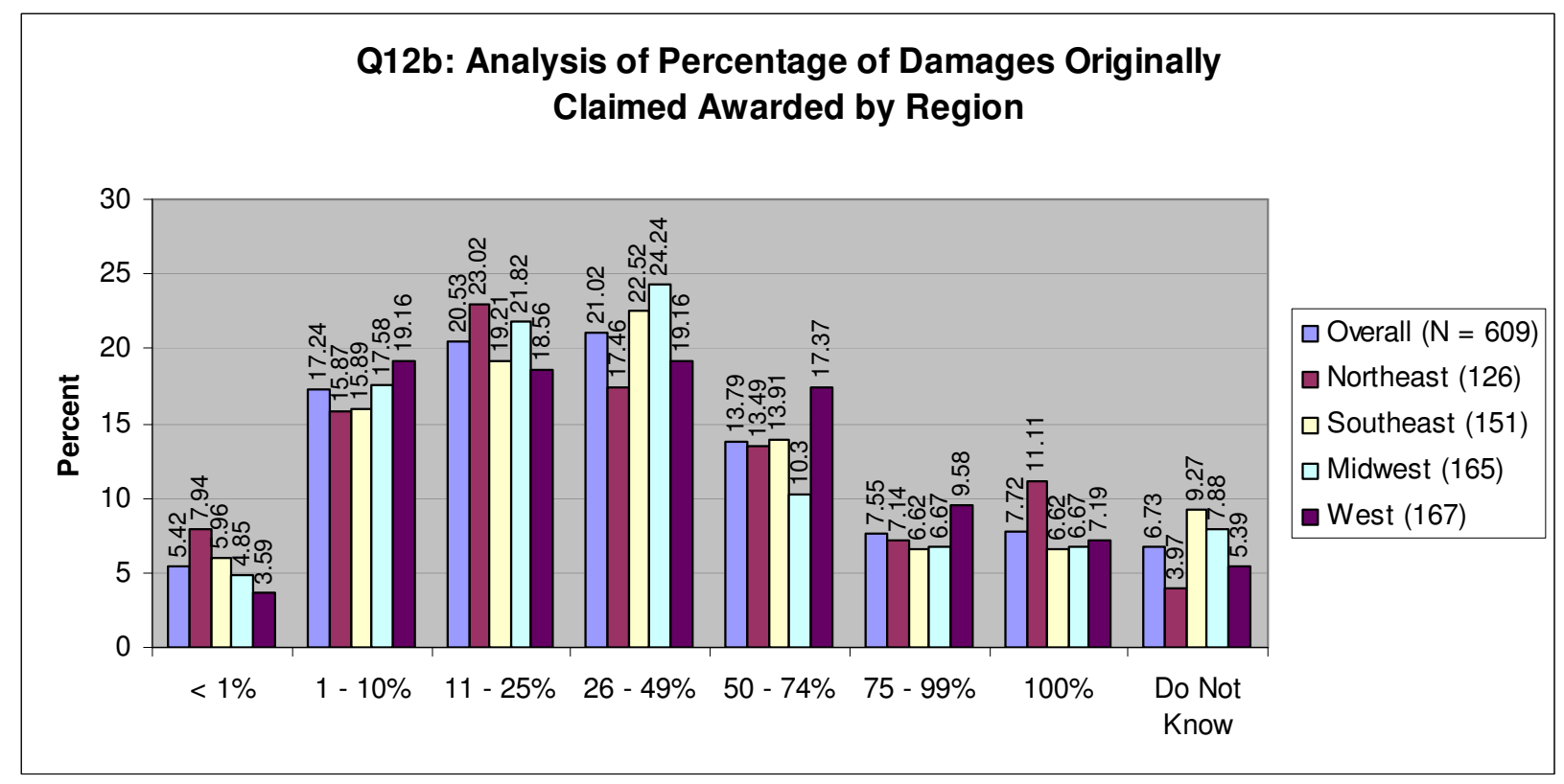

We also identified the following statistically significant differences in responses when sorted by region:

- Q14d: Survey participants from the Northeast region answered that the industry arbitrator appeared to favor at least one securities party at a higher rate than survey participants from the other regions. Thus, $24.44 \%$ of Northeast survey participants answered that the industry arbitrator appeared to favor at least one securities party, while $21.94 \%, 15.19 \%$ and $20.27 \%$ of survey participants from the Southeast, Midwest and Western regions, respectively, answered similarly.

- Q20: Survey participants from the Southeast region more frequently disagreed with the statement that the panel appeared competent to handle pre-hearing issues $(26.43 \%)$ than survey participants from the other regions $(20.69 \%, 21.73 \%$ and $19.35 \%$ for Northeast, Midwest and Western, respectively). $60.92 \%$ of Western survey participants agreed with the statement, whereas $52.18 \%, 52.01$ and $56.54 \%$ of survey participants from the Northeast, Southeast and Midwestern regions, respectively, agreed with the statement.

- Q30: Survey participants from the Western region more frequently disagreed with the statement that arbitration was too expensive (35.69\%) than survey participants in the other regions $(28.87 \%, 31.55 \%$ and $28.86 \%$ from the Northeast, Southeast and Midwest regions respectively). Conversely, survey participants from the Western region less frequently agreed with the statement that arbitration was too expensive $(37.84 \%)$ as compared with survey participants in the other regions $(48.36 \%, 48.93 \%$ and $49.5 \%$ of survey participants from the Northeast, Southeast and Midwest regions respectively).

- Q38: Survey participants from the Southeast and West more frequently agreed that arbitration is simple, fair, economical, and conducted without bias than survey participants in the Midwest and Northeast regions. The following charts illustrate the percentages: 
Q38a: The securities arbitration process is conducted by the arbitrators in a way that is simple for all parties involved

\begin{tabular}{|l|l|l|l|}
\hline $\begin{array}{l}\text { Percentage of survey } \\
\text { participants who answered this } \\
\text { question }\end{array}$ & Agree & Neither agree nor disagree & Disagree \\
\hline Northeast & 42.33 & 16.77 & 40.90 \\
\hline Southeast & 51.01 & 13.81 & 35.17 \\
\hline Midwest & 44.68 & 21.28 & 34.04 \\
\hline West & 48.9 & 19.46 & 31.64 \\
\hline
\end{tabular}

Q38b: The securities arbitration process is conducted by the arbitrators in a way that is fair to all parties involved

\begin{tabular}{|l|l|l|l|}
\hline $\begin{array}{l}\text { Percentage of survey } \\
\text { participants who answered this } \\
\text { question }\end{array}$ & Agree & $\begin{array}{l}\text { Neither agree nor } \\
\text { disagree }\end{array}$ & Disagree \\
\hline Northeast & 36.78 & 12.81 & 50.41 \\
\hline Southeast & 39.78 & 9.21 & 51.01 \\
\hline Midwest & 34.32 & 15.58 & 50.11 \\
\hline West & 39.86 & 12.33 & 47.80 \\
\hline
\end{tabular}

Q38c: The securities arbitration process is conducted by the arbitrators in a way that is economical

\begin{tabular}{|l|l|l|l|l|}
\hline $\begin{array}{l}\text { Percentage of survey participants } \\
\text { who answered this question }\end{array}$ & Agree & $\begin{array}{l}\text { Neither agree nor } \\
\text { disagree }\end{array}$ & Disagree & $\begin{array}{l}\text { Do Not } \\
\text { Know }^{65}\end{array}$ \\
\hline Northeast & 31.65 & 16.85 & 39.51 & 11.99 \\
\hline Southeast & 37.15 & 18.13 & 37.5 & 7.22 \\
\hline Midwest & 32.03 & 20.9 & 36.33 & 10.74 \\
\hline West & 40.54 & 19.24 & 33.39 & 6.84 \\
\hline
\end{tabular}

Q38d: The securities arbitration process is conducted by the arbitrators in a way that is without bias

\begin{tabular}{|l|l|l|l|l|}
\hline $\begin{array}{l}\text { Percentage of survey participants } \\
\text { who answered this question }\end{array}$ & Agree & $\begin{array}{l}\text { Neither agree nor } \\
\text { disagree }\end{array}$ & Disagree & $\begin{array}{l}\text { Do Not } \\
\text { Know }^{66}\end{array}$ \\
\hline Northeast & 29.43 & 14.53 & 41.32 & 14.72 \\
\hline Southeast & 34.44 & 11.19 & 46.5 & 7.87 \\
\hline Midwest & 29.1 & 15.23 & 45.7 & 9.96 \\
\hline West & 35.35 & 12.58 & 43.47 & 8.6 \\
\hline
\end{tabular}

\footnotetext{
${ }^{65}$ We report "do not know" responses for this question because they were above the minimum threshold of $5 \%$.
} 


\section{VI.}

\section{CONCLUSION}

This survey gathered a wealth of useful data that adds to the current understanding of participants' perceptions of the fairness of securities arbitration. Our analysis of the data indicates that, overall, survey participants' perceptions of securities arbitration are nuanced, complex and resist summary categorization. It also indicates that individual investors (customers) have more negative views about securities arbitration and less knowledge about the arbitration process than other categories of arbitration participants.

Additionally, customers' overall perceptions of the fairness of the securities arbitration process are more negative than many of their perceptions based on their most recent arbitration experience. ${ }^{67}$ Significantly, however, even with respect to questions about their most recent arbitration experience, customers responded more negatively when asked to agree or disagree with statements that are more impressionistic. ${ }^{6}$

A myriad of factors, unrelated to the fairness of the arbitration process, could explain customers' perceptions. Thus, these empirical findings shed light on subjective perceptions by arbitration participants and do not address objective standards of substantive or procedural fairness. They are important, nonetheless, because participants' perceptions of fairness, particularly procedural fairness, are critical to the integrity of the dispute resolution process. ${ }^{69}$

We recommend that SICA utilize these findings to inform its efforts to improve the securities arbitration process for all participants. We would welcome the opportunity to conduct more complex analysis of the data if SICA wishes to devote additional resources to the project.

\footnotetext{
${ }^{66}$ We report "do not know" responses for this question because they were above the minimum threshold of $5 \%$.

${ }^{67}$ Compare the level of agreement with statements in questions $38 \mathrm{~b}$ ("The securities arbitration process is conducted by the arbitrators in a way that is fair to all parties involved") and $38 \mathrm{~d}$ ("The securities arbitration process is conducted by the arbitrators in a way that is without bias") with the level of agreements with statements in questions $16,17,18,19,20,21,22,23,24,25,26$, and 31 (e.g., "The arbitration panel appeared competent to resolve the dispute"; "The arbitration panel did not understand the issues involved in the case"; "The arbitration panel was impartial"; "At the hearing, the arbitration panel listened to the parties, their representatives and their witnesses").

${ }^{68}$ See, e.g., Reactions to statements such as "I am satisfied with the outcome" (question 27), "I have a favorable view of securities arbitration for customer disputes" (question 33), and, "As a whole, I feel that the arbitration process was fair" (question 34).

${ }^{69}$ See supra notes 24-29 and accompanying text. Indeed, our finding that survey participants have positive perceptions of SRO arbitration procedures yet negative perceptions of the outcome may require rethinking the premise of the procedural justice literature that procedural fairness defines substantive fairness.
} 


\section{APPENDIX A}

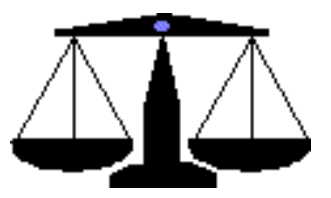

\section{SICA}

Securities Industry

Conference on

Date

Arbitration

«PREFIX» «FIRST_NAME» «MIDDLE_NAME» «LAST_NAME»

«TITLE»

«COMPANY»

«ADDRESS_1»

«ADDRESS_2»

«ITY», «STATE_PROVINCE» «ZIP»

\section{RE: Securities Arbitration Fairness Survey - 2007}

Dear «PREFIX» «LAST_NAME»:

Over the past twenty years, arbitration has become the primary method of resolving disputes in the securities industry. Recently, a report to the Securities and Exchange Commission (SEC) recommended independent research to evaluate the fairness of securities arbitration.

The Securities Industry Conference on Arbitration (SICA), a group created with the encouragement of the SEC and made up of representatives of securities regulators, the securities industry and public investors, has commissioned the Pace Investor Rights Project (affiliated with Pace University School of Law) to conduct a survey to evaluate the fairness of the arbitration of customer claims at both NASD Dispute Resolution, Inc. ("NASD") and the New York Stock Exchange ("NYSE"). This survey has been developed with our input and support, and will be administered through Cornell University's Survey Research Institute. Our mission is to study whether participants believe the securities arbitration process is conducted simply, fairly, economically and without bias by the arbitrators.

We need YOUR participation and feedback. You are receiving this survey because NASD or NYSE records show that you were involved in a dispute that was filed for arbitration in its forum in the last five years. Please take a few minutes to complete the questionnaire below and return it in the self-addressed postage-paid return envelope provided. Please be assured that 
your responses will be kept completely confidential and will never be used in any way to permit identification of you. Your responses will be used only in aggregate form. We hope that you will complete and return it as soon as possible.

We greatly appreciate your cooperation. If you have any questions, please do not hesitate to call the Survey Research Institute at 1-888-367-8404.

\section{Sincerely,}

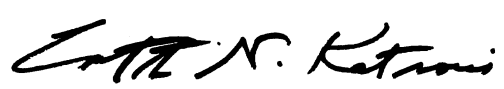

Constantine N. Katsoris 


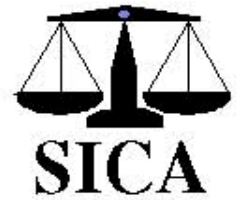

Securities Industry Conference on Arbitration

\section{SECURITIES ARBITRATION FAIRNESS SURVEY 2007}

The Pace Investor Rights Project (affiliated with Pace University School of Law) is conducting this survey for the Securities Industry Conference on Arbitration (SICA), a group created with the encouragement of the United States Securities and Exchange Commission and made up of representatives of securities regulators, the Securities Industry Association and public investors.

The purpose of this survey is to evaluate the faimess of the arbitration of customer claims at both NASD Dispute Resolution, Inc. ("NASD") and the New York Stock Exchange ("NYSE"). Our mission is to study whether participants believe the securities arbitration process is conducted simply, fairly, economically and without bias by the arbitrators. We need YOUR participation and feedback to accomplish this mission.

You are receiving this questionnaire because NASD or NYSE records show that you were involved in a dispute between a customer and a brokerage firm and/or its registered representative(s) ("associated person(s)") filed for arbitration in its forum in the last five years. Please take a few minutes to complete the questionnaire below and return it in the self-addressed postage-paid return envelope provided. Please be assured that your responses will be kept completely confidential and will never be used in any way to permit identification of you. Your responses will be used only in aggregate form.

If you have been involved in more than one such dispute in the last five years, please answer the questions below by focusing on the MOST RECENT dispute that resulted in an arbitration award following a live or paper hearing. 


\section{General Instructions}

\section{PLEASE READ THESE INSTRUCTIONS CAREFULLY}

- Please fill in the oval next to your answer completely using blue or black ink.

Example: Fill in ovals completely, like this:

Not like this: $\varnothing \quad$ Or this:

- Please follow any instructions that direct you to the next question.

\section{Example: $\bigcirc$ No $\rightarrow$ Go to Question 3.}

- If you mark an answer with a line after it, please write the specific information on the line.

Example:

Other, please specify: paper case

- Mark only one response for each question, unless other instructions are given.

1. In the past five years, have you been involved in a dispute between a customer and a securities brokerage firm and/or its registered representative(s) ("associated person(s)") that was filed for arbitration before NASD or the NYSE?

O Yes, I was involved as a customer. $\rightarrow$ Go to Question 2.

- Yes, I was involved as a corporate representative of a securities brokerage firm. $\rightarrow$ Go to Question 2.

$\circ$ Yes, I was involved as an associated person of a brokerage firm. $\rightarrow$ Go to Question 2.

○ Yes, I was involved as a lawyer or other representative of a party. $\rightarrow$ Go to Question 3.

$\circ$ No, I was not involved in any such dispute. $\rightarrow$ STOP. Do not continue with this survey, but please mail it back in postage paid envelope.

2. Were you represented by a lawyer in that dispute? (If you were involved in more than one such dispute, answer with respect to the most recent one.)

O Yes, I was represented by a lawyer.

O Yes, I was represented by a lawyer through a law school clinic.

O No, I chose to represent myself because I did not want to be represented.

o No, I represented myself because I could not afford to retain a lawyer.

O No, I represented myself because I could not find a lawyer to represent me.

○ No, I was represented by a non-lawyer.

For those who answered Question 2, please go to Question 5. 
3. (Lawyers/Representatives only) In the past five years, how many disputes between a customer and a securities brokerage firm and/or its registered representative(s) ("associated person(s)") that were

filed for arbitration before NASD or the NYSE were you involved in?

O I have been involved in only one such dispute, and I represented (select all that apply):

O the customer.

o the brokerage firm.

O the associated person.

Go to Question 6a.

O I have been involved in more than one such dispute.

4a. Overall, in the past five years, have you primarily represented customers or securities industry parties in these disputes?

o I primarily represented customers.

- I primarily represented registered representatives/"associated persons."

O I primarily represented the brokerage firm.

o Do not know/Do not recall

4b. In the most recent of these disputes, whom did you represent (select all that apply)?

o The customer

The brokerage firm

o The associated person

5. In the past five years, how many of these disputes have you been involved in?

o One

o 2 to 5

O 6 to 10

O More than 10

O Do not know/Do not recall

6a. Did the customer agreement in the most recent dispute contain a clause requiring the parties to resolve that dispute through arbitration?

$\circ$ Yes $\rightarrow$ Go to Question 6b.

$\circ \mathrm{No} \rightarrow$ Go to Question 7 .

○ Do not know/Do not recall $\rightarrow$ Go to Question 7.

6b. Were you aware before the dispute arose that the customer agreement contained an arbitration clause?

O Yes

O No

O Do not know/Do not recall

7. What was the primary reason this dispute was filed in an arbitration forum?

○ Believed arbitration would be faster than court.

- Believed arbitration would be less expensive than court.

- Believed arbitration would be more fair than court.

O Believed arbitration would provide a larger recovery than court.

- Believed arbitration was required.

o Preferred arbitration for other reasons.

O A lawyer recommended it.

O Did not initiate the claim.

o Do not know/Do not recall 
8. Before the most recent dispute was filed in arbitration, did you have concerns about the securities arbitration forum? (select all that apply)

o No, I had no concerns.

- Yes, I was concerned that it would be expensive.

○ Yes, I was concerned that it would be a slow process.

O Yes, I was concerned that it would not be a fair process.

O Yes, I was concerned about the composition of the arbitration panel.

○ Yes, I was concerned that the arbitrators would be biased.

O Yes, Ihad other concerns.

O I do not recall if I had any concerns.

9. With respect to your most recent dispute, in what state was the hearing scheduled to take place? (If the dispute was a Simplified Arbitration that took place on the papers, write "paper case.")

10. What was the approximate amount of damages (excluding punitive damages, attorneys' fees, interest and costs) claimed in this most recent dispute?

O Not exceeding $\$ 25,000$

○ $\$ 25,001-\$ 50,000$

○ $\$ 50,001-\$ 100,000$

○ $\$ 101,000-\$ 250,000$

○ $\$ 250,001-\$ 1,000,000$

O More than $\$ 1,000,000$

○ Do not know/Do not recall

11. How was this most recent dispute resolved?

The arbitration panel issued an award of damages to the customer after a live hearing.

- The arbitration panel issued an award of damages to the customer based on written submissions (a "paper"case).

O The claimant voluntarily withdrew the claim.

The parties settled the claim on their own.

T The parties settled the claim with the aid of a mediator.

- The arbitration panel did not award damages to the customer based on written submissions (a "paper"case).

- The arbitration panel dismissed the case before a live hearing began.

- The arbitration panel did not award damages to the customer after a live hearing.

o Do not know/Do not recall

12a. What was the approximate amount of the total award in this most recent dispute?

○ $\$ 1.00-10,000$

○ $\$ 10,001-50,000$

○ $\$ 50,001-250,000$

○ $\$ 250,001-1,000,000$

O More than $\$ 1,000,000$

o Do not know/Do not recall 
12b. What percentage of damages (excluding punitive damages, attorneys' fees, interest and costs) originally claimed does this represent?

o Less than 1

o 1-10

○ 50-74

○ $11-25$

○ $75-99$

○ $26-49$

○ 100

○ Do not know/Do not recall

13. How many arbitrators were appointed to decide this dispute?

$\circ$ Three $\rightarrow$ Go to Question 14a.

o One $\rightarrow$ Go to Question 15.

○ No arbitrators were appointed. $\rightarrow$ Go to Question 16.

○ Do not know/Do not recall $\rightarrow$ Go to Question 16.

14a. Did you know, prior to the filing of the arbitration, that one arbitrator would be connected in some way with the securities industry (an "industry arbitrator")?

$\circ$ Yes

$\circ$ No

○ Do not recall

14b. Did you know, at any time during the dispute, which arbitrator was the industry arbitrator and which arbitrators were public arbitrators?

$\circ$ Yes

○ No

○ Do not recall

14c. Would you say that the performance of the industry arbitrator and the public arbitrators was different?

O Yes

O No

O There was no opportunity to assess the performance of the arbitrators.

○ Do not know/Do not recall

14d. Would you say that the industry arbitrator favored one side over the other at any time during the dispute?

○ No

- Yes, the industry arbitrator favored the customer.

$\circ$ Yes, the industry arbitrator favored at least one securities industry party.

There was no opportunity to assess whether the arbitrators favored any party.

o Do not know/Do not recall

14e. Was the award unanimous?

O Yes

$\circ$ No

O Do not know/Do not recall 
15. Would you say that any public arbitrator favored one side over the other at any time during the dispute?

○ No

- Yes, a public arbitrator favored the customer.

- Yes, a public arbitrator favored at least one securities industry party.

O There was no opportunity to assess whether the arbitrator favored any party.

o Do not know/Do not recall

Based on your experiences in the MOST RECENT dispute in which you were involved that was filed for arbitration before NASD or the NYSE, please indicate the extent to which you agree or disagree with the following statements. If your dispute did not progress enough to enable you to evaluate the statement, select "Not Applicable." Please answer these questions, to the extent they apply, even if your dispute did not progress to a hearing.

16. The arbitration panel appeared competent to
resolve the dispute.

17. The arbitration panel did not understand the issues involved in the case.

18. The arbitration panel was open-minded.

19. The arbitration panel was impartial.

20. The arbitration panel appeared competent to resolve pre-hearing issues.

21. The discovery process enabled me to obtain the information needed for a hearing.

22. The arbitration hearings took too long.

23. At the hearing, the arbitration panel listened to the parties, their representatives and their witnesses.

24. At the hearing, the arbitration panel understood the legal arguments in the case.

25. At the hearing, the arbitration panel did not provide a sufficient amount of time for the parties to present their evidence.

26. At the hearing, the arbitration panel did not provide a sufficient amount of time for the parties to argue the merits of their case.

27. I am satisfied with the outcome.

28. I would be more satisfied if I had an explanation of the award.

29. The outcome was not very different from my initial expectations.

30. The arbitration process was too expensive.

31. The arbitration panel did not apply the law to decide the dispute.

32. I would recommend to others that they use arbitration to resolve their securities disputes.

33. I have a favorable view of securities arbitration for customer disputes.

34. As a whole, I feel that the arbitration process was fair.

\begin{tabular}{|c|c|c|c|c|c|c|}
\hline $\begin{array}{c}\text { Strongly } \\
\text { Agree }\end{array}$ & Agree & \begin{tabular}{|c|} 
Neither \\
Agree nor \\
Disagree
\end{tabular} & Disagree & $\begin{array}{l}\text { Strongly } \\
\text { Disagree }\end{array}$ & $\begin{array}{c}\text { Not } \\
\text { Applicable }\end{array}$ & $\begin{array}{l}\text { Don't } \\
\text { Know }\end{array}$ \\
\hline 0 & 0 & 0 & 0 & 0 & 0 & 0 \\
\hline 0 & 0 & 0 & 0 & 0 & 0 & 0 \\
\hline 0 & 0 & 0 & 0 & 0 & 0 & 0 \\
\hline 0 & 0 & 0 & 0 & 0 & 0 & 0 \\
\hline 0 & 0 & 0 & 0 & 0 & 0 & 0 \\
\hline 0 & 0 & 0 & 0 & 0 & 0 & 0 \\
\hline 0 & 0 & 0 & 0 & 0 & 0 & 0 \\
\hline 0 & 0 & 0 & 0 & 0 & 0 & 0 \\
\hline 0 & 0 & 0 & 0 & 0 & 0 & 0 \\
\hline 0 & 0 & 0 & 0 & 0 & 0 & 0 \\
\hline 0 & 0 & 0 & 0 & 0 & 0 & 0 \\
\hline 0 & 0 & 0 & 0 & 0 & 0 & 0 \\
\hline 0 & 0 & 0 & 0 & 0 & 0 & 0 \\
\hline 0 & 0 & 0 & 0 & 0 & 0 & 0 \\
\hline 0 & 0 & 0 & 0 & 0 & 0 & 0 \\
\hline 0 & 0 & 0 & 0 & 0 & 0 & 0 \\
\hline 0 & 0 & 0 & 0 & 0 & 0 & 0 \\
\hline 0 & 0 & 0 & 0 & 0 & 0 & 0 \\
\hline 0 & 0 & 0 & 0 & 0 & 0 & 0 \\
\hline
\end{tabular}


35. In the last five years, have you ever been a party or represented a party in at least one civil court case (not involving a criminal, matrimonial or custodial matter and excluding class action lawsuits)? (select all that apply)

$\circ$ No $\rightarrow$ Go to Question 36.

$\circ$ Yes, I was a plaintiff.

○ Yes, Irepresented a plaintiff.

$\circ$ Yes, I was a defendant.

○ Yes, I represented a defendant.

o Do not know/Do not recall

35a. Focusing on your most recent experience in a civil court case, how different do you think your result from the arbitration would have been had it proceeded in court?

○ Verydifferent

$\circ$ A little different

O Exactly the same

O Do not know

35b. As compared to your most recent experience in a civil court case, how fair is securities arbitration?

$\circ$ Very fair

O Somewhat fair

O Equally fair

O Somewhat unfair

$\circ$ Very Unfair

○ Do not know

36. Based on your experiences in one or more securities arbitration customer disputes, if you had the choice, would you choose arbitration to resolve a customer dispute in the future? (select all that apply)

- Yes, I would choose arbitration over court.

O No, I would not choose arbitration because the process is not fair.

O No, I would not choose arbitration because the process is more expensive than court.

O No, I would not choose arbitration because the process takes more time than court.

○ No, I would not choose arbitration because the arbitrators are not competent to resolve customer-broker disputes.

o I'm not sure.

O None of the above.

37. Are you familiar with changes that the securities arbitration forums have made to their procedural rules in the last five years?

O Yes, I think the changes have made the process fairer.

O Yes, I think the changes have not made a difference.

Y Yes, I think the changes have made the process less fair.

No, I am not familiar with the changes. 


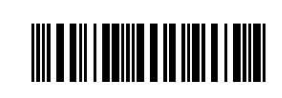

38. Please indicate the extent to which you agree or disagree with the following statements.

In your opinion, do you believe that the securities arbitration process is conducted by the arbitrators in a way that is:

\begin{tabular}{|c|c|c|c|c|c|c|}
\hline & $\begin{array}{c}\text { Strongly } \\
\text { Agree }\end{array}$ & Agree & $\begin{array}{l}\text { Neither } \\
\text { Agree } \\
\text { nor } \\
\text { Disagree }\end{array}$ & Disagree & $\begin{array}{l}\text { Strongly } \\
\text { Disagree }\end{array}$ & $\begin{array}{l}\text { Don't } \\
\text { Know }\end{array}$ \\
\hline a. simple for all parties involved & 0 & 0 & $\circ$ & 0 & 0 & 0 \\
\hline b. fair to all parties involved & 0 & 0 & 0 & 0 & 0 & 0 \\
\hline c. economical & ○ & o & 0 & 0 & 0 & 0 \\
\hline d. without bias & o & 0 & 0 & 0 & 0 & 0 \\
\hline
\end{tabular}

\section{THANK YOU FOR YOUR PARTICIPATION!}

Please return this survey in the postage-paid envelope provided, or mail it to:

Survey Research Institute

Cornell University

391 Pine Tree Rd., Rm. 118

Ithaca, NY 14850 


\section{APPENDIX B}

TEST RUN: UNWEIGHTED RESPONSES VS. WEIGHTED RESPONSES

QUESTIONS 19, 34, 38A, 38B, 38c, 38D

\begin{tabular}{|c|c|c|c|c|c|c|}
\hline Question & $\begin{array}{l}\text { Strongly } \\
\text { Agree }\end{array}$ & Agree & $\begin{array}{l}\text { Neither } \\
\text { Agree Nor } \\
\text { Disagree }\end{array}$ & Disagree & $\begin{array}{l}\text { Strongly } \\
\text { Disagree }\end{array}$ & $\begin{array}{l}\text { Do Not } \\
\text { Know }\end{array}$ \\
\hline $\begin{array}{l}\text { Q19-Weighted } \\
\text { combined }\end{array}$ & 40.94 & & 14.3 & & 33.86 & 10.9 \\
\hline $\begin{array}{l}\text { Q19- } \\
\text { Unweighted } \\
\text { combined }\end{array}$ & 38.1 & & 14.2 & & 35.1 & 12.6 \\
\hline $\begin{array}{l}\text { Q19-Weighted } \\
\text { "everyone } \\
\text { else" }\end{array}$ & 47.98 & & 14.66 & & 30.92 & 6.43 \\
\hline $\begin{array}{l}\text { Q19- } \\
\text { Unweighted } \\
\text { "everyone } \\
\text { else" }\end{array}$ & 47.82 & & 14.59 & & 31.25 & 6.34 \\
\hline $\begin{array}{l}\text { Q34-Weighted } \\
\text { combined }\end{array}$ & 42.33 & & 8.95 & & 45.49 & 3.22 \\
\hline $\begin{array}{l}\text { Q34- } \\
\text { Unweighted } \\
\text { combined }\end{array}$ & 39.4 & & 9 & & 47.9 & 3.7 \\
\hline $\begin{array}{l}\text { Q34-Weighted } \\
\text { "everyone } \\
\text { else" }\end{array}$ & 50.66 & & 9.13 & & 40.21 & \\
\hline $\begin{array}{l}\text { Q34- } \\
\text { Unweighted } \\
\text { "everyone } \\
\text { else" }\end{array}$ & 50.64 & & 9.23 & & 40.13 & \\
\hline $\begin{array}{l}\text { Q38a- } \\
\text { Weighted } \\
\text { combined }\end{array}$ & 10.12 & 35.31 & 16.54 & 19.40 & 12.15 & 6.48 \\
\hline $\begin{array}{l}\text { Q38a- } \\
\text { Unweighted } \\
\text { combined }\end{array}$ & 9.3 & 33.6 & 16.3 & 19.6 & 13.5 & 7.6 \\
\hline $\begin{array}{l}\text { Q38a- } \\
\text { Weighted } \\
\text { "everyone } \\
\text { else" }\end{array}$ & 53.71 & & 17.65 & & 28.64 & \\
\hline $\begin{array}{l}\text { Q38a- } \\
\text { Unweighted } \\
\text { "everyone } \\
\text { else" }\end{array}$ & 53.6 & & 17.6 & & 28.9 & \\
\hline
\end{tabular}




\begin{tabular}{|c|c|c|c|c|c|c|}
\hline $\begin{array}{l}\text { Q38b- } \\
\text { Weighted } \\
\text { combined }\end{array}$ & 10.72 & 25.53 & 11.23 & 20.05 & 25.71 & 6.76 \\
\hline $\begin{array}{l}\text { Q38b- } \\
\text { Unweighted } \\
\text { combined }\end{array}$ & 9.8 & 23.7 & 11.3 & 20.0 & 27.2 & 8.0 \\
\hline $\begin{array}{l}\text { Q38b- } \\
\text { Weighted } \\
\text { "everyone } \\
\text { else" }\end{array}$ & 45.01 & & 11.18 & & 43.81 & \\
\hline $\begin{array}{l}\text { Q38b- } \\
\text { Unweighted } \\
\text { "everyone } \\
\text { else" }\end{array}$ & 43.9 & & 11.1 & & 45.0 & \\
\hline $\begin{array}{l}\text { Q38c- } \\
\text { Weighted } \\
\text { combined }\end{array}$ & 8.11 & 29.25 & 18.61 & 20.73 & 14.32 & 9.89 \\
\hline $\begin{array}{l}\text { Q38c- } \\
\text { Unweighted } \\
\text { combined }\end{array}$ & 7.6 & 28.0 & 18.9 & 20.8 & 14.8 & 9.9 \\
\hline $\begin{array}{l}\text { Q38c- } \\
\text { Weighted } \\
\text { "everyone } \\
\text { else" }\end{array}$ & 41.83 & & 18.08 & & 34.24 & 5.85 \\
\hline $\begin{array}{l}\text { Q38c- } \\
\text { Unweighted } \\
\text { "everyone } \\
\text { else" }\end{array}$ & 41.7 & & 18.3 & & 34.8 & 5.3 \\
\hline $\begin{array}{l}\text { Q38d- } \\
\text { Weighted } \\
\text { combined }\end{array}$ & 10.92 & 22.45 & 13.28 & 19.17 & 24.23 & 9.94 \\
\hline $\begin{array}{l}\text { Q38d- } \\
\text { Unweighted } \\
\text { combined }\end{array}$ & 9.8 & 20.8 & 13.2 & 18.7 & 25.9 & 11.6 \\
\hline $\begin{array}{l}\text { Q38d- } \\
\text { Weighted } \\
\text { "everyone } \\
\text { else" }\end{array}$ & 40.24 & & 13.55 & & 40.62 & 5.59 \\
\hline $\begin{array}{l}\text { Q38d- } \\
\text { Unweighted } \\
\text { "everyone } \\
\text { else" }\end{array}$ & 40.2 & & 13.7 & & 40.9 & 5.3 \\
\hline
\end{tabular}

